Prepared in cooperation with the Johnson County Stormwater Management Program

\title{
Quality of Streams in Johnson County, Kansas, and Relations to Environmental Variables, 2003-07
}

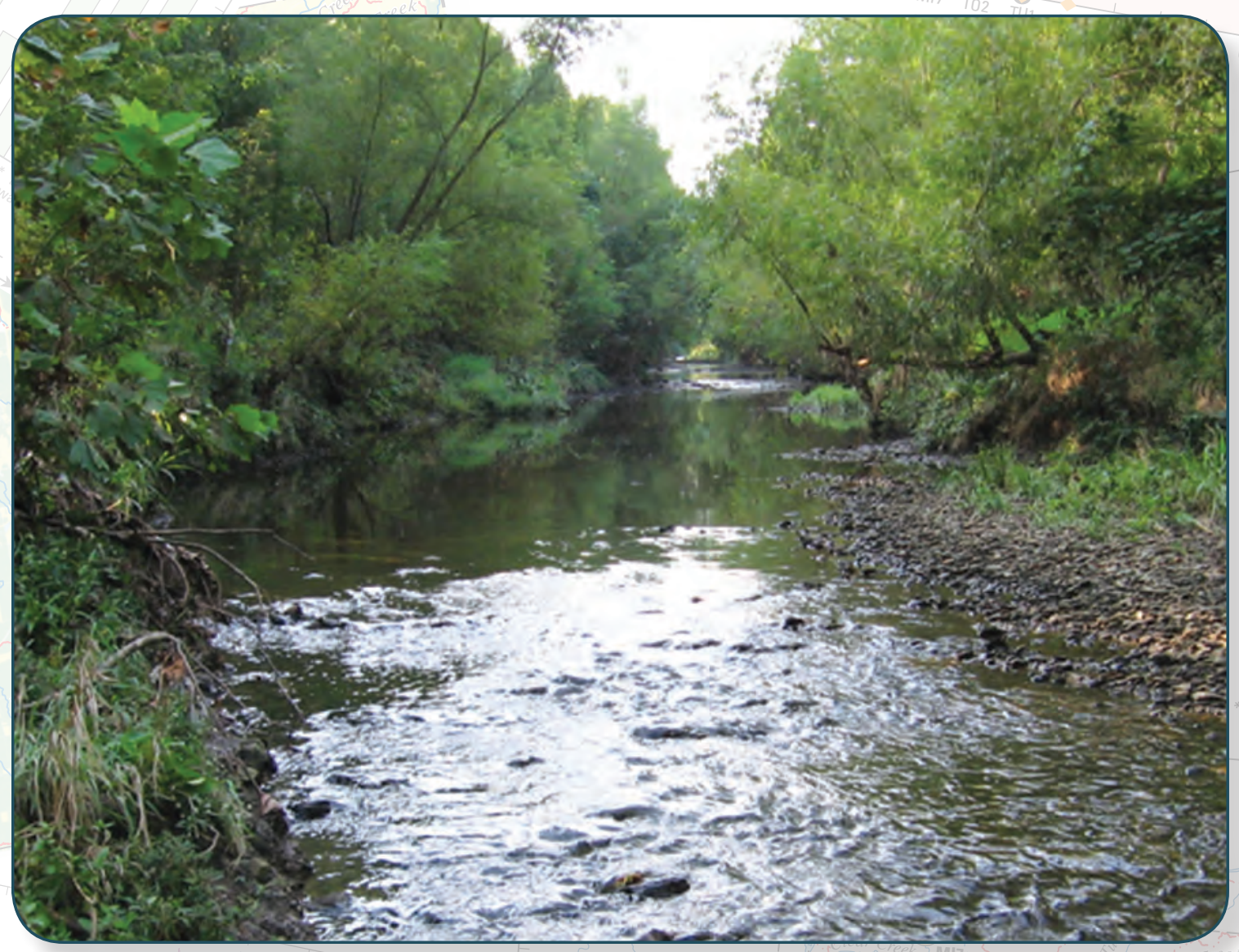

Scientific Investigations Report 2009-5235

U.S. Department of the Interior U.S. Geological Survey 
Cover photograph: Indian Creek near Highway 69 in Johnson County, Kansas, September 2007, taken by Barry Poulton, USGS, Columbia, MO. 


\section{Quality of Streams in Johnson County, Kansas, and Relations to Environmental Variables, 2003-07}

By Teresa J. Rasmussen, Barry C. Poulton, and Jennifer L. Graham

Prepared in cooperation with the Johnson County Stormwater Management Program

Scientific Investigations Report 2009-5235 


\title{
U.S. Department of the Interior \\ KEN SALAZAR, Secretary \\ U.S. Geological Survey \\ Marcia K. McNutt, Director
}

\section{U.S. Geological Survey, Reston, Virginia: 2009}

\author{
For more information on the USGS — the Federal source for science about the Earth, its natural and living resources, \\ natural hazards, and the environment, visit http://www.usgs.gov or call 1-888-ASK-USGS \\ For an overview of USGS information products, including maps, imagery, and publications, \\ visit http://www.usgs.gov/pubprod \\ To order this and other USGS information products, visit http://store.usgs.gov
}

Any use of trade, product, or firm names is for descriptive purposes only and does not imply endorsement by the U.S. Government.

Although this report is in the public domain, permission must be secured from the individual copyright owners to reproduce any copyrighted materials contained within this report.

Suggested citation:

Rasmussen, T.J., Poulton, B.C., and Graham, J.L., 2009, Quality of streams in Johnson County, Kansas, and relations to environmental variables, 2003-07: U.S. Geological Survey Scientific Investigations Report 2009-5235, 84p. with appendices. 


\section{Contents}

Abstract

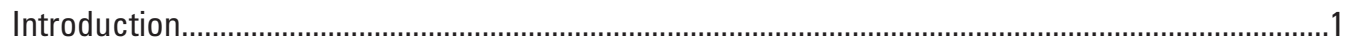

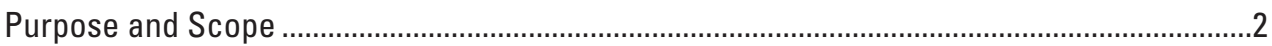

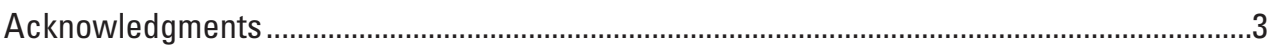

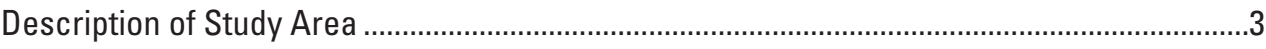

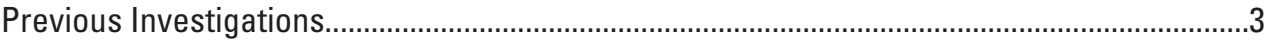

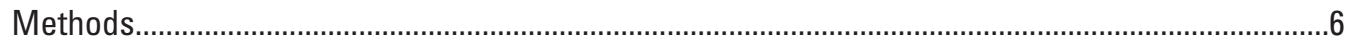

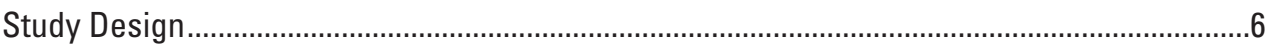

Data Collection ........................................................................................................................

Stream-Water and Streambed-Sediment Sampling ......................................................

Watershed Variables -- Land Use, Streamflow, Precipitation .........................................6

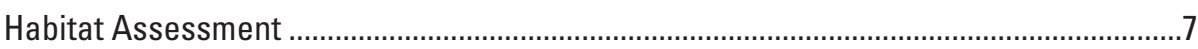

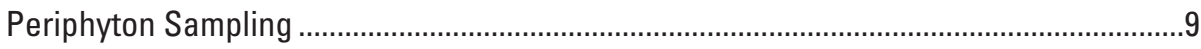

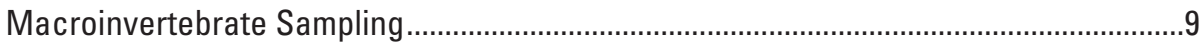

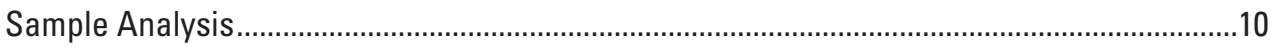

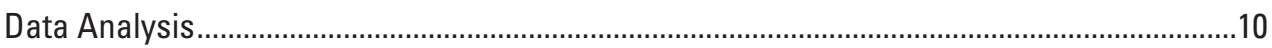

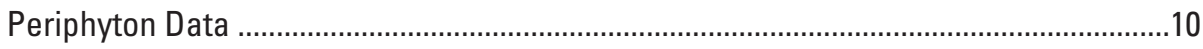

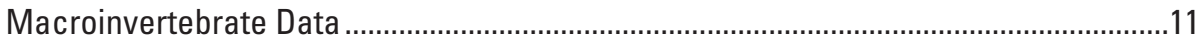

Relating Biological Data to Environmental Variables ......................................................12

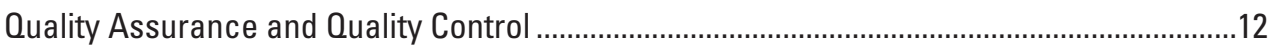

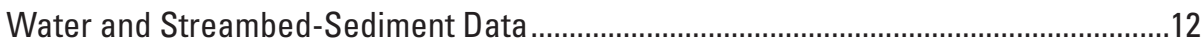

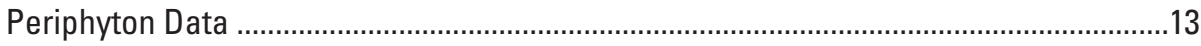

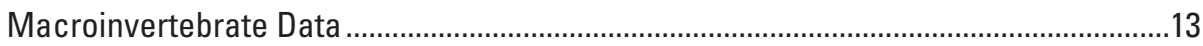

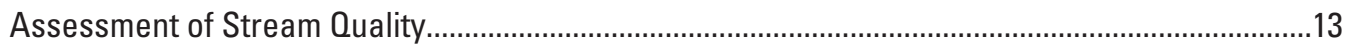

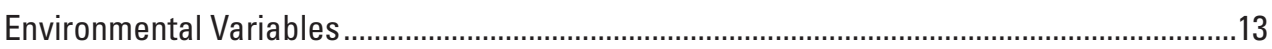

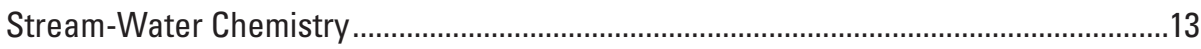

Streambed-Sediment Chemistry ................................................................................14

Watershed Variables-Streamflow and Precipitation ...................................................15

Habitat

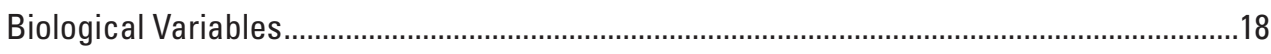

Periphyton Communities.................................................................................................

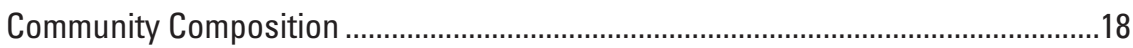

Periphyton Chlorophyll Concentrations, Abundance, and Biovolume.....................20

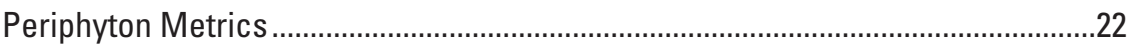

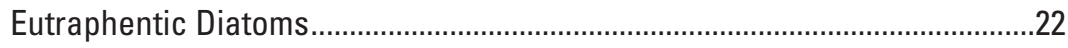

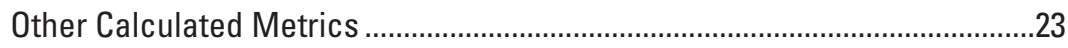

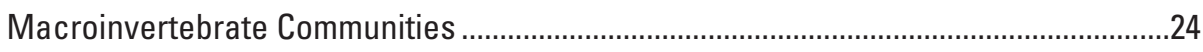

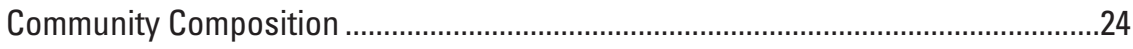

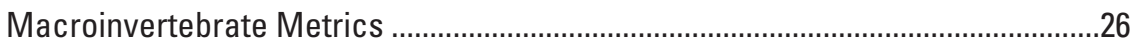

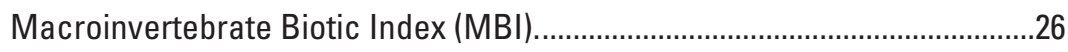

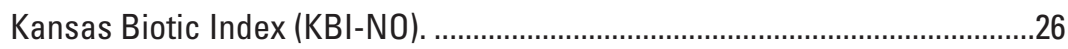

EPT Taxa Richness (EPTRich) ...................................................................26

Percentage of EPT (\%EPT) ......................................................................... 
Total Taxa Richness (TRich). ..........................................................................26

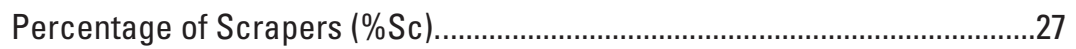

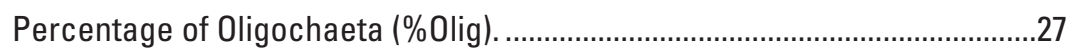

Percentage of Tanytarsini (\%Tany).....................................................................27

Percentage of Intolerant Organisms, KBI-NO<3 (\%Int-KBI) ..........................27

Percentage of Ephemeroptera and Plecoptera (\%EP).......................................27

Shannon Diversity Index (SDI)........................................................................27

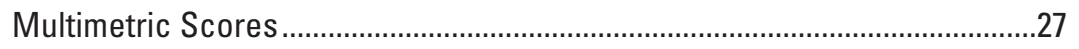

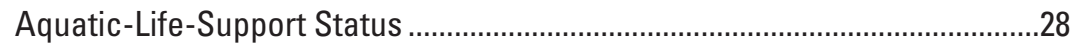

Relations Between Stream Quality and Environmental Variables.........................................31

Biological Responses to Environmental Variables.................................................................3

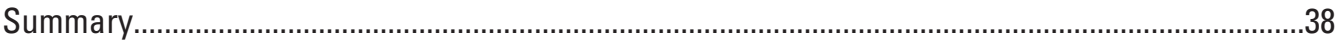

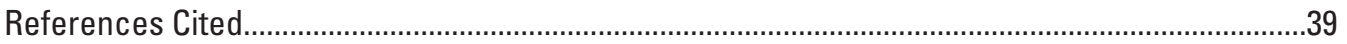

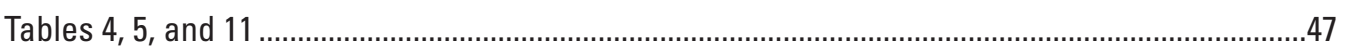

Appendices 1-7

\section{Figures}

1. Map showing location of biological sampling sites, selected municipal wastewater treatment facilities, and urban and rural land use in Johnson County, Kansas, 2007 ......4

2. Photographs showing data collection activities at biological sampling sites in Johnson County, Kansas, 2007, including (A) collecting a water sample for chemical analysis, $(B)$ conducting a habitat assessment, $(C)$ scraping periphyton from streambed rocks, and $(D)$ using a kicknet to collect macroinvertebrates

3-7. Graphs showing:

3. Streamflow, specific conductance, water temperature, dissolved oxygen, turbidity, and precipitation prior to collection of samples from downstream Mill Creek site MI7 in Johnson County, Kansas, January 1-April 1, 2007.

4. Mean daily streamflow in the Blue River and Indian Creek in Johnson County, Kansas, prior to collection of samples in 2003, 2004, and 2007.

5. Algal periphyton $(A)$ chlorophyll concentrations, $(B)$ abundance, and $(C)$ biovolume at biological sampling sites in Johnson County, Kansas, March and July 2007.

6. Percentage of algal periphyton biovolume composed of eutraphentic diatoms at biological sampling sites in Johnson County, Kansas (table 1), March and July 2007.

7. Ten-metric macroinvertebrate scores for biological sampling sites in Johnson County, Kansas (table 1), 2003, 2004, and 2007

8. Map showing relative biological effects from human disturbance as indicated by 10-metric macroinvertebrate scores for biological sampling sites in Johnson County, Kansas, 2003, 2004, and 2007

9-11. Graphs showing:

9. Kansas Department of Health and Environment aquatic-life-support status for biological sampling sites in Johnson County, Kansas (table 1), 2003, 2004, and 2007

10. Linear relations between selected stream quality and watershed variables at biological sampling sites in Johnson County, Kansas, 2007.

11. Multidimensional scaling (MDS) of biological communities at 20 biological sampling sites in Johnson County, Kansas, 2007. 


\section{Tables}

1. Location and description of biological sampling sites in Johnson County, Kansas, 2007 including estimated watershed area and approximate upstream land use

2. Summary of streamflow metrics used in analyses of biological and water-quality data for streams in Johnson County, Kansas, 2007

3. List of macroinvertebrate metrics, abbreviations, and references used for assessment of biological conditions at biological sampling sites in Johnson County, Kansas, 2007

4. Results of analysis of physical properties, dissolved solids, major ions, nutrients, trace elements, suspended sediment, fecal-indicator bacteria, and organic compounds in water from biological sampling sites in Johnson County, Kansas, March 2007.

5. Results of analysis of carbon, nutrients, trace elements, and organic compounds in streambed-sediment samples from biological sampling sites in Johnson County, Kansas, March, 2007

6. Streamflow statistics used in correlation analysis for biological sampling sites in Johnson County, Kansas, 2005-07

7. Results of habitat assessment at biological sampling sites in Johnson County, Kansas, 2007

8. Percentage contributions of each algal periphyton division to total abundance and biovolume at biological sampling sites in Johnson County, Kansas, March and July 2007

9. Algal periphyton chlorophyll concentrations, abundance, and biovolume at biological sampling sites in Johnson County, Kansas, March and July 2007.

10. Percentage contributions of diatom indicator taxa or groups of diatom indicator taxa to total periphyton biovolume at selected biological sampling sites in Johnson County, Kansas, March and July 2007.

11. Macroinvertebrate metric values, 10-metric scores, and aquatic-life-support values for biological sampling sites in Johnson County, Kansas, 2003, 2004, and 2007.

12. Criteria for four macroinvertebrate metrics used in Kansas to evaluate aquatic-lifesupport status of streams

13. Spearman correlation matrix for water and streambed-sediment chemistry, land use, streamflow, habitat, and macroinvertebrate variables at biological sampling sites in Johnson County, Kansas, 2007

14. Results of principal components analysis of stream quality and watershed environmental variables at biological sampling sites in Johnson County, Kansas, 2007

\section{Appendices}

1. Habitat assessment protocol used during evaluation of stream quality in Johnson County, Kansas, 2007

2. Periphyton taxa identified and the number of biological sampling sites where each taxa occurred in Johnson County, Kansas, streams during March and July 2007

3. Four most dominant periphyton taxa on the basis of abundance and the percentage contribution of each taxa to total abundance at biological sampling sites in Johnson County, Kansas, during March and July 2007

4. Four most dominant periphyton taxa on the basis of biovolume and the percentage contribution of each taxa to total biovolume at biological sampling sites in Johnson County, Kansas, during March and July 2007 
5. Periphtyon metric scores calculated by the Algal Data Analysis Software (after Cuffney, 2003) for biological sampling sites in Johnson County, Kansas, during March and July 2007

6. List of macroinvertebrate taxa at biological sampling sites in Johnson County, Kansas, 2007

7. List of four most dominant macroinvertebrate taxa at biological sampling sites in Johnson County, Kansas, 2007

\section{Conversion Factors, Abbreviations, and Datums}

Inch/Pound to SI

\begin{tabular}{|c|c|c|}
\hline Multiply & By & To obtain \\
\hline \multicolumn{3}{|c|}{ Length } \\
\hline inch (in.) & 2.54 & centimeter $(\mathrm{cm})$ \\
\hline inch (in.) & 25.4 & millimeter $(\mathrm{mm})$ \\
\hline foot $(\mathrm{ft})$ & 0.3048 & meter $(\mathrm{m})$ \\
\hline $\operatorname{Meter}(\mathrm{m})$ & 3.2808 & foot (ft) \\
\hline micrometer or micron $(\mu \mathrm{m})$ & 0.00003937 & inch (in.) \\
\hline mile (mi) & 1.609 & kilometer (km) \\
\hline millimeter $(\mathrm{mm})$ & 0.0397 & inch (in.) \\
\hline \multicolumn{3}{|c|}{ Area } \\
\hline square meter $\left(\mathrm{m}^{2}\right)$ & 10.7639 & square foot $\left(\mathrm{ft}^{2}\right)$ \\
\hline square mile $\left(\mathrm{mi}^{2}\right)$ & 2.590 & square kilometer $\left(\mathrm{km}^{2}\right)$ \\
\hline \multicolumn{3}{|c|}{ Volume } \\
\hline cubic foot $\left(\mathrm{ft}^{3}\right)$ & 0.02832 & cubic meter $\left(\mathrm{m}^{3}\right)$ \\
\hline Liter (L) & 0.26417 & gallon (gal) \\
\hline milliliter (mL) & 0.0338 & ounce, fluid (oz) \\
\hline ounce, fluid (oz) & 0.02957 & liter $(\mathrm{L})$ \\
\hline \multicolumn{3}{|c|}{ Flow rate } \\
\hline cubic foot per second $\left(\mathrm{ft}^{3} / \mathrm{s}\right)$ & 0.02832 & cubic meter per second $\left(\mathrm{m}^{3} / \mathrm{s}\right)$ \\
\hline $\begin{array}{l}\text { cubic foot per second per day } \\
\qquad\left[\left(\mathrm{ft}^{3} / \mathrm{s}\right) / \mathrm{d}\right]\end{array}$ & 0.02832 & $\begin{array}{l}\text { cubic meter per second per day } \\
\qquad\left[\left(\mathrm{m}^{3} / \mathrm{s}\right) / \mathrm{d}\right]\end{array}$ \\
\hline $\begin{array}{l}\text { cubic foot per second per square mile } \\
{\left[\left(\mathrm{ft}^{3} / \mathrm{s}\right) / \mathrm{mi}^{2}\right]}\end{array}$ & 0.01093 & $\begin{array}{l}\text { cubic meter per second per } \\
\text { square kilometer }\left[\left(\mathrm{m}^{3} / \mathrm{s}\right) / \mathrm{km}^{2}\right]\end{array}$ \\
\hline foot per mile (ft/mi) & 0.1894 & meter per kilometer $(\mathrm{m} / \mathrm{km})$ \\
\hline foot per second $(\mathrm{ft} / \mathrm{s})$ & 0.3048 & meter per second $(\mathrm{m} / \mathrm{s})$ \\
\hline million gallons per day (Mgal/d) & 0.4381 & cubic meters per second $\left(\mathrm{m}^{3} / \mathrm{s}\right)$ \\
\hline
\end{tabular}

Temperature in degrees Celsius $\left({ }^{\circ} \mathrm{C}\right)$ may be converted to degrees Fahrenheit $\left({ }^{\circ} \mathrm{F}\right)$ as follows:

$$
{ }^{\circ} \mathrm{F}=\left(1.8 \times{ }^{\circ} \mathrm{C}\right)+32 .
$$

Horizontal coordinate information is referenced to the North American Datum of 1983 NAD 83). Concentrations of chemical constituents in water are given either in milligrams per liter (mg/L) or micrograms per liter $(\mu \mathrm{g} / \mathrm{L})$. 


\title{
Acronyms and Other Abbreviations Used in Report
}

\author{
ADAS Algal Data Analysis System \\ AIMS \\ Automated Information Mapping System \\ BMP best management practice \\ CV coefficient of variation \\ CWA 1972 Clean Water Act \\ EPT Ephemeroptera-Plecoptera-Trichoptera \\ EWI equal width increment \\ FNU formazin nephelometric unit \\ GIS geographic information system \\ HDPE high-density polyethylene \\ HUC hydrologic unit code \\ IDAS Invertebrate Data Analysis System \\ IHA Indicators of Hydrologic Alteration, Nature Conservancy \\ KBI-NO Kansas Biotic Index \\ KDHE Kansas Department of Health and Environment \\ MBI Macroinvertebrate Biotic Index \\ MDS multidimensional scaling \\ NAWQA National Water-Quality Assessment, U.S. Geological Survey \\ NPDES National Pollutant Discharge Elimination System \\ NWQL National Water Quality Laboratory, U.S. Geological Survey \\ PAH polycyclic aromatic hydrocarbon \\ PCA principal component analysis \\ PEC probable effects concentration \\ $\mathrm{R}^{2} \quad$ correlation coefficient \\ RHAP Rapid Habitat Assessment Protocol \\ RPD relative percentage difference
}





\title{
Quality of Streams in Johnson County, Kansas, and Relations to Environmental Variables, 2003-07
}

\author{
By Teresa J. Rasmussen'1, Barry C. Poulton², and Jennifer L. Graham¹
}

\section{Abstract}

The quality of streams and relations to environmental variables in Johnson County, northeastern Kansas, were evaluated using water, streambed sediment, land use, streamflow, habitat, algal periphyton (benthic algae), and benthic macroinvertebrate data. Water, streambed sediment, and macroinvertebrate samples were collected in March 2007 during base flow at 20 stream sites that represent 11 different watersheds in the county. In addition, algal periphyton samples were collected twice (spring and summer 2007) at one-half of the sites. Environmental data including water and streambed-sediment chemistry data (primarily nutrients, fecal-indicator bacteria, and organic wastewater compounds), land use, streamflow, and habitat data were used in statistical analyses to evaluate relations between biological conditions and variables that may affect them. This report includes an evaluation of water and streambed-sediment chemistry, assessment of habitat conditions, comparison of biological community attributes (such as composition, diversity, and abundance) among sampling sites, placement of sampling sites into impairment categories, evaluation of biological data relative to environmental variables, and evaluation of changes in biological communities and effects of urbanization. This evaluation is useful for understanding factors that affect stream quality, for improving water-quality management programs, and for documenting changing conditions over time. The information will become increasingly important for protecting streams in the future as urbanization continues.

Results of this study indicate that the biological quality at nearly all biological sampling sites in Johnson County has some level of impairment. Periphyton taxa generally were indicative of somewhat degraded conditions with small to moderate amounts of organic enrichment. Camp Branch in the Blue River watershed was the only site that met State criteria for full support of aquatic life in 2007. Since 2003, biological quality improved at one rural sampling site, possibly because of changes in wastewater affecting the site, and declined at three urban sites possibly because of the combined effects of ongoing development. Rural streams in the western and southern parts of the county, with land-use conditions similar

${ }^{1}$ U.S. Geological Survey, Water Science Center, Lawrence, Kansas.

${ }^{2}$ U.S. Geological Survey, Columbia Environmental Research Center, Columbia, Missouri. to those found at the State reference site (Captain Creek), continue to support some organisms normally associated with healthy streams.

Several environmental factors contribute to biological indicators of stream quality. The primary factor explaining biological quality at sites in Johnson County was the amount of urbanization upstream in the watershed. Specific conductance of stream water, which is a measure of dissolved solids in water and is determined primarily by the amount of groundwater contributing to streamflow, the amount of urbanization, and discharges from wastewater and industrial sites, was strongly negatively correlated with biological stream quality as indicated by macroinvertebrate metrics. Concentration of polycyclic aromatic hydrocarbons (PAHs) in streambed sediment also was negatively correlated with biological stream quality. Individual habitat variables that most commonly were positively correlated with biological indicators included stream sinuosity, buffer length, and substrate cover diversity. Riffle substrate embeddedness and sediment deposition commonly were negatively correlated with favorable metric scores. Statistical analysis indicated that specific conductance, impervious surface area (a measure of urbanization), and stream sinuosity explained 85 percent of the variance in macroinvertebrate communities.

Management practices affecting environmental variables that appear to be most important for Johnson County streams include protection of stream corridors, measures that reduce the effects of impervious surfaces associated with urbanization, reduction of dissolved solids in stream water, reduction of PAHs entering streams and accumulating in streambed sediment, improvement of buffer conditions particularly related to buffer continuity, and improvement of streambed substrate conditions by reducing sediment loads to streams. Because of the complexity of urban stream systems and connectivity of various factors affecting stream quality, improvement in any single environmental variable may not result in immediate measurable improvements in stream quality.

\section{Introduction}

Streams in Johnson County, Kansas, are affected by stormwater runoff from urban and rural watersheds, municipal wastewater and industrial discharges, and changes in 
streamflow characteristics and riparian habitat. As one of the fastest growing counties in Kansas, the potential for negative effects on county streams is expected to intensify as municipalities within the county become more densely populated. The Kansas Department of Health and Environment (KDHE) has listed several Johnson County streams and lakes as impaired waterways (Kansas Department of Health and Environment, 2008) under section 303(d) of the 1972 Clean Water Act (CWA). Most stream impairments are related to excessive nutrients, bacteria, and sediment. Provisions of the CWA and the subsequent Water Quality Act (WQA) require that stormwater be controlled through the National Pollutant Discharge Elimination System (NPDES) permit program administered by the U.S. Environmental Protection Agency (USEPA). In addition, provisions of the CWA and WQA state that best management practices (BMPs) must be established to control nonpoint-source pollution. Routine monitoring of stream quality is necessary to better characterize stream conditions, to determine the most effective management strategies, and to document changes over time.

In 2002, the U.S. Geological Survey (USGS), in cooperation with the Johnson County Stormwater Management Program, began an investigation to characterize the water quality of Johnson County streams and to provide information for use by municipalities in the development of effective waterquality management plans. Initial study efforts described the effects of nonpoint and selected point contaminant sources on stream-water quality and their relations to land use (Lee and others, 2005), followed by a study to characterize biological conditions of county streams (Poulton and others, 2007). A subsequent phase of the study estimated water-quality constituent concentrations, loads, and yields for different watersheds (Rasmussen and others, 2008). Additional biological, habitat, water chemistry, and streambed-sediment chemistry data were collected in 2007 to provide an integrated assessment of overall stream quality.

Biological communities provide valuable information related to water quality and overall stream health. Benthic macroinvertebrate and algal periphyton data are two types of biological indicators that are useful for assessing stream health. Macroinvertebrate communities are important because their composition and community structure provide evidence of past physical and chemical conditions in a stream over a relatively long period of time. Periphyton consists of algae, bacteria, fungus, and other microorganisms that are attached to submerged substrates such as rocks and vegetation. Algal periphyton are primary producers and serve as an important food source for macroinvertebrates and some fish species. In part because of the sedentary nature of algal periphyton, these communities can be sensitive to changes in water quality and often are used as indicators of physical and chemical conditions.

Stream habitat assessments are used to relate habitat variables to other chemical, biological, and physical factors that describe water-quality conditions (Fitzpatrick and others, 1998). The information then can be used to determine important natural and anthropogenic (human-related) factors that affect stream conditions. Habitat assessments generally include information on streambank and channel features, riparian characteristics, and in-stream habitat conditions.

Biological and habitat data can be combined with water and streambed-sediment information to provide an integrated assessment of overall stream quality. Integrated assessments provide a more comprehensive examination of streams and aid in the identification of specific causes of stream impairments. Biological and water-quality data provide information related to the basic requirements for survival of aquatic biota and indicate whether applicable criteria or goals are being met. Sediment data provide information regarding fate, transport, and potential toxicity of chemicals that are associated with sediment such as metals and wastewater compounds and can be compared to sediment-quality guidelines. Sufficient data collection is needed to identify changes in conditions and to separate differences resulting from variability in climate and hydrology from those differences resulting from actual changes in stream-quality conditions.

Information developed during this study will be used to define 2003-07 stream-quality conditions in Johnson County, Kansas, and to identify changes compared to past results. The information will be used by the county and municipalities within the county to better understand specific factors affecting stream conditions, which potentially can lead to the development and implementation of more effective management plans. In addition, results from this study will be used to evaluate compliance with Federal and State water-quality standards, Total Maximum Daily Loads (TMDLs), NPDES permit conditions, and other established goals.

\section{Purpose and Scope}

The purpose of this report is to assess the quality of Johnson County streams by characterizing biological (algal periphyton and macroinvertebrate) communities and determining their relation to environmental variables such as water chemistry, streambed-sediment chemistry, land use, streamflow, and habitat conditions. Data collected in 2007 are compared to data collected during 2002-06 (Wilkison and others, 2006; Poulton and others, 2007) to document changing conditions. This report includes: (1) evaluation of water and streambed chemistry, (2) assessment of habitat conditions, (3) comparison of biological community attributes (such as composition, diversity, and abundance) among sampling sites, (4) placement of sampling sites into KDHE-defined impairment categories, (5) evaluation of biological data relative to environmental variables, and (6) evaluation of changes in biological communities including year-to-year variability and effects of urbanization on stream quality. 


\section{Acknowledgments}

The authors are grateful to Heather Schmidt and Lee Kellenberger of the Johnson County Stormwater Management Program for support and planning efforts associated with sampling activities. The authors also thank Tony Holt and other staff members of the Johnson County Environmental Laboratory for support in coordination of water-sample analysis. The authors appreciate the help of Shannon Porter with the Johnson County Automated Information Mapping System for providing land-use data. Finally, the authors also thank Scott Grotheer at the USGS National Water Quality Laboratory in Lakewood, Colorado, for technical assistance with macroinvertebrate taxonomy.

\section{Description of Study Area}

Most of the study area (fig. 1) is in Johnson County, Kansas, which is located in the western part of the Kansas City metropolitan area and consists of 477 square miles $\left(\mathrm{mi}^{2}\right)$ of surface area (U.S. Census Bureau, 2005). The county contains all or parts of 22 watersheds, the largest 11 of which are within the 20-site sampling network (fig. 1, table 1). Designated uses for streams within the county include support of aquatic life, contact recreation, drinking-water supply, food procurement, groundwater recharge, irrigation, industrial use, and livestock watering. In 2007, fourteen municipal wastewater-treatment facilities (WWTFs) were located in Johnson County watersheds, 10 of which had a capacity of more than one million gallons per day (Mgal/day) (fig. 1).

The mean annual temperature (1931-2006) in Olathe, Kansas, is about 57 degrees Fahrenheit $\left({ }^{\circ} \mathrm{F}\right)$, with a mean monthly range from $30^{\circ} \mathrm{F}$ in January to $79^{\circ} \mathrm{F}$ in July (National Oceanic and Atmospheric Administration, 2007). Mean annual precipitation (1931-2006) is about 38 inches (in.), with 69 percent of the precipitation occurring from April through September (National Oceanic and Atmospheric Administration, 2007).

Physiographic regions of Johnson County include the Osage Cuestas in the central and southern part and Dissected Till Plains in the northern part of the county (Schoewe, 1949). Underlying the county is sedimentary rock with alternating layers of limestone, shale, and fine-grained sandstone. Soils consist primarily of loess, glacial deposits, and residual from weathering of bedrock (Plinsky and others, 1975). Johnson County streams that flow north into the Kansas River (for example, Kill, Cedar, and Mill Creeks) generally have a steeper gradient than those flowing east (for example, Indian Creek and the Blue River) into the Missouri River (O'Connor, 1971).

Urban and suburban land use has increased substantially in Johnson County. Land parcels dedicated to residential and commercial land use increased more than 45 percent between 1990 and 2003 (Johnson County Appraiser's Office, written commun. 2004). The northeastern part of the county, including the Brush Creek, Dykes Branch, Indian Creek, Rock Creek, Tomahawk Creek, and Turkey Creek watersheds, contains the most urban development with more than 70 percent of the watersheds devoted to residential, commercial, industrial, and other urban land uses (Lee and others, 2005). More than 18 percent of these watersheds is covered by impervious surfaces compared to less than 3 percent in more rural parts of the county (Lee and others, 2005). The Blue River and Mill Creek watersheds have recently undergone the most rapid development (Mid-America Regional Council, 2002).

\section{Previous Investigations}

Macroinvertebrate communities in streams of Johnson County and selected downstream sites in Cass and Jackson Counties in Missouri were described by Poulton and others (2007) on the basis of data collected in 2003 and 2004. According to the report, biological conditions in Johnson County streams generally reflected a gradient in the degree of human disturbances upstream from the sites, including percentage of urban and agricultural land use as well as the presence, absence, and proximity of WWTF discharges. Upstream Blue River sites, with primarily agricultural land use, consistently scored among the sites least affected by human disturbance, and in some metrics these sites scored higher than the State reference site (Captain Creek; CA1). However, no sites, including the Captain Creek reference site, met KDHE criteria for full support of aquatic life during the 2 years of sample collection. Upstream sites on Kill and Cedar Creeks consistently scored among the least disturbed sites. Sites less than 3 miles (mi) downstream from municipal WWTF discharges (two Indian Creek sites IN3a and IN6) and sites with no wastewater discharge but with substantial impervious surface area within their respective watersheds (Brush, Tomahawk, and Turkey Creeks) consistently scored among the sites most affected by human disturbance.

Chemical concentrations, loads, and yields in five major Johnson County streams were described on the basis of continuous monitoring data and regression models (Rasmussen and others, 2008). Concentrations of suspended sediment, chloride, and fecal-indicator bacteria generally were larger in more urban watersheds than in nonurban watersheds and were substantially larger during periods of increased streamflow. At least 90 percent of the total suspended-sediment load in 2005-06 in all five watersheds occurred in less than 2 percent of the time, generally during the largest storm runoff. Chloride concentrations, which were strongly correlated with specific conductance, were consistently largest at the most urban sites and strongly affected by roadsalt runoff. More than 97 percent of the fecal coliform bacteria load at monitoring sites near wastewater discharges originated from nonpoint sources. Wastewater discharges were the primary source of nutrients in streams at sites downstream from those facilities.

Lee and others (2005) described the effects of contaminant sources on stream-water quality and their relation to 


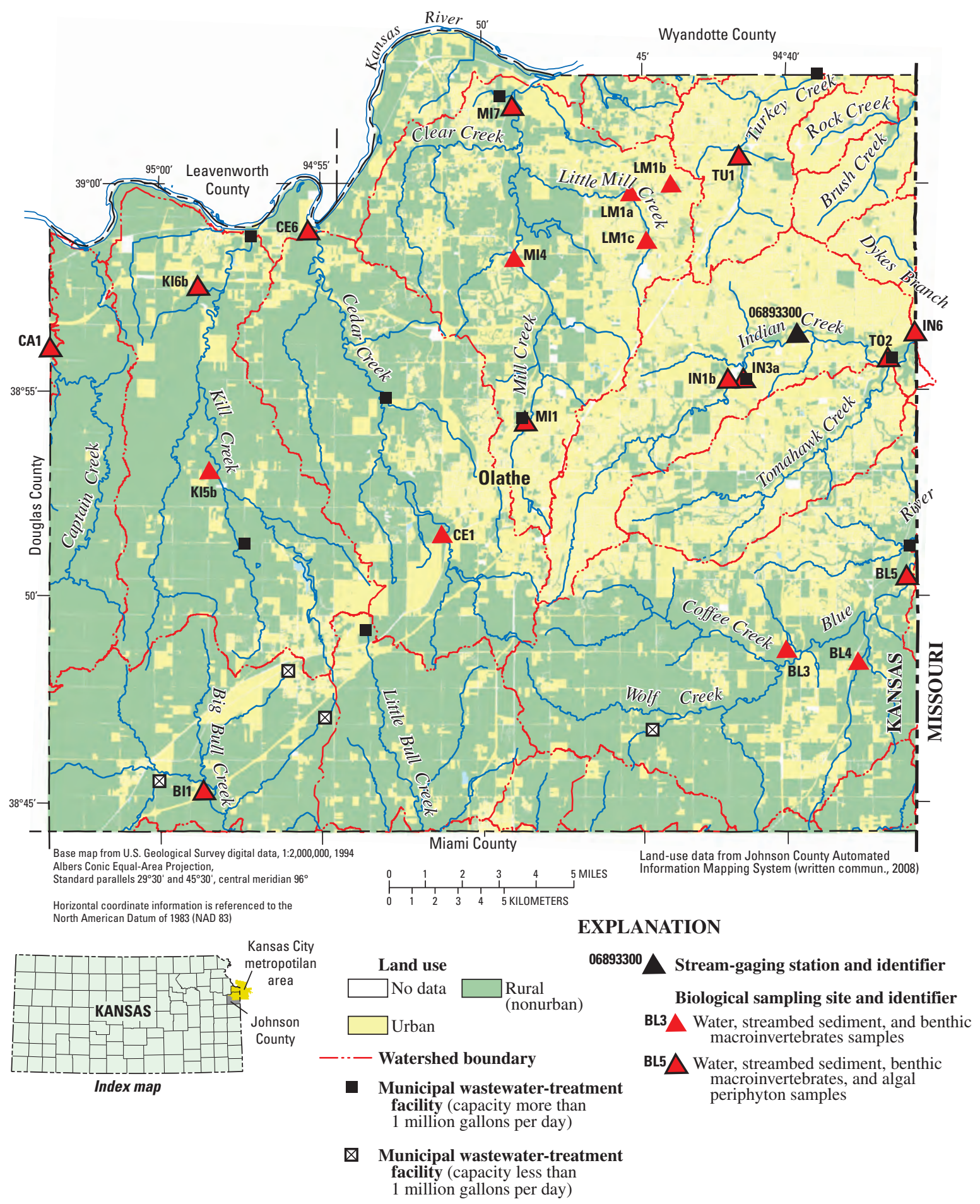

Figure 1. Location of biological sampling sites, selected municipal wastewater treatment facilities, and urban and rural land use in Johnson County, Kansas, 2007.

varying land use. According to the report, during base-flow conditions, discharge from WWTFs comprised more than 50 percent of streamflow at downstream locations in six of the seven watersheds. Nutrient, organic wastewater-indicator compound, and pharmaceutical compound concentrations generally were largest at sites immediately downstream from WWTFs during base flow. Stormflow samples had the largest suspended-sediment concentrations and fecal-indicator bacteria densities. Other than in samples from sites immediately downstream from wastewater treatment discharges, stormflow samples generally had the largest nutrient concentrations.

In addition to Lee and others (2005), USGS has examined components of urban stormwater runoff and point-source effluents within the Blue River and Indian Creek watersheds, 


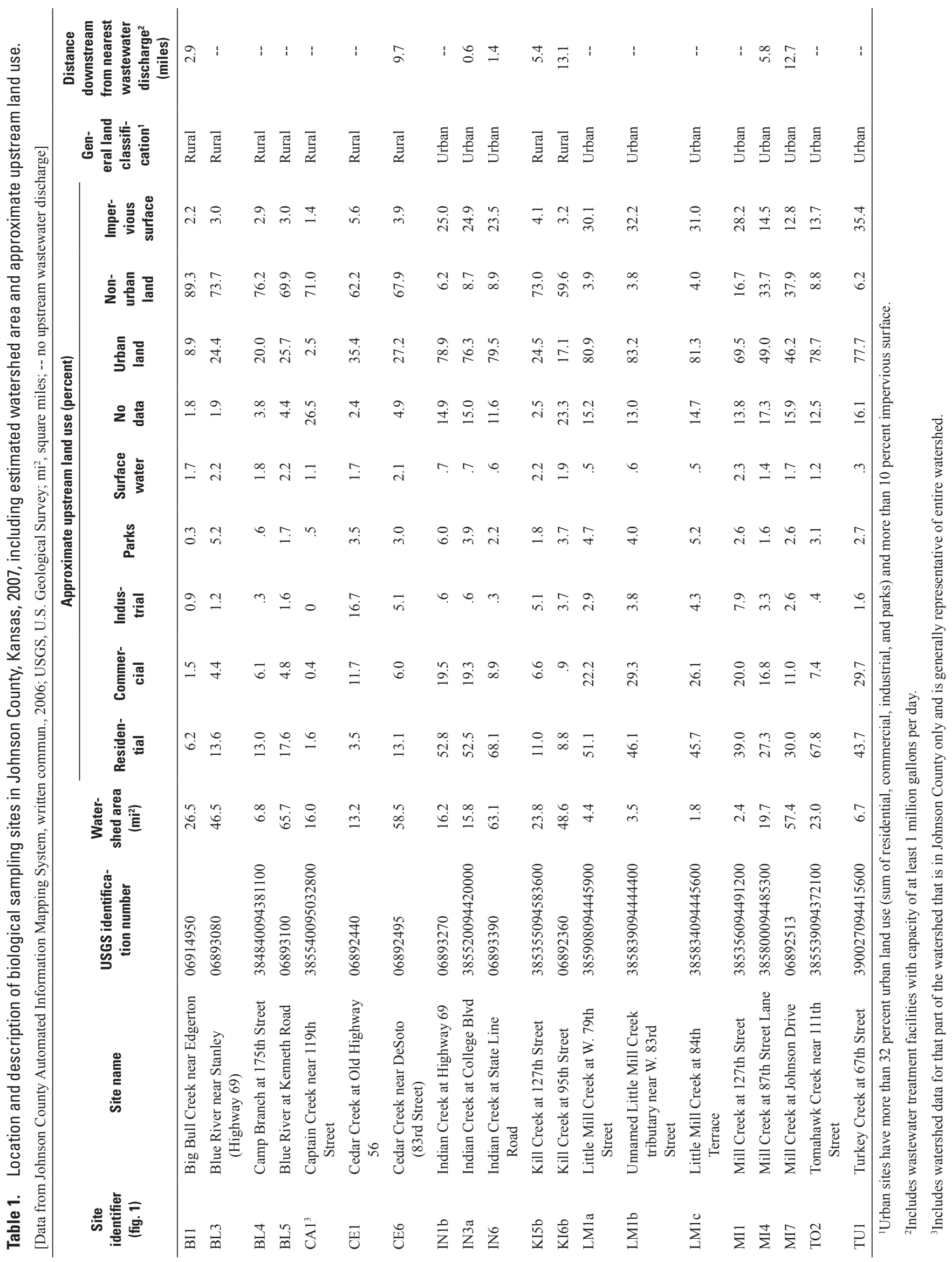


which are located in the southern part of the Kansas City metropolitan area in both Missouri and Kansas. In 2002, a macroinvertebrate bioassessment was added to these investigations (Wilkison and others, 2005, 2006). However, most of this work concentrated on hydrological modeling of nutrient loads, identification of tracer compounds and loads in streams and municipal effluents, water-quality monitoring, bacteriological source tracking, effluent discharge modeling, and determination of various contaminant loads in the receiving streams (Blevins, 1986; Wilkison and others, 2002, 2005, 2006).

\section{Methods}

\section{Study Design}

An overall assessment of stream quality was completed by integrating data for water and streambed-sediment chemistry, watershed variables (land use, streamflow, and precipitation), habitat, algal periphyton communities, and benthic macroinvertebrate communities. This information was evaluated and used to develop relations between variables and to determine possible causes of overall stream degradation.

Water, streambed-sediment, and benthic macroinvertebrate samples were collected in March 2007 at 20 sampling sites within the county (fig. 1) during base-flow conditions. Base flow is defined as the sustained low flow of a stream in the absence of direct runoff, usually originating from groundwater seepage, springs, and (or) wastewater discharges. In addition, habitat assessments were conducted at the same 20 sites during September 2007. Algal periphyton samples were collected twice (March and July) in 2007 at 11 of the 20 sampling sites. Periphyton were collected during two different seasons to evaluate seasonal differences. Spring (March) sampling was completed at the same time as water, streambed sediment, and macroinvertebrates and before the occurrence of streamflow increases normally associated with spring storm runoff. Summer periphyton samples were collected after approximately 2 weeks with no major inflow. The 20 sampling sites were distributed among the major watersheds in Johnson County including Indian, Turkey, Mill, Cedar, Kill, Captain, and Big Bull Creeks and the Blue River. Sampling sites included stream sites where samples were collected in 2003 and 2004 as part of previous studies (Lee and others, 2005; Poulton and others, 2007; Rasmussen and others, 2008). Also included were five new sites, three of which were headwater streams in the Mill Creek watershed (LM1a-c). Captain Creek, a State reference stream located in the western part of the county, also was sampled. Reference streams are streams designated by the State as being minimally disturbed by human activity. The sampling sites were representative of various land-use types, extent of urbanization, and sources of streamflow including wastewater treatment discharges. The sampling data were combined with land-use data for analysis.
In this report data from 2007 are compared to data from 2002-04 (Lee and others, 2005; Poulton and others, 2007). A total of 16 sites in Johnson County and 6 sites in adjacent counties in Missouri were sampled for macroinvertebrates during 2003 and 2004. The same 16 Johnson County sites, with one exception, plus 4 additional sites were sampled in 2007. The one exception was an upstream site on Kill Creek (site KI5, Poulton and others, 2007) that was sampled about 1.5 mi downstream at site KI5b for the 2007 sampling because of changes in stream access. There are no known inputs from point sources or major tributaries between these two sampling sites. Therefore, data for the two sites were combined and considered to be the same site.

Also in this report, statistical relations are evaluated between biological data and water and streambed-sediment data. Water and sediment samples collected at about the same time biological samples were collected are used to develop relations. However, one water sample and one streambedsediment sample may not be adequate to accurately characterize base-flow conditions. In addition, biological communities likely are affected by water chemistry during high flow as well as low flow. High-flow water chemistry was not evaluated in the analysis. Therefore, some important relations may not have been identified.

\section{Data Collection}

\section{Stream-Water and Streambed-Sediment Sampling}

Stream-water and streambed-sediment samples were collected during base-flow conditions March 12-15, 2007, the same days that macroinvertebrate and periphyton samples were collected (fig. $2 A-D$ ). Water samples were collected following equal-width-increment (EWI) methods described by the U.S. Geological Survey (2006). Streambed-sediment samples were collected from the upper 0.8 in. of deposition using stainless-steel spoons. Only the most recently deposited fine material was removed from several depositional zones along the streambed and placed in glass or plastic containers, homogenized, and shipped for analysis (Pope, 2005; Radtke, 2005).

\section{Watershed Variables_-Land Use, Streamflow, Precipitation}

Estimates of land-use percentages were determined for all of the sampling sites. Land-use data were obtained from the Johnson County Automated Information Mapping System (AIMS) (Johnson County, written commun., 2006). Impervious surface data were estimated by adding the total area of all buildings, courtyards, and paved and unpaved roads and parking lots. Percentage of urban land use was generated by 

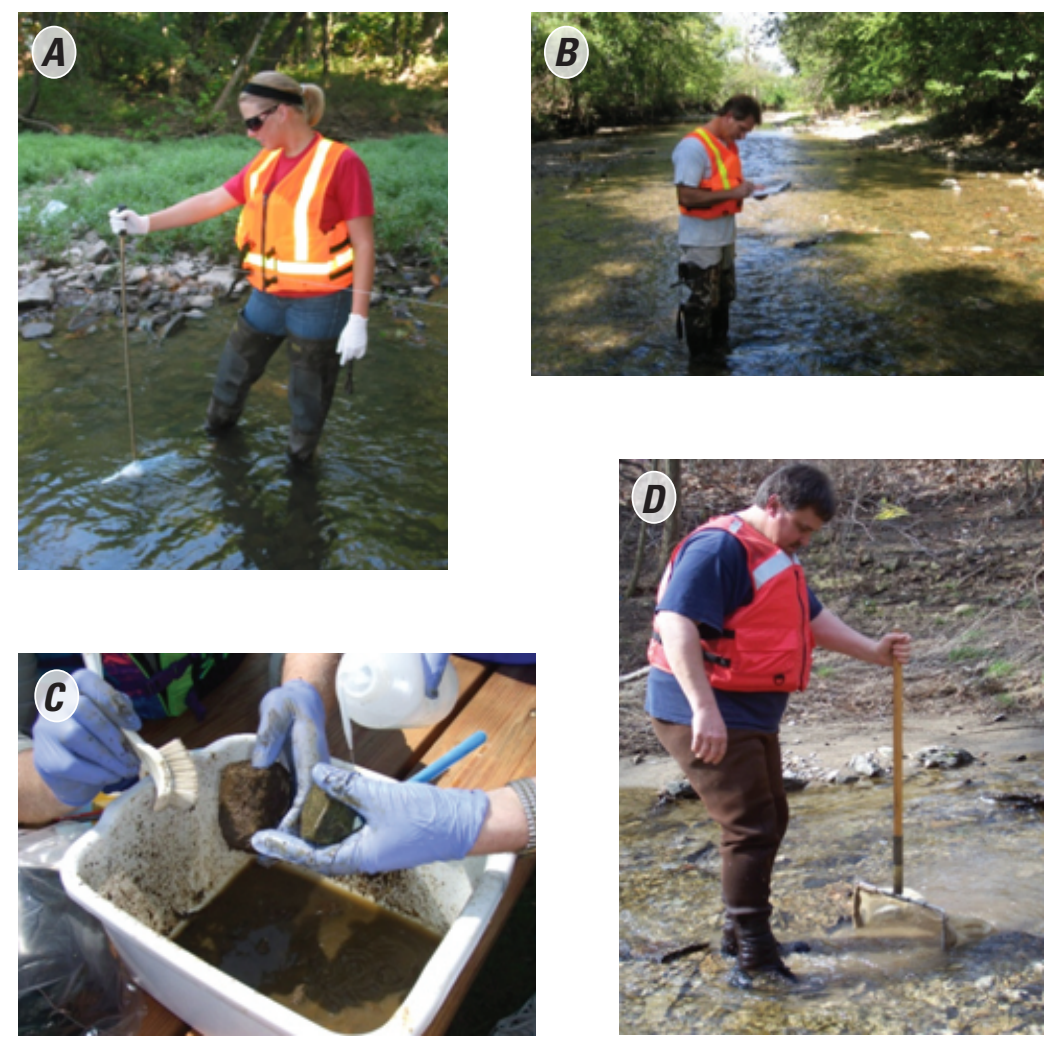

Figure 2. Data collection activities at biological sampling sites in Johnson County, Kansas, 2007, including (A) collecting a water sample for chemical analysis, $(B)$ conducting a habitat assessment, $(C)$ scraping periphyton from streambed rocks, and (D) using a kicknet to collect macroinvertebrates.

combining the percentages of parks, residential, commercial, and industrial land use.

Aquatic ecosystems are strongly affected by streamflow characteristics. The physical structure of ecosystems is a function of the interaction between streamflow and the landscape (Leopold and others, 1992). The structure and function of biological communities depend on the streamflow regime, which includes magnitude, timing, duration, and frequency of high and low flows (Poff and Ward, 1989). Streamflow characteristics have been found to strongly affect physical stream features, habitat, productivity, and ultimately the composition of benthic periphyton and macroinvertebrate communities (Konrad and others, 2008). In addition, streamflow often is linked to other environmental factors that affect biological communities such as water temperature, dissolved oxygen, particulate matter, and dissolved substances.

USGS stream gages were in operation at 7 of the 20 biological sampling sites. Streamflow data for these gages were examined during the 2 months prior to sampling to help interpret macroinvertebrate and periphyton results. In addition, precipitation data from the stream-gaging stations were used to assess precipitation patterns prior to sampling and to compare climatic conditions between sites.

Statistical streamflow metrics were calculated and used as variables in correlation analysis to better understand factors that affect biological conditions. Selected streamflow variables used in analysis were obtained from the USGS Streamstats Web site (Perry and others, 2004, data available at http://ks.water. usgs.gov/studies/strmstats/), calculations for data through 2007 (U.S. Geological Survey, written commun., 2008) using techniques described by Stewart and others (2006), and the Nature Conservancy's Indicators of Hydrologic Alteration (IHA) method (Richter and others, 1996). Available periods of record for streamflow gages varied from 3 to 34 years. Although more than 100 different streamflow metrics were calculated using different methods and periods of record, about 18 metrics were selected that affected stream ecosystems in different ways, differentiated among sites, and represented minimal redundancy. The streamflow metrics used in the final analyses were calculated using only data from 2005-07 to have periods of record that were consistent among sites. A summary of streamflow metrics used in these analyses is provided in table 2 .

\section{Habitat Assessment}

Habitat assessment is the evaluation of the surrounding physical habitat characteristics that contribute to the quality of a water resource and the condition of the aquatic community (Barbour and others, 1996). Habitat-quality assessments are an attempt to integrate several of the factors that directly or indirectly affect the biological and water-quality condition of streams and rivers. Evaluation of stream habitat quality, which generally includes an evaluation of the variety and quality of the substrate, channel morphology, bank structure, and riparian vegetation, is a critical part of assessing ecological integrity and is related to the composition (diversity and abundance) of aquatic communities (Barbour and others, 1999). A decline in the quality and diversity of in-stream habitat generally is considered one of the major stressors in aquatic systems (Karr and others, 1986). Numerous habitat evaluation protocols have been published within the last 25 years (Ball, 1982; Platts and others, 1983; Plafkin and others, 1989; Terrell and Perfetti, 1989; Barbour and Stribling, 1991, 1994; Galli, 1996; Fitzpatrick and others, 1998; Natural Resources Conservation Service, 1998; Barbour and others, 1999; Kaufman and others, 1999 to name a few). Other unpublished habitat protocols have been developed by State water-pollution agencies, which represent a collection of individual measurements that have been selected from published protocols, for the purpose of developing a habitat evaluation framework tailored to the specific types of streams found within those State boundaries. State protocols are used most commonly in conjunction with biological sampling to determine the impairment status of 
Table 2. Summary of streamflow metrics used in analyses of biological and water-quality data for streams in Johnson County, Kansas, 2007.

\begin{tabular}{|c|c|c|}
\hline General characteristic & Streamflow metric & $\begin{array}{c}\text { Examples of ecosystem effects (Richter and } \\
\text { others, 1996) }\end{array}$ \\
\hline $\begin{array}{l}\text { Magnitude of monthly streamflow } \\
\text { conditions ( } 2 \text { months prior to } \\
\text { sampling) }\end{array}$ & $\begin{array}{l}\text { Median monthly streamflow, January } \\
\text { Median monthly streamflow, February }\end{array}$ & $\begin{array}{l}\text { Habitat availability, soil moisture availability, } \\
\text { water temperature, dissolved oxygen }\end{array}$ \\
\hline $\begin{array}{l}\text { Magnitude and duration of annual } \\
\text { streamflow conditions }\end{array}$ & $\begin{array}{l}\text { Mean annual streamflow } \\
\text { Base-flow index } \\
\text { Minimum 7-day mean streamflow } \\
\text { Percentiles of daily flow } \\
\text { Minimum daily flow } \\
\text { Maximum daily flow } \\
\text { Standard deviation of daily flow }\end{array}$ & $\begin{array}{l}\text { Shape and form new habitats, create colonizing } \\
\text { sites, flush organic materials into channel, } \\
\text { purge invasive species, disperse seeds, dura- } \\
\text { tion of stressful conditions }\end{array}$ \\
\hline $\begin{array}{l}\text { Frequency and duration of low/high } \\
\text { streamflow pulses }\end{array}$ & $\begin{array}{l}\text { Low pulse count } \\
\text { High pulse count } \\
\text { Low pulse threshold } \\
\text { High pulse threshold }\end{array}$ & $\begin{array}{l}\text { Shape river channel, pools, and riffles, deter- } \\
\text { mine size of streambed substrate, prevent } \\
\text { riparian vegetation from encroaching into } \\
\text { channel, flush away waste, exchange nutri- } \\
\text { ents }\end{array}$ \\
\hline $\begin{array}{l}\text { Magnitude and rate of change in } \\
\text { streamflow conditions }\end{array}$ & $\begin{array}{l}\text { Rise rate } \\
\text { Fall rate } \\
\text { Standard deviation (std dev) of the daily flow } \\
\text { Coefficient of variability (std dev/mean) } \\
\text { Ratio of } 75 \text { th to } 25 \text { th percentile } \\
\text { 90th minus } 10 \text { th percentile/50th percentile }\end{array}$ & $\begin{array}{l}\text { Drought stress on plants (falling streamflow), } \\
\text { entrapment, tolerance under variable condi- } \\
\text { tions }\end{array}$ \\
\hline
\end{tabular}

water bodies and ultimately have a great deal of overlap with many of the published habitat protocols previously cited.

General habitat conditions that are optimum for supporting healthy macroinvertebrate and fish communities are reasonably well defined for wadeable stream systems in most ecoregions of the United States (Barbour and others, 1999). However, some measurements may not provide definitive results for particular stream types (such as urban streams) or sources of impairment (such as altered hydrology). In general, literature suggests that application of some habitat assessment protocols may not be appropriate for stream systems in urban areas (Roy and others, 2005; Walsh and others, 2005a, 2005b) and that there is a need for developing specific urban stream protocols that incorporate the most ecologically relevant factors. Symptoms of habitat degradation in urban watersheds may be different when compared to rural streams or in some cases may be more or less pronounced. In part, this is because most habitat assessments focus on stream-reach features when the causative factors for stream impairment in urban areas often need to be measured at the segment or watershed scale because they may not occur within the stream reach. These variables include features such as mean riparian buffer length and width, number of stormwater outfalls entering upstream from the site, amount of impervious surface, and degree of connectivity in impervious surfaces, all of which have been identified as important large-scale metrics that affect hydrology and subsequent in-stream habitat quality (Walsh and others, 2005b). The Rapid Habitat Assessment used by KDHE (Kansas Department of Health and Environment, 2007) considers 10 habitat characteristics all of which are reach-scale features. The Habitat Development Index (HDI), also used by KDHE, considers 7 reach-scale habitat features (Huggins and Moffett, 1988).

The protocol used in this study consisted of a collection of 17 variables selected from previously published protocols for the purpose of developing a habitat evaluation framework tailored to the specific types of streams found within the study area, including both urban and rural streams. The USEPA's Rapid Habitat Assessment Protocol (Barbour and others, 1999) was the foundation for most of the variables used. The USEPA protocol includes habitat characteristics similar to the 10 used in the KDHE protocols plus several others thought to be important such as length and extent of stream buffers. Some of the variables were modified in the protocol used for this study to provide more meaningful information about both urban and rural streams in this particular geographic region and to better differentiate among sites. For example, stream buffers were characterized on a larger scale and using information on interruptions in buffer, in addition to average width. Data collection was completed using a combination of onsite measurements and observations that were made in September 2007 (fig. 2B), and available aerial photography and topographical maps. All habitat data-collection sites were located at existing water-quality and biological sampling sites that were selected to represent multiple watersheds and the range of streamquality conditions in the study area. The complete protocol is provided in Appendix 1. 
In addition to having specific measurements, each variable was assigned a score on a scale of 1 to 12 , with four rating categories of relative quality (a score of 1 to 3 is poor; 4 to 6 is marginal; 7 to 9 is suboptimal; and 10 to 12 is optimal). Each category of variables was scored separately and also integrated into one total site score by summing each of the individual scores. Both individual and total habitat scores were used in data analysis to describe habitat conditions and relations with other biological and chemical variables.

\section{Periphyton Sampling}

Periphyton samples were collected from 11 sites in Johnson County (fig. 1) during spring (March 12-15, 2007) and summer (July 23-26, 2007). Nine of the 11 sampling sites were selected to coincide with the furthest downstream site in each watershed. The remaining 2 sites were located upstream and downstream from the WWTF discharge into Indian Creek.

A single-habitat sampling approach was used to collect periphyton samples in Johnson County streams (Moulton and others, 2002). Streambeds in Johnson County are dominated by coarse-grained substrates (gravel and cobbles); therefore, cobble substrate in riffles and runs were sampled for periphyton at each monitoring site. These riffle-run locations coincided with the same riffles that were included in the macroinvertebrate sampling. The single habitat sampling approach is recommended (Moulton and others, 2002) for the assessment of periphyton biomass. In addition, sampling the same habitat at each site helps to minimize variability among sites because of differences in habitat (Stevenson and others, 1999; Moulton and others, 2002).

Periphyton samples were collected from a composite of cobbles collected from three adjacent riffles at each site. Three cobbles were collected randomly from each of the three riffles (a total of nine cobbles per site), placed in a plastic dishpan, and transported to an onsite processing station. Using a small brush, periphyton samples were scraped from each cobble and rinsed into the dishpan using filtered stream water (fig. 2C). This process was repeated several times until all of the visible periphyton were removed from each cobble. After all cobbles were scraped, periphyton material was rinsed from the dishpan into a graduated cylinder. Sample volume was recorded and the sample was poured into a 1-liter (L) high-density polyethylene (HDPE) amber bottle (Stevenson and Bahls, 1999; Moulton and others, 2002; Hambrook-Berkman and Canova, 2007). After vigorous shaking, duplicate samples were collected for chlorophyll analysis. Chlorophyll samples were processed as described in Hambrook-Berkman and Canova (2007). The sample remaining after chlorophyll processing was preserved with a 9:1 Lugol's iodine: acetic acid solution for taxonomic and biovolume analysis. To determine the surface area of each cobble from which periphyton was scraped, aluminum foil was molded to the scraped area of each cobble and excess foil was trimmed. The area of each foil template was determined by using a digitizing table as a planimeter. Areas for all cobbles in a sample were summed to determine the total surface area sampled (Hambrook-Berkman and Canova, 2007).

\section{Macroinvertebrate Sampling}

Macroinvertebrate community samples were collected from multiple habitats at the 20 sites during base-flow conditions on March 12-16, 2007 (fig. 2D). No periods of runoff occurred during the 10-day period prior to sample collection. The most recent rainfall may have totaled about 2 in. over several days at some locations but was not thought to substantially affect benthic communities. Sampling was conducted in March to obtain samples representative of benthic communities and to precede pulses of early spring runoff that may have disrupted benthic populations. In addition, macroinvertebrate samples collected from small streams in late winter and early spring seasons often have greater diversity compared to samples collected in other seasons (Feminella, 1996) because emergence periods of many stream insect species coincide with spring and early summer periods.

The KDHE macroinvertebrate protocol (Kansas Department of Health and Environment, 2000), which is a semiquantitative method using timed sampling from multiple habitat types, was followed for sample collection. Minor adjustments were made to the KDHE protocol to improve consistency between sample collections. Two independent 100-organism samples were collected and counted onsite by two scientists. Each site was sampled simultaneously for about 1 hour. If 100 organisms were not obtained in the allotted time period, sampling ended. Macroinvertebrate samples were collected with standard 9 in. x 18 in. rectangular frame kicknets with mesh size approximately 500 micrometers $(\mu \mathrm{m})$ following physical disturbance of the substrate upstream from the net (fig. 2D). In standing-water habitats, the net was used with a sweeping or scooping motion. A large white sorting tray (31 in. x 25 in. x 2.75 in.) elevated on a portable stand at streamside was used to spread out debris during sorting. A small amount of water was placed in the sorting tray along with the sample debris to enhance the visibility of the organisms. A hand counter was used to count the organisms as they were removed from the tray with forceps. Removal of organisms followed the morphospecies principle, meaning that any organism visually appearing different from those previously sorted was included in the sample. Organism size was considered, making certain that both large and small animals were included.

A maximum diversity of organisms was obtained during sorting, and each sample represented relatively uniform coverage of the habitats present. When possible, not more than 25 percent of the organisms sorted came from any one of the habitats available. To minimize bias in the sample collection process, a checklist of the major stream habitats was completed at each site to assure thorough sample coverage. The habitats generally were located in both fast-flowing areas and slack water. These habitats included coarse gravel and cobble in riffles, fine gravel and sand/silt substrates near the margins or in runs, leaf packs or organic matter accumulations, 
vegetation and undercut banks along margins or around snags, and large moveable objects such as logs or rocks where handpicking may reveal additional taxa.

All of the 100-organism samples were preserved in 80-percent ethanol onsite in 125-milliliter $(\mathrm{mL})$ polyethylene bottles. The sample bottles were labeled with site name, date, and collector's initials. Samples were topped off with preservative and sealed with tape before being sent to the USGS National Water Quality Laboratory (NWQL) in Lakewood, Colorado, for identification and enumeration. In this study, the two independent samples were combined into one 200-organism sample after laboratory enumeration and identification were completed.

To enhance statistical comparisons among sites, replicate samples were collected at one urban site and one rural site. At these sites, the same sampling protocol was applied three successive times at separate riffle-pool sequences within the particular reach.

\section{Sample Analysis}

Water samples were analyzed for suspended sediment, dissolved solids, major ions, nutrients (nitrogen and phosphorus), trace elements, fecal-indicator bacteria, and pesticide compounds. Suspended-sediment concentration was analyzed at the USGS Sediment Laboratory in Iowa City, Iowa, according to methods described in Guy (1969). Major ions, nutrients, and fecal-indicator bacteria were analyzed at the Johnson County Environmental Laboratory in Johnson County, Kansas according to standard methods (American Public Health Association and others, 1995), and selected replicate samples were sent to the NWQL in Lakewood, Colorado, and analyzed according to methods presented in Fishman and Friedman (1989). Pesticides were analyzed at the NWQL using methods described by Zaugg and others (1995).

Streambed-sediment samples were analyzed for total organic carbon, total carbon, major ions, nutrients, trace elements, pesticides, and organic wastewater compounds. Organic wastewater compounds generally include chemicals used in and around the home (such as detergents, plasticizers, and fragrances), which typically are associated with wastewater effluent but can occur throughout watersheds particularly in urban areas. Sediment chemical analysis was performed at the Atlanta, Georgia, USGS sediment chemistry laboratory using digestion after homogenization and passage through a $63-\mu \mathrm{m}$ sieve (Horowitz and others, 2001). Pesticides and wastewater compounds in streambed sediment were analyzed according to methods described by Foreman and others (1995) and Burkhardt and others (2006).

Total chlorophyll was extracted in heated ethanol and analyzed fluorometrically (Knowlton, 1984; Sartory and Grobbelar, 1986). Periphyton samples were analyzed for taxonomic identification, enumeration, and biovolume of soft algae and diatoms by BSA Environmental Services, Inc. (Beachwood, Ohio). The soft algae in the periphyton samples were first enumerated to the lowest possible taxonomic level using membrane-filtered slides (McNabb, 1960). A minimum of 400 natural units were counted. Diatoms were counted by natural unit as a general category, and then examined more closely in permanent diatom mounts. Diatom slides were made using the traditional nitric acid digestion method (Patrick Center for Environmental Research, 1988). A minimum of 400 valves were identified to the lowest possible taxonomic level. Biovolume factors for both soft algae and diatoms were calculated using the methods described in Hillebrand and others (1999). Diatom biovolumes were calculated from the permanent slides. A mean biovolume measurement per cell was calculated for each sample, and that value was used as the biovolume measurement in the general diatom category.

Identification and enumeration of the macroinvertebrates were completed by the USGS NWQL in Lakewood, Colorado. The taxonomic references used for each of the organism groups are outlined in Moulton and others (2000) and represent the same procedure used by the USGS National Water-Quality Assessment (NAWQA) Program for obtaining biological data from stream samples. This included examination of most specimens under a dissecting microscope and mounting of midge specimens (Diptera: Chironomidae) on glass slides for identification under a compound microscope. In general, identification was to the lowest practical taxonomic level (usually genus or species).

\section{Data Analysis}

\section{Periphyton Data}

The diatom metrics percentage of eutraphentic (high nutrient) diatoms (Bacillariophyta) (sum of Amphora, Cocconeis, Diatoma, Gyrosigma, Meridion, Nitzchia, and Synedra biovolume), percentage of Navicula, percentage of Nitzschia, percentage of low nutrient diatoms (sum of Achnanthes, Cymbella, and Encyonema biovolume), and percentage of motile diatoms (sum of Gyrosigma, Navicula, Nitzchia, and Sururella biovolume) were calculated to indicate contributions to total periphyton biovolume (Stevenson and Rollins, 2007). Additional periphyton community metrics, including division richness, taxa richness, relative abundance of diatoms, relative abundance of the dominant diatom taxa, relative abundance of nitrogen-heterotrophic diatoms, siltation index, Shannon diversity, and Bahls pollution tolerance were calculated using the Algal Data Analysis Software (ADAS) developed for NAWQA (Cuffney, 2003). During analysis with ADAS, unknown or rare taxa were not deleted, and lowest taxanomic levels were used. Biovolume, rather than total taxa or cell counts, were used to calculate all periphyton metrics because biovolume is indicative of algal biomass (Lowe and Pan, 1996). The metrics used in the analysis were selected because they are recommended by Stevenson and Rollins (2007), used in USEPA's Rapid Bioassessment Protocol (Barbour and 
others, 1999), and commonly show patterns in the data. Nonparametric Wilcoxon signed-rank analysis (Sokal and Rohlf, 1995) was used to test statistical differences between datasets. The analysis tests whether median differences between ranks of paired data values is 0 (the null hypothesis) and the z-value represents the test statistic. The probability value ( $p$-value) represents the probability that the null hypothesis is incorrect. Smaller p-values offer stronger evidence that the paired data values are significantly different.

\section{Macroinvertebrate Data}

A total of 11 metrics were used to evaluate the macroinvertebrate data (table 3). They include the four KDHE aquatic-life metrics (Kansas Department of Health and Environment, 2008), plus those used in Poulton and others (2007) for multimetric site scoring. Using the same metrics that were used in Poulton and others (2007) made it possible to make comparisons between previous results and the 2007 data for 16 of the 20 sampling sites. These metrics represent core metrics used in many State evaluation programs, and those known to be sensitive and reliable for measuring degradation of stream assemblages on the basis of available literature. Nine of the 11 metrics determined in this study were generated by the Invertebrate Data Analysis System (IDAS) developed for NAWQA (Cuffney, 2003). Choices made using IDAS during data processing included selection of lowest taxonomic levels, no deletions of rare or unknown species, and resolving taxonomic ambiguities by retaining ambiguous data. Because this automated program does not include calculations for two of the KDHE aquatic-life assessment metrics, both the Macroinvertebrate Biotic Index (MBI; Davenport and Kelly, 1983) and the Kansas Biotic Index (KBI-NO; Huggins and Moffet, 1988) were calculated as described in these references.

Even though the IDAS program was not used to determine metric values from 2003 and 2004 as described in Poulton and others (2007), the metric equations and data processing steps used for these metrics were the same across years for all but one metric. The Shannon Diversity Index was calculated using $\log _{10}$ in the IDAS program, and these values were converted to natural logarithms so that data for this metric could be compared directly to biological data from Poulton and others (2007). $\log _{10}$ values were converted to natural log values by multiplying by 0.4343 (Brower and others, 1990).

Macroinvertebrate communities at the sampling sites were evaluated using multimetric site scores to compare relative conditions or degree of biological disturbance. The multimetric scores integrated 10 metrics (table 3) that measure various community aspects, including diversity, composition, tolerance, and feeding characteristics, and were calculated using the same methods described in Poulton and others (2007). In this study, the 10-metric combination was used to represent a measure of stream condition on the basis of macroinvertebrate communities and to provide a continuum

Table 3. List of macroinvertebrate metrics, abbreviations, and references used for assessment of biological conditions at biological sampling sites in Johnson County, Kansas, 2007.

[KDHE metrics are those used for evaluating the condition of aquatic life in Kansas streams (Kansas Department of Health and Environment, 2008). $<$, less than]

\begin{tabular}{|c|c|c|c|}
\hline Metric name and reference (if available) & Abbreviation & KDHE metrics & Used in multimetric score \\
\hline $\begin{array}{l}\text { Macroinvertebrate Biotic Index (Davenport } \\
\text { and Kelly, 1983) }\end{array}$ & MBI & $\mathrm{X}$ & $\mathrm{X}$ \\
\hline $\begin{array}{l}\text { Kansas Biotic Index, KBI-NO (Huggins and } \\
\text { Moffett, 1988) }\end{array}$ & KBI & $\mathrm{X}$ & $\mathrm{X}$ \\
\hline $\begin{array}{l}\text { Ephemeroptera-Plecoptera-Trichoptera } \\
\text { (EPT) taxa richness (Klemm and others, } \\
\text { 1990) }\end{array}$ & EPTRich & $\mathrm{X}$ & $\mathrm{X}$ \\
\hline $\begin{array}{l}\text { Percentage of EPT (Barbour and others, } \\
\text { 1999) }\end{array}$ & $\%$ ЕРT & $\mathrm{X}$ & \\
\hline $\begin{array}{l}\text { Total taxa richness (Barbour and others, } \\
\text { 1999) }\end{array}$ & TRich & & $\mathrm{X}$ \\
\hline $\begin{array}{l}\text { Percentage of scrapers (Barbour and others, } \\
\text { 1999) }\end{array}$ & $\% \mathrm{Sc}$ & & $\mathrm{X}$ \\
\hline $\begin{array}{l}\text { Percentage of }(\%) \text { Oligochaeta (Lenat, 1993; } \\
\text { Kerans and Karr, 1994) }\end{array}$ & $\%$ Olig & & $\mathrm{X}$ \\
\hline $\begin{array}{l}\text { Percentage of Tanytarsini midges (DeShon, } \\
\text { 1995) }\end{array}$ & \%Tany & & $\mathrm{X}$ \\
\hline $\begin{array}{l}\text { Percentage of intolerant organisms (KBI < } \\
\text { 3), (Huggins and Moffett, 1988) }\end{array}$ & $\%$ Int-KBI & & $\mathrm{X}$ \\
\hline Percentage of Ephemeroptera and Plecoptera & $\% \mathrm{EP}$ & & $\mathrm{X}$ \\
\hline Shannon Diversity Index (Washington, 1984) & SDI & & $\mathrm{X}$ \\
\hline
\end{tabular}


of biological response to overall human-induced disturbances among the study sites as outlined by the Biological Condition Gradient conceptual model (Davies and Jackson, 2006). Integrating individual metrics into multimetric combinations minimizes the bias that might occur when relying on only one or two metrics for evaluation (Karr and Kerans, 1991: Karr, 1993; Fore and others, 1994; Barbour and others, 1995).

To determine the relative biological quality of the sites, values for each of the 10 metrics used in the multimetric scoring were proportionally scaled among all of the sites for each metric. This approach transformed the metric values to numbers between 1 and 100, assigning 1 to the value representing the poorest biological quality and 100 to the value representing the optimum biological quality (Kreis, 1988). This method has three important features: (1) it spreads out the distribution of metric values, and when multimetric scores are obtained, there is less chance of having ties during the site-ranking process; (2) it retains the relative (or proportional) distances among the metric values; and (3) individual metrics have equal weight in the assessment results because each metric is transformed to the same numerical scale. This method has been used successfully for ranking sites on the basis of benthic macroinvertebrate data (Poulton and others, 1995; Poulton and others, 2007). Multimetric scores for sites were determined by summing proportionally transformed values for each of the 10 metrics. A ranking of sites was obtained on the basis of the sum of these scores. The scaling equations for individual metrics follow:

If the maximum value (Max) represents the optimum biological quality, use:

$$
1+[(\text { Value }- \text { Min }) /(\text { Max }- \text { Min }) \text { x 99]; }
$$

If the minimum value (Min) represents the optimum biological quality, use:

$$
1+[\{1-(\text { Value - Min) / (Max - Min })\} \text { x 99]; }
$$

Where

$$
\text { Value }=\text { number to be scaled. }
$$

Thus, values for the 10 metrics range from the lowest (1) to the highest (100) with a minimum possible multimetric score of 10 and a maximum possible score of 1,000.

The State of Kansas uses four macroinvertebrate metrics (table 3) for determining the ability of a stream site to support aquatic life and for placement of sites into impairment categories (Kansas Department of Health and Environment, 2008). A fifth metric, mussel community loss, also is used only if the site is known to support at least five mussel species. The percentage of mussel community loss was not evaluated in this study because several watersheds were considered too small in size to contain at least five mussel species.

To determine the aquatic-life status and relative degree of impairment for the sampling sites, scores were determined using the four aquatic-life status metrics used by the State of Kansas. The State metrics include MBI, KBI-NO, Ephemeroptera-Plecoptera-Trichoptera taxa richness (EPTRich), and Ephemeroptera-Plecoptera-Trichoptera abundance (\%EPT). Each metric was scored on a three-point system that was based on State criteria (Kansas Department of Health and Environment, 2008). Impairment status for each site was determined by combining these metric scores into an overall site score representing the mean across all of the metrics included.

For each of the two sites where replicate macroinvertebrate samples were collected, each of the 11 metrics was calculated by averaging values from the three replicate samples; multimetric scores were determined using the replication average.

\section{Relating Biological Data to Environmental Variables}

Nonparametric statistical analyses were conducted to determine relations between macroinvertebrate and periphyton communities, water and streambed-sediment quality, habitat measurements, and watershed variables including land-use and streamflow variables. SAS (ver. 8) software (Delwiche and Slaughter, 1998) was used to determine Spearman rank correlations for evaluating associations between data. Spearman rank correlation coefficients (rho values) were considered significant when probability values ( $\mathrm{p}$-values) were less than 0.05 and highly significant when $p$-values were less than 0.001. The nonparametric PRIMER (ver. 6) software (Clarke and Ainsworth, 1993; Clarke and Warwick, 2005; Clarke and Gorley, 2006) was used to evaluate variable similarities and for principal component analysis (PCA) and nonmetric multidimensional scaling (MDS). The PRIMER software employs nonparametric and permutation approaches to reduce the ecological complexities of multivariate data (many species and many environmental variables) and graphically displays relations between biological communities, sampling sites, and environmental variables (Clarke and Warwick, 2005). Correlations and multivariate analyses are used to characterize relations between stream variables and processes but do not establish direct causes and effects.

\section{Quality Assurance and Quality Control}

\section{Water and Streambed-Sediment Data}

Quality-assurance and quality-control samples were collected during both stream-water and streambed-sediment sampling. Relative percentage difference (RPD) was used to evaluate differences in analyte concentrations detected in replicate water samples. RPD is calculated as [|A-B $\mid /$ $(\mathrm{A}+\mathrm{B}) / 2)] \mathrm{x} 100$, where $\mathrm{A}$ and $\mathrm{B}$ are concentrations in each replicate pair. Generally, the median RPD between replicate water sample pairs was less than 10 percent except for some 
nutrients and pesticides with median RPDs as large as 20 percent and fecal-indicator bacteria with median RPDs as large as 30 percent. Replicate pairs of nutrients and trace elements in streambed-sediment samples indicated RPDs less than 10 percent with the exception of nitrogen, which was about 20 percent. Complete results from all sample analyses including replicate and blank samples are available on the USGS Web site http://ks.water.usgs.gov/studies/qw/joco Additional discussion regarding quality-assurance samples collected in Johnson County related to this and previous studies can be found in Lee and others (2005) and Rasmussen and others (2008).

\section{Periphyton Data}

Replicate samples for chlorophyll and periphyton community composition, abundance, and biovolume analyses were collected in both March and July. Field split replicate samples for chlorophyll analysis were collected at all sites. Because of the patchy nature of periphyton communities within streams (Stevenson, 1997), the variability among replicate samples may be much greater than for other commonly measured water-quality variables such as water chemistry. Most field split-replicate chlorophyll samples (83 percent) had a coefficient of variation (CV; Sokel and Rohlf, 1995) less than 10 percent, although CVs ranged from 0.3 to 35 percent (mean 9.4 percent, median 6.2 percent). Field split-replicate samples with large CVs likely were caused by clumps of periphytic material that could not be homogenized by vigorous shaking. Concurrent field-replicate chlorophyll samples had a CV of 20 percent in March and 9 percent in July. Concurrent fieldreplicate samples for periphyton community composition, abundance, and biovolume had small CVs in March (less than 5 percent) and large CVs in July (78-87 percent). The difference in CVs among months likely was because of site differences and the patchy nature of the periphyton communities. One laboratory duplicate sample was analyzed for periphyton community composition, abundance, and biovolume. The CVs for this sample were all less than 1 percent.

\section{Macroinvertebrate Data}

Replicate macroinvertebrate samples were collected at 2 of the 20 sites including 1 urban site and 1 rural site. A total of three successive samples were collected from each of the two sites. Metrics were calculated for each sample individually and compared using CV. The mean CV for replicate macroinvertebrate metric values was less than 12 percent except for percentage of scrapers $(\% \mathrm{Sc})$, percentage of Oligochaeta (\%Oligo), percentage of Tanytarsini (\%Tany), and percentage of Ephemeroptera and Plecoptera (\%EP), which ranged from 28 to about 100 percent. The small number of specified organisms in some samples accounted for large variability among replicate samples. An additional source of variability likely was differences in habitat types among the three sampling locations within each stream reach.
Quality assurance and quality control for macroinvertebrate identification and enumeration procedures generally followed those outlined in Moulton and others (2000) and included within-laboratory cross checking of individual samples and specimens. Updated taxonomic keys and voucher specimens are kept on file at the USGS NWQL, Lakewood, Colorado. Other quality-assurance measures included repeats of identification and enumeration procedures on the same sample by different laboratory technicians and a full comparison of bench sheets for a minimum of 10 percent of the samples.

\section{Assessment of Stream Quality}

\section{Environmental Variables}

Environmental variables include stream-water chemistry, streambed-sediment chemistry, streamflow and precipitation, and habitat conditions.

\section{Stream-Water Chemistry}

Water samples were collected during base flow in March the same week other samples were collected. They were analyzed for physical properties, dissolved solids, major ions, nutrients (nitrogen and phosphorus), trace elements, suspended sediment, fecal-indicator bacteria, and organic compounds (table 4, at the back of this report). Data were qualified by the laboratory with estimated or less-than values as described by Childress and others, 1999.

Specific conductance, dissolved solids (reported as filtered residue in table 4), and major ions including calcium, magnesium, sodium, and chloride, varied largely from site to site. Specific conductance is a measurement of dissolved solids in stream water and is determined primarily by the amount of groundwater contributing to streamflow, the amount of urbanization, and discharges from wastewater and industrial sites. Dissolved-solids concentrations ranged from $282 \mathrm{mg} / \mathrm{L}$ in water from the Captain Creek State reference site (CA1) to $1,000 \mathrm{mg} / \mathrm{L}$ in water from one of the headwater Mill Creek streams (site LM1b) (table 4). Four sites with urban land use larger than 77.0 percent, which included the three headwater Mill Creek sites (LM1a, LM1b, LM1c) and the Turkey Creek site (TU1), had the largest concentrations of calcium, sodium, and chloride. Chloride concentration in water from the unnamed Little Mill tributary (cite LM1b, $347 \mathrm{mg} / \mathrm{L}$ ) was more than 25 times the concentration found in water from the Captain Creek (CA1, $12 \mathrm{mg} / \mathrm{L}$ ). Additional sources of ions, particularly chloride, in urban streams include road salt accumulation, runoff over impervious surfaces, discharges from septic systems and water softeners, and stormwater passage through pipes and other infrastructure (Herlihy and others, 1998; Paul and Meyer, 2001; Kaushal and others, 2005). 
The largest nitrogen and phosphorus concentrations occurred downstream from wastewater treatment plants. The water samples from Indian Creek sites (IN3a, IN6) had total nitrogen (calculated by summing nitrite, nitrate, ammonia, and organic nitrogen) concentrations larger than $7.00 \mathrm{mg} / \mathrm{L}$ and total phosphorus concentrations larger than $1.00 \mathrm{mg} / \mathrm{L}$ (table 4). The water samples from Mill Creek at 87th Lane (site MI4) had a total nitrogen concentration of $5.46 \mathrm{mg} / \mathrm{L}$ and a total phosphorus concentration of $0.66 \mathrm{mg} / \mathrm{L}$. Total nitrogen and total phosphorus concentrations in water samples from the remaining sites were less than or equal to 3.0 and $0.25 \mathrm{mg} / \mathrm{L}$, respectively.

The largest iron concentrations occurred in water samples from rural sites on Captain Creek (site CA1) and Kill Creek (site KI5b, 40 micrograms per liter $(\mu \mathrm{g} / \mathrm{L}$ ) at each site, table 4). Manganese had the largest concentrations $(240 \mu \mathrm{g} / \mathrm{L})$ in water from a highly urbanized sampling site (TU1) and from a rural stream (site BI1, also $240 \mu \mathrm{g} / \mathrm{L}$ ). The zinc concentration in water from the urban site IN3a (the largest concentration at $26 \mu \mathrm{g} / \mathrm{L}$ ) was 13 times larger than the smallest concentration in the water from an upstream Blue River site (BL4, $2 \mu \mathrm{g} / \mathrm{L}$ ).

Suspended-sediment concentration, which can reduce light penetration and photosynthesis and smother benthic habitats (Devlin and McVay, 2001), ranged from 4 to $72 \mathrm{mg} / \mathrm{L}$ (table 4). Water from rural sites in the Blue River watershed (sites BL3, BL4, BL5) had the largest suspended-sediment concentrations, and water from sites downstream from WWTFs on Indian (sites IN3a, IN6) and Mill (sites MI1, MI4) Creeks had the smallest concentrations. The range in fecalindicator bacteria densities among sites was not substantial. Of the pesticides analyzed, atrazine had the largest concentration, and it occurred in a water sample from Big Bull Creek (site BI1, $0.508 \mu \mathrm{g} / \mathrm{L})$.

\section{Streambed-Sediment Chemistry}

Streambed-sediment samples were analyzed for carbon, nutrients, trace elements, and organic compounds (table 5, at the back of this report). Analysis was done only on the fraction of the sediment sample with particles less than $63 \mu \mathrm{m}$ in diameter (silt and clay size) to avoid sediment-size effects on chemical concentrations. Data were qualified by the laboratory with estimated or less-than values as described by Childress and others, 1999.

The upstream Cedar Creek site (CE1) had the largest concentrations of nearly all trace metals and nutrients including phosphorus $(1,100$ milligrams per kilogram $(\mathrm{mg} / \mathrm{kg}))$, and trace metals such as barium $(1,100 \mathrm{mg} / \mathrm{kg})$, chromium $(120$ $\mathrm{mg} / \mathrm{kg}$ ), copper (38 mg/kg), nickel (53 mg/kg), and zinc (200 $\mathrm{mg} / \mathrm{kg}$ ) all of which were about double the median concentrations of all sites (table 5). Barium, beryllium, chromium, copper, and titanium concentrations in 2007 were more than double the concentrations reported in 2003, but aluminum decreased in 2007 to about one quarter of the 2003 value (Lee and others, 2005). There are no criteria for trace metals, but the probable effect concentrations (PEC) of 111 and $48.6 \mathrm{mg} /$ $\mathrm{kg}$, respectively (MacDonald and others, 2000), for chromium and nickel were exceeded at site CE1. The PEC represents the concentration of a contaminant in streambed sediment that is expected to adversely affect benthic biota. Both chromium and nickel are carcinogenic and mutagenic (U.S. Environmental Protection Agency, 2008) and are common metals in industrial and urban runoff. Chromium inhibits growth in algae and reduces survival of benthic macroinvertebrates, and nickel damages tissues and reduces growth (U.S. Environmental Protection Agency, 2008).

Twenty of the 23 nutrient and trace element constituents analyzed in streambed sediment decreased in 2007 compared to 2003 (Lee and others, 2005) at the Big Bull Creek site (BI1, table 5). In 2007, several constituents in streambed sediment at site BI1, including carbon, nitrogen, and phosphorus were about one-fourth of the values reported in 2003. Nitrogen and phosphorus concentrations in streambed sediment at Indian Creek sites IN3a and IN6, both downstream from wastewater discharges, also were less than the values reported in 2003 (table 5), particularly at site IN3a where nutrient values in 2007 were one-third to one-fourth the values in 2003 (Lee and others, 2005).

Fifty-eight organic compounds (pesticides and wastewater) were analyzed in streambed sediment, and 26 of them were detected at concentrations larger than the laboratory reporting level (table 5). Wastewater compounds detected included polycyclic aromatic hydrocarbons (PAHs), detergent metabolites, phenols, sterols, plant and animal steroids, disinfectants, antimicrobials, flame retardants, and plasticizers.

PAHs were detected at about one-half of the biological sampling sites, in mostly urban areas. PAHs analyzed included anthracene, benzo(a)pyrene, fluoranthene, naphthalene, phenanthrene, and pyrene. The largest PAH concentrations in streambed sediment occurred in Turkey Creek (site TU1), Indian Creek (sites IN1b, IN6), upstream Mill Creek (site MI1), and two headwater Little Mill Creek sites (LM1b, LM1c). The probable effect concentration (MacDonald and others, 2000) for fluoranthene $(2,230 \mu \mathrm{g} / \mathrm{kg})$, phenanthrene $(1,170 \mu \mathrm{g} / \mathrm{kg})$, and pyrene $(1,520 \mu \mathrm{g} / \mathrm{kg})$ were exceeded in streambed sediment at most of the sampling sites where they were detected. Concentrations were similar to those found in 2003 (Lee and others, 2005).

PAHs originate from the incomplete combustion of fossil fuels. A common source of PAHs in urban areas is coal-tar sealcoats that are applied to parking lots (Mahler and others, 2005). Mahler and others (2005) found that sediment particles in runoff directly from parking lots with coal tar sealants had a mean PAH concentration of 3,500,000 $\mu \mathrm{g} / \mathrm{kg}$. PAHs are known carcinogens and have wide-ranging effects on organisms (Eisler, 1987). Analysis of macroinvertebrate communities in watersheds affected by increased PAH concentrations from coal-tar parking lot sealants indicated significant decreases in community health including species richness and abundance of intolerant species (Scroggins and others, 2007). Effects on benthic macroinvertebrates include inhibited reproduction, delayed emergence, and higher mortality rates, and for fish 
include fin erosion, liver abnormalities, cataracts, and immune system impairments (U.S. Environmental Protection Agency, 2008). The PEC for total PAHs is $22,800 \mu \mathrm{g} / \mathrm{kg}$ (MacDonald and others, 2000) and was not exceeded for the PAHs that were analyzed at any biological sampling sites.

Nonylphenol compounds, which originate from surfactants and detergents, are toxic to some aquatic organisms and in 2005 the USEPA established criteria for nonylphenol in water (U.S. Environmental Protection Agency, 2005). Nonylphenol compounds analyzed include octylphenol ethoxylates, 4-nonylphenol, and 4-nonylphenol diethoxylate. The largest concentration of total nonylphenol compounds occurred in streambed sediment from the upstream Mill Creek site (less than $4,100 \mu \mathrm{g} / \mathrm{kg}$, site MI1, table 5). This is in contrast to 2003 results when the largest detections of nonylphenol compounds were in samples from Indian Creek Sites IN3a and IN6, which are directly downstream from wastewater discharges (Lee and others, 2005). The smallest concentrations occurred at the urban Turkey Creek (TU1, less than 730) and Indian Creek (IN3a, less than $740 \mu \mathrm{g} / \mathrm{kg}$ ).

The overall range in concentrations of other wastewater compounds in streambed sediment was not markedly different in 2007 compared to 2003, but individual site concentrations varied. For example, the concentration of para-cresol, a wood preservative, in 2003 (Lee and others, 2005) was largest at Indian Creek site IN3a $(6,300 \mu \mathrm{g} / \mathrm{kg})$ but was only $440 \mu \mathrm{g} /$ $\mathrm{kg}$ in 2007. The largest para-cresol concentration in 2007 occurred in streambed sediment from the Blue River site BL4 $(6,400 \mu \mathrm{g} / \mathrm{kg})$, a site that was not sampled in 2003 but nearby Blue River sites (BL3 and BL5) had concentrations of 32 and $110 \mu \mathrm{g} / \mathrm{kg}$, respectively (Lee and others, 2005). The largest concentration of carbazole, a compound used in dyes, occurred in streambed sediment from Turkey Creek (site TU1, $760 \mu \mathrm{g}$ / $\mathrm{kg}$ ) in 2007 , but it was only $55 \mu \mathrm{g} / \mathrm{kg}$ in 2003 . The largest coprostanol (3-beta-coprostanol in table 5) concentrations in 2007 occurred in streambed sediment from Indian Creek sites IN6 $(13,000 \mu \mathrm{g} / \mathrm{kg})$ and IN3a $(2,200 \mu \mathrm{g} / \mathrm{kg})$, the sites nearest to wastewater discharges. But in 2003, site IN3a had the largest concentration $(10,000 \mu \mathrm{g} / \mathrm{kg})$ followed by site IN6 $(5,500$ $\mu \mathrm{g} / \mathrm{kg}$ ) (Lee and others, 2005). Concentrations of wastewater compounds in streambed sediment may differ from 2003 to 2007 because of changes in sources within the watershed, differences in hydrologic conditions, and variability in sampling and analysis.

\section{Watershed Variables-Streamflow and Precipitation}

Biological samples were collected early in spring, prior to the onset of typical spring runoff. However, several small periods of precipitation amounts occurred during January through March 2007 that may have affected biological communities. In particular, four increasingly larger streamflow pulses occurred between February 12 and March 4, 2007, at most biological sampling sites in the county. At the downstream Mill Creek site (MI7) for example (fig. 3), streamflow exceeded 100 cubic feet per second $\left(\mathrm{ft}^{3} / \mathrm{s}\right)$ during the first three pulses and exceeded 2,000 ft $3 / \mathrm{s}$ during the fourth pulse. A peak streamflow of $2,000 \mathrm{ft}^{3} / \mathrm{s}$ may have resulted in some scouring, but it is smaller than the estimated 2-year peak streamflow of 7,700 $\mathrm{ft}^{3} / \mathrm{s}$ (Perry and others, 2004). Other water-quality variables (such as specific conductance, water temperature, turbidity, dissolved oxygen, nutrients, and others) also fluctuated and may have temporarily affected biological communities (fig. 3). The time required for biological communities to re-establish following periods of runoff varies. Murdock and others (2004) found that precipitation of $0.5 \mathrm{in}$. resulted in periphyton reset and that biomass could re-accumulate to nuisance levels within 5 days regardless of the season.

Mean daily streamflow prior to collecting samples in 2007 is compared to 2003 and 2004 when samples were collected previously at two Johnson County biological sampling sites in figure 4. Samples were collected March 4-13, 2003, February 24-March 3, 2004, and March 12-16, 2007. Samples were collected in 2004 prior to the large runoff on March 4. Although some small rises in streamflow are evident in 2003 and 2004, the streamflow pulses in 2007 were larger and more frequent except for the pulse on March 4, 2004 (fig. 4).

Statistical streamflow metrics, used as variables in correlation analysis, were determined for 7 of the 20 biological sampling sites where streamflow data were available (table 6). Out of the more than 100 different streamflow metrics that were calculated using different methods and periods of record, 18 metrics were selected that affected stream ecosystems in different ways, differentiated between sites, and represented minimal redundancy. The streamflow metrics used in the final analyses of relations among stream quality and watershed variables were calculated using only data from 2005-07 to include periods of record that were consistent between sites.

\section{Habitat}

Total habitat scores (the sum of the 17 scores for individual habitat variables) ranged from the least optimal score of 88 for the Turkey Creek site (TU1) to the most optimal score of 152 for the upstream Kill Creek site (KI5b, table 7). Except for urban sites at Indian Creek (site IN6) and Turkey Creek (site TU1) which scored poorly (99 and 88, respectively), the range in total habitat scores between remaining sites was fairly narrow, about 120 to 150 . The low total habitat score for the downstream Indian Creek site (IN6) primarily was the result of poor to suboptimal bank and riparian conditions. Although the buffer width for the Turkey Creek site (TU1) also scored poorly, the overall low habitat score was more a result of poor to suboptimal channel conditions associated with channelization at this site. The total habitat score for the Tomahawk Creek site (TO2) was relatively high (135) considering 79 percent of the land use is urban. Streamway parks on Tomahawk Creek have provided protection of riparian areas near that site, and some eroding banks have been artificially reveted 

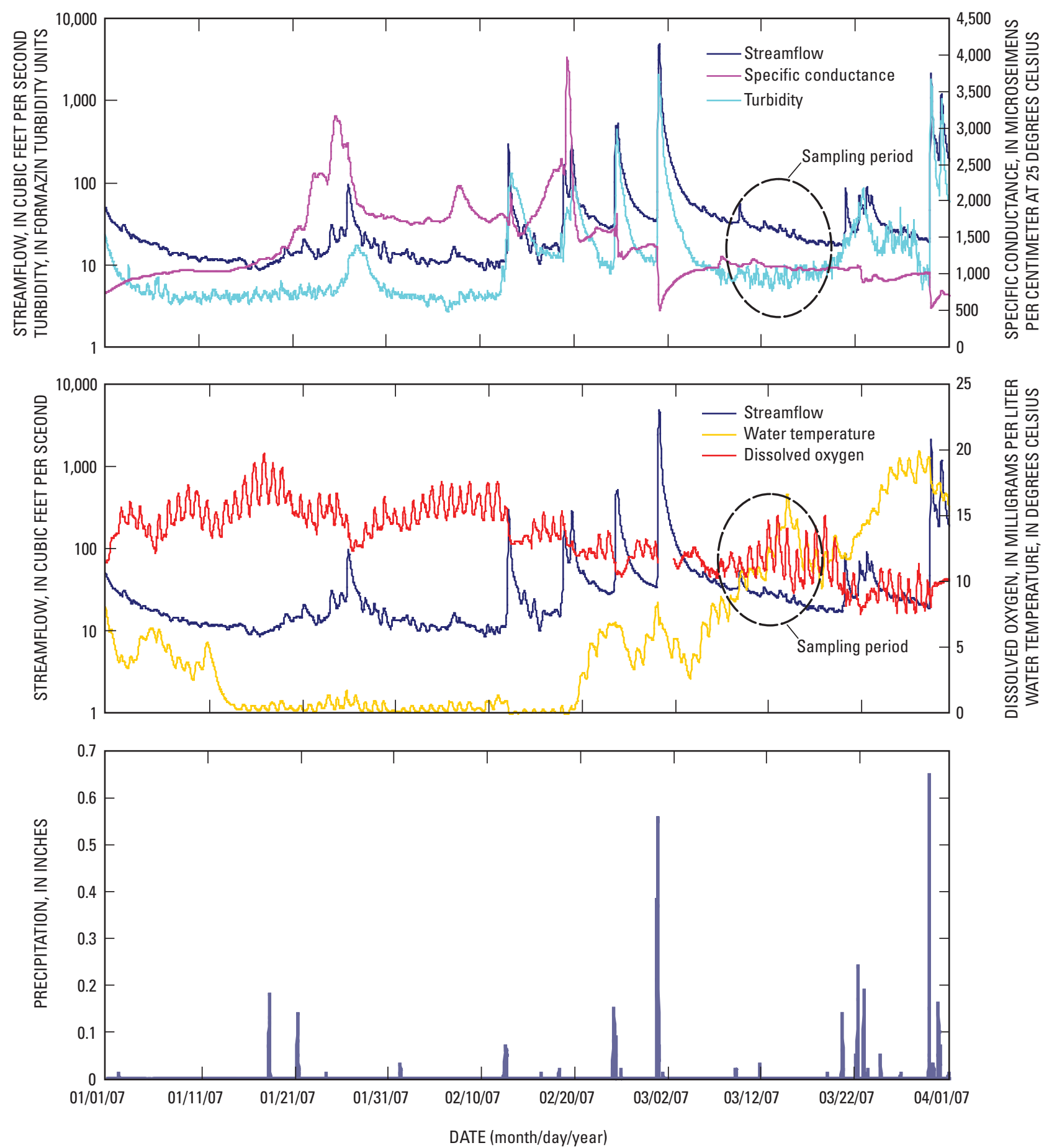

Figure 3. Streamflow, specific conductance, water temperature, dissolved oxygen, turbidity, and precipitation prior to collection of samples from downstream Mill Creek site MI7 in Johnson County, Kansas, January 1-April 1, 2007 (http:// nrtwq.usgs.gov/ks//.

and stabilized with rock. The Blue River at Kenneth Road (site BL5) and the two Kill Creek sites (KI5b, KI6b) had the highest total habitat scores. Unexpectedly, the State reference site on Captain Creek (site CA1) ranked the third lowest in overall habitat conditions, primarily because of lower scores for individual habitat variables related to sediment deposition and bank instability.

The total habitat scores for each site were compared to habitat scores calculated using just the 10 variables included in the USEPA's Rapid Habitat Assessment Protocol (RHAP; Barbour and others, 1999) (table 7). The protocol used for 
A. Blue River near Stanley, Kansas (06893080, site BL3, fig. 1), November 1-March 15

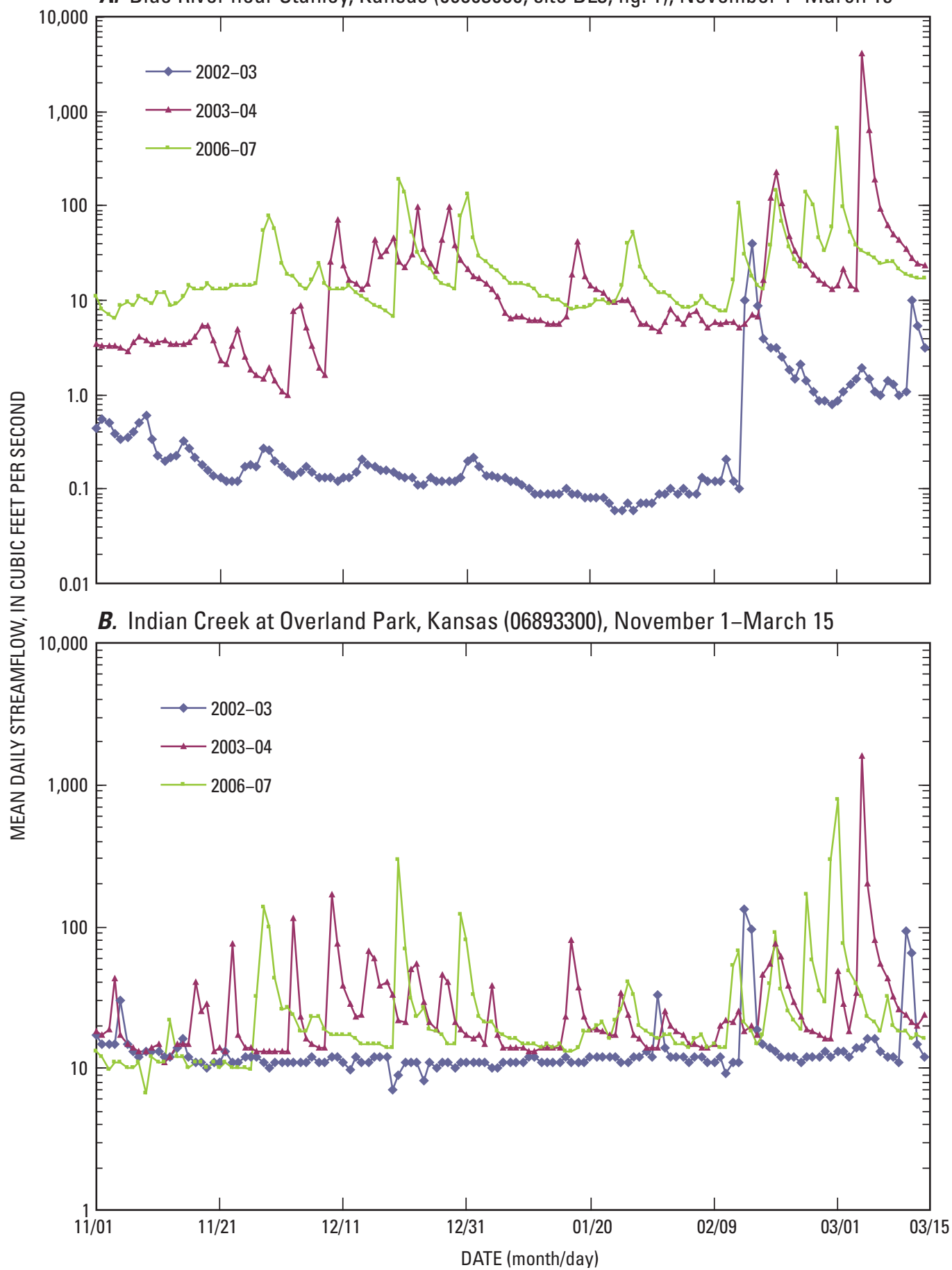

Figure 4. Mean daily streamflow in the Blue River and Indian Creek in Johnson County, Kansas, prior to collection of samples in 2003, 2004, and 2007 (http://nrtwq.usgs.gov/ks/).

this study included habitat variables similar (in some cases identical) to the RHAP variables but also included seven additional variables that were expected to better differentiate among urban streams. The Spearman's correlation coefficient (rho) for the two habitat scores was 0.89 (p-value less than 0.001 ), which indicates that they produced similar results.
Site rankings that are based on the two scores (table 7) also produced similar results except that the two upstream Indian Creek sites (IN1b, IN3a) and Tomahawk Creek site (TO2) ranked less favorably with the RHAP protocol, and three sites in the Mill Creek watershed (two of the Little Mill headwater stream sites, LM1a and LM1b, and the upstream Mill Creek site, MI1) ranked better using the RHAP protocol. 
Table 6. Streamflow statistics used in correlation analysis for biological sampling sites in Johnson County, Kansas, 2005-07. $\left[\mathrm{mi}^{2}\right.$, square miles; $\mathrm{ft}^{3} / \mathrm{s}$, cubic feet per second; $\left(\mathrm{ft}^{3} / \mathrm{s}\right) / \mathrm{mi}^{2}$, cubic feet per second per square mile; $\left(\mathrm{ft}^{3} / \mathrm{s}\right) / \mathrm{d}$, cubic feet per second per day]

\begin{tabular}{|c|c|c|c|c|c|c|c|}
\hline \multirow[b]{2}{*}{ Streamflow statistic } & \multicolumn{7}{|c|}{ Biological sampling site (fig. 1) } \\
\hline & 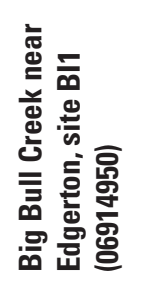 & 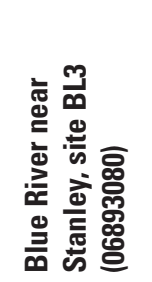 & 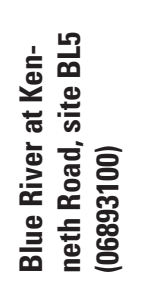 & 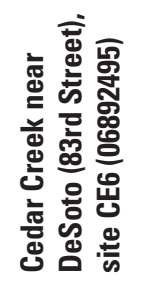 & 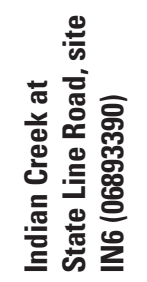 & 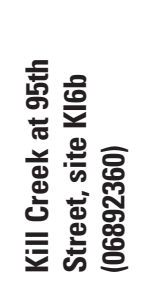 & 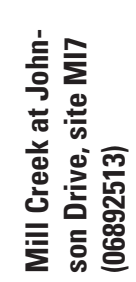 \\
\hline Watershed area, $\mathrm{mi}^{2}$ & 26.5 & 46.5 & 65.7 & 58.5 & 63.1 & 48.6 & 57.4 \\
\hline Mean daily streamflow/area, $\left(\mathrm{ft}^{3} / \mathrm{s}\right) / \mathrm{mi}^{2}$ & 1.89 & .75 & .69 & .66 & 1.40 & .49 & .82 \\
\hline Median monthly streamflow, January, $\mathrm{ft}^{3} / \mathrm{s}$ & 2.5 & 6.2 & 18 & 15 & 35 & 4.3 & 14 \\
\hline Median monthly streamflow, February, $\mathrm{ft}^{3} / \mathrm{s}$ & 4.1 & 10 & 16 & 14 & 43 & 4.4 & 18 \\
\hline Base-flow index, unitless & .109 & .135 & .159 & .261 & .263 & .197 & .222 \\
\hline Low pulse count, number of events per year & 8 & 5 & 9 & 9 & 17 & 6 & 12 \\
\hline High pulse count, number of events per year & 13 & 14 & 16 & 17 & 33 & 15 & 25 \\
\hline Low pulse threshold, $\mathrm{ft}^{3} / \mathrm{s}$ & 1.1 & .9 & 5.5 & 5.8 & 25 & 1.5 & 8.4 \\
\hline High pulse threshold, $\mathrm{ft}^{3} / \mathrm{s}$ & 8.3 & 18 & 27 & 25 & 57 & 12 & 30 \\
\hline Rise rate, $\left(\mathrm{ft}^{3} / \mathrm{s}\right) / \mathrm{d}$ & .69 & 1.1 & 2.3 & 2.0 & 27 & 0.85 & 10 \\
\hline Fall rate, $\left(\mathrm{ft}^{3} / \mathrm{s}\right) / \mathrm{d}$ & -.5 & -1 & -3 & -3 & -7 & -1 & -3 \\
\hline Mininum 7-day average streamflow, $\mathrm{ft}^{3} / \mathrm{s}$ & .35 & .25 & .43 & 3.22 & 18.57 & .58 & 4.81 \\
\hline Maximum daily streamflow, $\mathrm{ft}^{3} / \mathrm{s}$ & 1,880 & 2,170 & 3,760 & 2,495 & 3,080 & 2,320 & 1,870 \\
\hline Mean daily streamflow, $\mathrm{ft}^{3} / \mathrm{s}$ & 23.1 & 38.3 & 56.3 & 44.3 & 90.7 & 32.7 & 52.9 \\
\hline Standard deviation of daily streamflow, unitless & 110 & 151 & 224 & 137 & 239 & 125 & 144 \\
\hline Coefficient of variability, unitless & 4.74 & 3.95 & 3.98 & 3.09 & 2.63 & 3.84 & 2.72 \\
\hline Ratio of 75 th to 25 th percentile, unitless & 5.38 & 5.29 & 6.95 & 3.51 & 2.51 & 5.93 & 3.28 \\
\hline 90th minus 10 th $/ 50$ th percentile, unitless & 8.26 & 7.24 & 6.05 & 4.48 & 4.71 & 6.86 & 5.03 \\
\hline
\end{tabular}

\section{Biological Variables}

Stream quality was evaluated on the basis of biological variables describing periphyton and macroinvertebrate communities.

\section{Periphyton Communities}

The attached algae that grow on submerged surfaces in streams, such as rocks and woody debris, commonly are referred to collectively as periphyton. Periphyton are at the base of the food web in stream ecosystems and serve as a primary link between abiotic (non-living) factors, such as nutrients, and higher trophic levels (higher place in food web), such as macroinvertebrate communities. Algae have short life cycles and respond rapidly to changes in environmental conditions; thus, periphyton communities often are the first to respond to and recover from floods or contaminant pulses (Allan, 1995; Rosen, 1995; Lowe and Pan, 1996; Lowe and LaLiberte, 2007). Physical, chemical, and pollution tolerances and growth optima have been described for many periphytic algal species, which allows periphytic communities to be used as indicators of ecological conditions. The State of Kansas currently (2009) does not use periphyton in biological assessments of water quality, but several States, including Kentucky (Kentucky Division of Water, 1993), Montana (Bahls, 1993), and Oklahoma (Oklahoma Conservation Commission, 1993), use periphyton in their bioassessment programs.

\section{Community Composition}

Overall, 92 periphyton taxa were identified from the 11 sites that were sampled in Johnson County during 2007 (Appendix 2). The majority of the taxa present (80) were in the division Bacillariophyta (diatoms); there were 7 taxa in the division Chlorophyta (green algae), 4 taxa in the division Cyanophyta (cyanobacteria or blue-green algae), and 1 taxon in the division Euglenophyta (euglenoids). Of the 92 taxa identified, 21 were collected in March 2007 only, 38 in July only, and 33 in both March and July. About one-half (52 percent) of the taxa observed were relatively rare [observed at only one or two sites or contributing less than 1 percent to total periphyton abundance and (or) biovolume], and only 9 taxa were observed at more than 50 percent of the sites in 


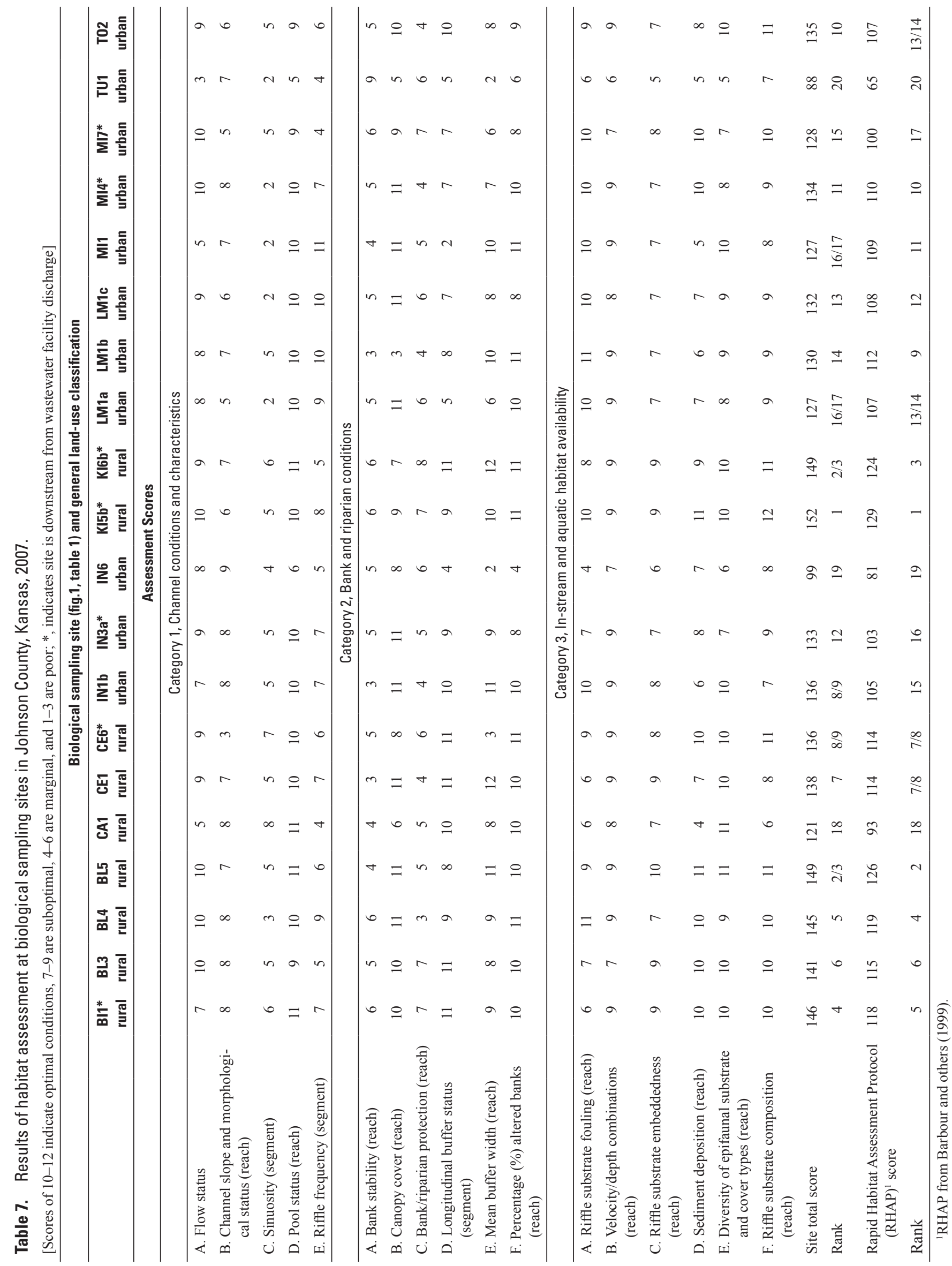


both March and July. On the basis of taxa occurrence, the four most common periphyton taxa were the diatoms Diadesmus perpusilla, Navicula subminuscula, Nitzchia inconspicua, and Nitzchia perminuta. These taxa generally are indicative of somewhat degraded, mesoeutrophic conditions with small to moderate amounts of organic enrichment (Porter, 2008).

Periphyton abundance and biovolume at all sites during both March and July 2007 were dominated (greater than 75 percent of total) by diatoms (Bacillariophyta) with the exception of biovolume at Tomahawk Creek (site TO2) in March when cyanophyta were dominant (57 percent of total biovolume) (table 8). Diatoms most commonly dominate periphyton communities, but under certain conditions green algae (chlorophyta) and cyanobacteria (cyanophyta) also may occur. In streams, green algae and cyanobacteria are most likely to occur during summer when temperatures are warmer and flows tend to be at seasonal lows (Allan, 1995; Stevenson and Rollins, 2007). Green algae were common and contributed to a larger percentage (as much as about 20 percent) of total abundance and biovolume at most sites in July (table 8). Cyanobacteria generally are considered a nuisance when present because of the potential for production of toxins and taste-and-odor compounds (Graham and others, 2008). In streams, dominance by cyanobacteria typically is indicative of enrichment by nutrients and organic compounds (Stevenson and Rollins, 2007). Cyanobacteria contributed less than 1 percent to total periphyton abundance except at Indian Creek sites IN3a and IN1b and Tomahawk Creek site TO2 where cyanobacteria contributed less than 3 percent. Cyanobacteria contributed less than 1 percent to total periphyton biovolume except at the Tomahawk Creek site TO2 in March (table 8).

\section{Periphyton Chlorophyll Concentrations, Abundance, and Biovolume}

Chlorophyll, a light-gathering pigment present in all photosynthetic organisms, often is used to describe algal communities because it is simpler and less time consuming than identifying, counting, and measuring algal cells. Periphyton abundance reflects the total number of cells present, whereas chlorophyll concentrations and biovolume are indicators of periphyton biomass. Biovolume is calculated using measured cell dimensions and algal abundance (Blomqvist and Herlitz, 1998; Olrik and others, 1998). Nuisance algal conditions have been suggested to occur when periphytic chlorophyll concentrations exceed 100 milligrams per square meter $\left(\mathrm{mg} / \mathrm{m}^{2}\right)$ (Horner and others, 1983; Welch and others, 1988; Lohman and others, 1992); similar threshold concentrations have not been established for periphytic algal abundance and biovolume.

March 2007 total chlorophyll concentrations ranged from 16.2 to $132.0 \mathrm{mg} / \mathrm{m}^{2}$ (mean $82.1 \mathrm{mg} / \mathrm{m}^{2}$ ), whereas July 2007 chlorophyll concentrations ranged from 7.5 to $124.9 \mathrm{mg} / \mathrm{m}^{2}$ (mean $27.3 \mathrm{mg} / \mathrm{m}^{2}$ ) (table 9; fig. 5A). Chlorophyll concentrations were significantly larger in March than in July (p-value < 0.01). Chlorophyll concentrations were larger at all sampling sites in March, with the exception of site IN6. At most sites chlorophyll concentrations were at least three to five times larger in March than July. During March, 45 percent of sites had chlorophyll concentrations close to or exceeding the chlorophyll nuisance threshold value of $100 \mathrm{mg} / \mathrm{m}^{2}$ (table 9, fig. 5A). Sites with chlorophyll concentrations close to or exceeding the nuisance threshold in March spanned the range of physical and chemical conditions among sampling sites and included rural sites (CA1 and BL5), moderately urban sites (CE6 and MI7), and urban site IN3a. In July, chlorophyll only exceeded the nuisance threshold at Indian Creek at State Line (site IN6); concentrations were substantially less than the nuisance threshold at all other sites.

Seasonal patterns in periphyton abundance and biovolume were similar to chlorophyll concentrations (table 9, fig. $5 B$ and $5 C$ ). With all sites grouped together, periphyton abundance and biovolume were significantly larger in March 2007 than July 2007 (abundance, p-value $=0.01$; biovolume, $\mathrm{p}$-value $=0.02$ ). The largest periphyton abundance and biovolume occurred at most sites in March, but like chlorophyll, abundance and biovolume in Indian Creek at State Line Road (site IN6) were largest in July. Periphyton abundance in Tomahawk Creek (site TO2) in March was four times larger than in July. In contrast, biovolume was two orders magnitude larger in July than March (table 9, fig. 5B and $C$ ). The discrepancy between abundance and biovolume at site TO2 is likely because of dominance by cyanobacteria in March (table 8). Abundance and biovolume were similar during both months at the downstream Kill Creek site (KI6b, table 9, fig. 5B and C).

Flow regime has a substantial effect on algal biomass because the frequency between floods dictates the amount of time available for algal accumulation (Lohman and others, 1992; Murdock and others, 2004). However, algal biomass may recover rapidly (within days) after flooding (Murdock and others, 2004). Light also is a key factor limiting periphyton growth in temperate streams; periphyton biomass may decrease during summer because of increased shading (Allan, 1995). Flooding did not occur in the 2 weeks prior to the March and July sampling. Thus, light limitation is the most likely explanation for the smaller periphyton chlorophyll concentrations, abundance, and biovolume in July.

In March 2007, the four dominant taxa at each site comprised 49 to 88 percent of total abundance and 37 to 95 percent of total biovolume (Appendixes 3 and 4). On the basis of abundance, the most common taxa were Surirella bresbissonii, Gomphoneis olivaceum, Nitzschia dissipatas, and Diadesmus perpusilla. On the basis of biovolume, the most common taxa were Surirella bressbisonii, Gomphoneis olivaceum, Fragilaria capucina, and Synedra ulna (Appendix 3).

In July 2007, the four most dominant taxa at each site comprised 44 to 90 percent of the total abundance and 58 to 95 percent of total biovolume (Appendixes 3 and 4). On the basis of abundance, the most common taxa were Diadesmis perpusilla, Navicula margalithii, Cocconeis placentula, Cladophora glomerata, and Navicula subminuscula. On the basis of biovolume, the most common taxa were Diadesmus 


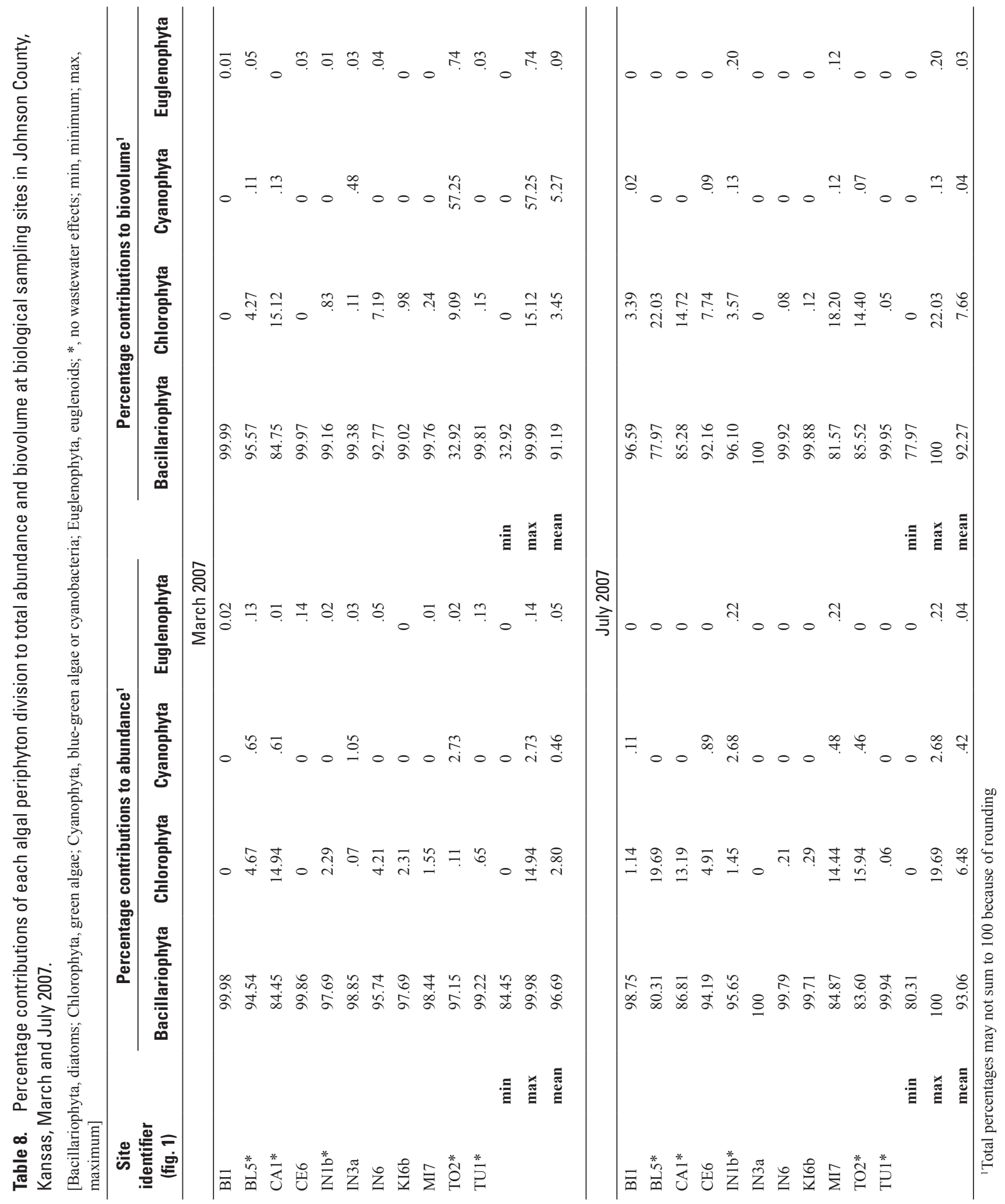



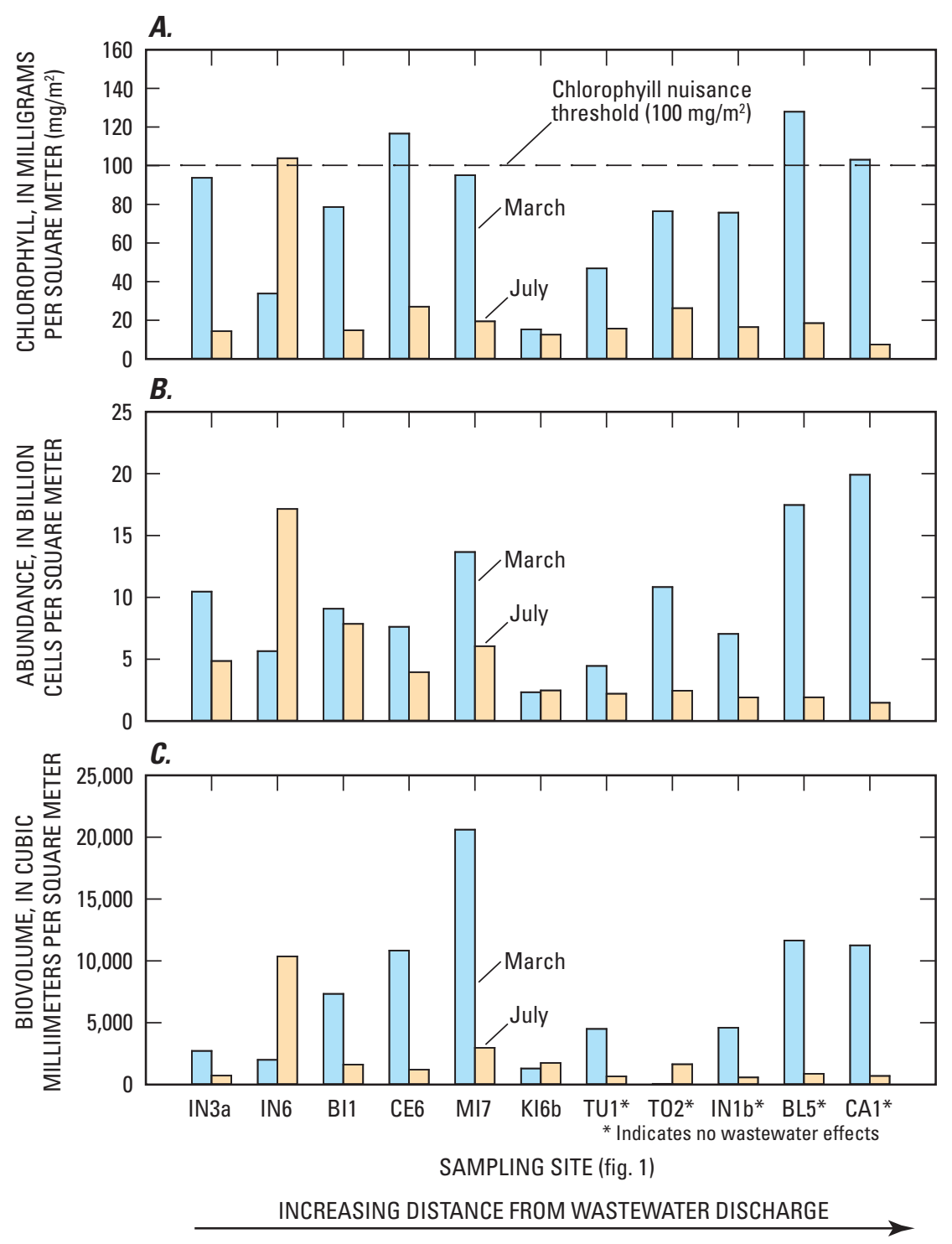

Figure 5. Algal periphyton $(A)$ chlorophyll concentrations, $(B)$ abundance, and $(C)$ biovolume at biological sampling sites in Johnson County, Kansas, March and July 2007.

perpusilla, Cocconeis placentula, and Cladophora glomerata. All of the most common taxa generally were indicative of somewhat degraded, meso-eutrophic conditions with small to moderate amounts of organic enrichment (Porter, 2008).

\section{Periphyton Metrics}

Three diatom metrics and eight additional community metrics were calculated for periphyton using total biovolume and are discussed in this section.

\section{Eutraphentic Diatoms}

Eutraphentic diatoms are indicative of increased nutrient conditions in streams (Stevenson and Rollins, 2007). Eutraphentic diatoms comprised 4.1 to 71.0 percent of total periphyton biovolume in March 2007 and 17.5 to 54.7 percent in July 2007 (table 10). The percentage of eutraphentic diatoms was the only calculated metric that showed significant patterns among sampling sites. Sites downstream from wastewater discharge (sites IN3a, IN6, BI1, CE6, MI7, and KI6b) had a significantly larger (Wilcoxon two-sample test, $z=-2.01$, p-value $=0.02$; Sokal and Rohlf, 1995) percentage of eutraphentic diatoms in March than sites not affected by wastewater (sites TU1, TO2, IN1b, CA1) (table 10, fig. 6). Although there was a significant difference in percentage of eutraphentic diatoms, periphyton chlorophyll concentrations, abundance, and biovolume were not significantly different when comparing sites affected by wastewater discharge to other sites (Wilcoxon, all $\mathrm{p}$-values greater than or equal to 0.25 ) (tables 9 and 10, figs. 5 and 6). In addition, March total, 
Table 9. Algal periphyton chlorophyll concentrations, abundance, and biovolume at biological sampling sites in Johnson County, Kansas, March and July 2007.

$\left[{ }^{*}\right.$, no wastewater effects; $\mathrm{mg} / \mathrm{m}^{2}$, milligrams per square meter; $\mathrm{mm}{ }^{3} / \mathrm{m}^{2}$, cubic millimeters per square meter, min, minimum; max, maximum]

\begin{tabular}{|c|c|c|c|c|}
\hline \multirow{2}{*}{$\begin{array}{c}\text { Site } \\
\text { identifier } \\
\text { (fig. 1) }\end{array}$} & & \multicolumn{3}{|c|}{ Algal periphyton } \\
\hline & & $\begin{array}{l}\text { Chlorophyll } \\
\text { concentra- } \\
\text { tions }\left(\mathrm{mg} / \mathrm{m}^{2}\right)\end{array}$ & $\begin{array}{c}\text { Abundance } \\
\text { (billion cells/ } \\
\mathbf{m}^{2} \text { ) }\end{array}$ & $\begin{array}{c}\text { Biovolume } \\
\left(\mathrm{mm}^{3} / \mathrm{m}^{2}\right)\end{array}$ \\
\hline \multicolumn{5}{|c|}{ March 2007} \\
\hline BI1 & & 78.6 & 9.56 & 9,376 \\
\hline BL5* & & 127.9 & 18.30 & 12,633 \\
\hline $\mathrm{CA} 1 *$ & & 113.8 & 20.30 & 11,763 \\
\hline CE6 & & 132.0 & 7.87 & 12,086 \\
\hline IN1b* & & 77.4 & 7.30 & 4,839 \\
\hline IN3a & & 95.3 & 11.50 & 3,470 \\
\hline IN6 & & 38.8 & 6.17 & 2,247 \\
\hline KI6b & & 16.2 & 2.65 & 1,649 \\
\hline MI7 & & 97.2 & 15.00 & 32,533 \\
\hline $\mathrm{TO} 2 *$ & & 78.4 & 11.10 & 62 \\
\hline TU1* & & 47.4 & 4.45 & 4,493 \\
\hline & $\min$ & 16.2 & 2.65 & 62 \\
\hline & $\max$ & 132.0 & 20.30 & 32,533 \\
\hline & mean & 82.1 & 10.38 & 8,650 \\
\hline \multicolumn{5}{|c|}{ July 2007} \\
\hline BI1 & & 15.7 & 7.99 & 1,669 \\
\hline BL5* & & 18.5 & 2.46 & 1,279 \\
\hline $\mathrm{CA} 1 *$ & & 7.5 & 1.87 & 980 \\
\hline CE6 & & 27.0 & 4.38 & 1,506 \\
\hline IN1b* & & 18.6 & 2.25 & 855 \\
\hline IN3a & & 15.2 & 5.83 & 1,002 \\
\hline IN6 & & 124.9 & 19.40 & 12,213 \\
\hline KI6b & & 12.7 & 2.75 & 2,033 \\
\hline MI7 & & 19.7 & 6.50 & 3,333 \\
\hline TO2* & & 24.6 & 2.73 & 1,842 \\
\hline \multirow[t]{4}{*}{ TU1* } & & 15.9 & 2.23 & 672 \\
\hline & $\min$ & 7.5 & 1.87 & 672 \\
\hline & $\max$ & 124.9 & 19.40 & 12,213 \\
\hline & mean & 27.3 & 5.31 & 2,489 \\
\hline
\end{tabular}

dissolved, and reactive phosphorus concentrations were an order of magnitude larger (Wilcoxon, all p-values less than $0.01)$ at sites downstream from wastewater discharges than at other sites (table 4). Thus, phosphorus likely affected algal community composition but not overall biomass in March (Steinman and others, 2006).

The opposite pattern in eutraphentic diatoms was observed in July 2007. Generally, sites with no wastewater effects had a larger percentage of eutraphentic diatoms than sites with wastewater effects (table 10, fig. 6), although the difference was not significant (Wilcoxon test, $\mathrm{z}=1.46$, $\mathrm{p}$-value $=0.07$ ). However, despite a larger proportion of eutraphentic diatoms, overall periphyton abundance and biovolume were significantly less (Wilcoxon, all p-values less than or equal to 0.02 ) at sites with no wastewater effects (tables 9 and 10, figs. 5 and 6). During summer months, nutrients are more likely to be limiting in streams if flood frequency is less. Therefore, the amount of time for algal accumulation, and subsequent nutrient limitation, is larger (Lohman and others, 1992; Murdock and others, 2004). However, it is unknown if and when nutrients limit periphyton growth in Johnson County streams. Differences in community structure and composition between March and July 2007 may be a result of changing nutrient and (or) light conditions.

\section{Other Calculated Metrics}

Species of Navicula generally are considered to be indicators of ecosystem disturbance, and species of Nitzchia generally are considered to be pollution tolerant (Stevenson and Rollins, 2007). Navicula represented as much as 28.1 percent of total biovolume at all sites in March 2007, with maximum values observed at Captain Creek (site CA1) and Indian Creek at State Line Road (site IN6). Contributions to overall biovolume generally increased in July 2007, with Navicula representing as much as 61.9 percent of total biovolume (table 10). The percentage Nitzchia at all sites during March and July ranged from about 1 to 28 percent of total biovolume. The Indian Creek site (IN6) showed the largest change in percentage Navicula and Nitzchia between March and July. In March, Navicula and Nitzchia together represented approximately 50 percent of the total periphyton biovolume at site IN6; in July they represented less than 5 percent (table 10). Overall, site IN6 had the largest shift in community composition between March and July 2007. Dominance by Navicula, Nitzchia, and eutraphentic taxa in March shifted to dominance by the diatom Cyclotella in July (76 percent of total biovolume; (Appendix 4)). Cyclotella was not included in metric calculations. Cyclotella generally is considered to favor nutrient-enriched conditions and to be somewhat tolerant of degraded conditions (Porter, 2008).

Motile taxa are indicative of sedimentation (Stevenson and Rollins, 2007). The largest percentage of motile taxa was observed at Turkey Creek (site TU1) in both March (76.3 percent) and July (61.9 percent; table 10). Other sites had substantially less biovolume contributed by motile taxa than site TU1, with values ranging from 2.6 to 44.9 percent (table 10). Generally, the contribution of motile taxa to total biovolume decreased between March and July. This decrease may be because of the reduced frequency of flooding during summer months, although turbidity values were not significantly different between March and July 2007 (Wilcoxon test, $z=0.62$, $\mathrm{p}$-value $=0.53$ ).

Low-nutrient taxa are indicative of relatively low-nutrient conditions in streams. With the exception of Indian Creek at 


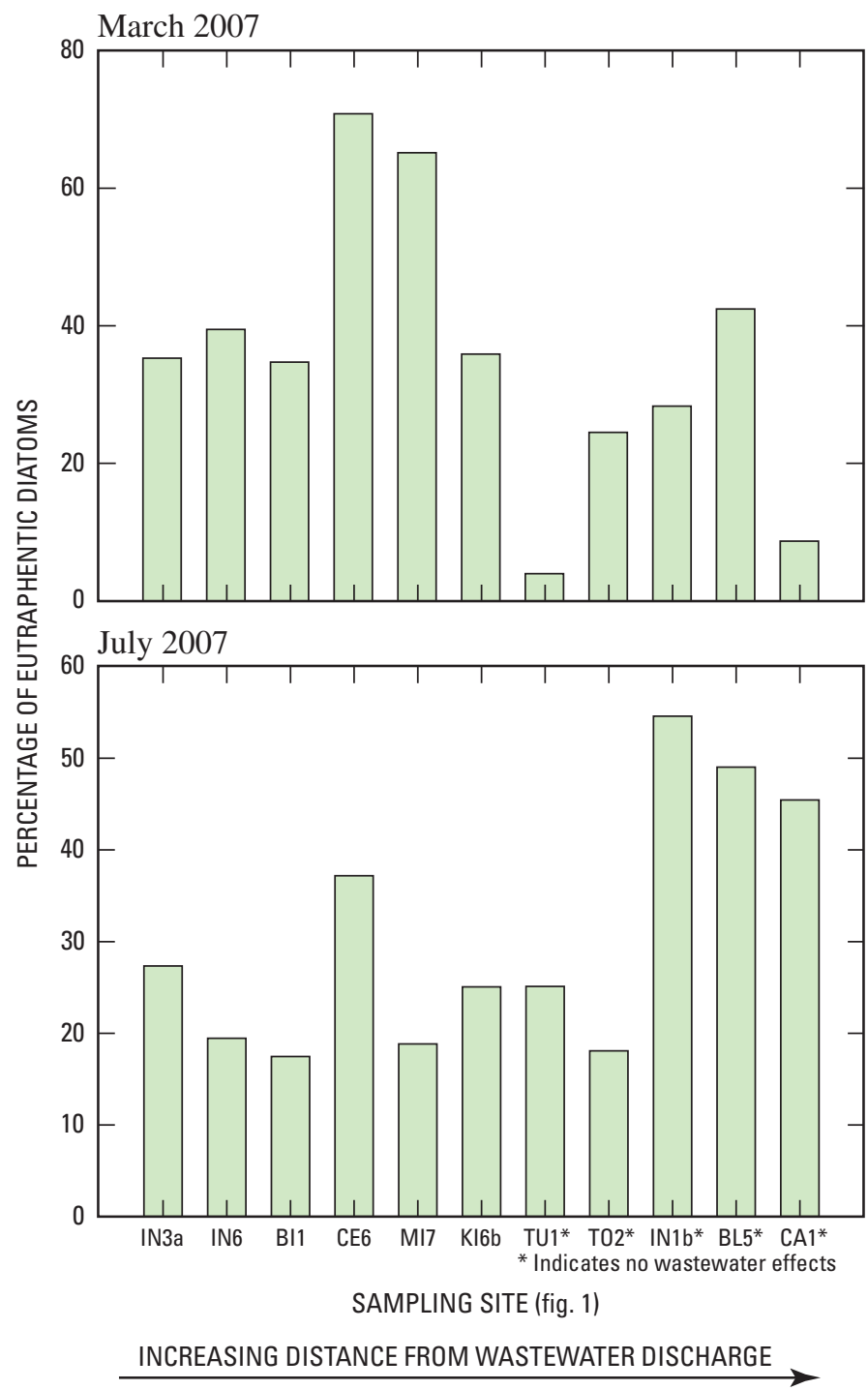

Figure 6. Percentage of algal periphyton biovolume composed of eutraphentic diatoms at biological sampling sites in Johnson County, Kansas (table 1), March and July 2007.

College Boulevard (site IN3a) in March (14.6 percent lownutrient diatoms) and the downstream Kill Creek site (KI6b) in July (34.1 percent low-nutrient diatoms), low-nutrient taxa never comprised more than 9.1 percent of total periphyton biovolume (table 10).

Other community metrics did not show significant differences among sites, and general patterns were similar to those described for other metrics. Selected ADAS metric score are presented in Appendix 5. The lack of distinct trends in metric scores among sites is not uncommon; multivariate statistical approaches often are required to assess algal response along environmental gradients (Lowe and Pan, 1996).

Although periphyton can be used successfully as indicators of biological condition (Bahls, 1993; Rosen, 1995; Lowe and Pan, 1996; Stevenson and Rollins, 2007), periphyton community differences in Johnson County streams were relatively small. Periphyton populations consisted largely of taxa adapted to moderately degraded and nutrient-enriched streams, which indicates that the key factors affecting periphyton community structure were similar among all sites. A range of environmental factors affect periphyton biomass and community composition, including substrate, light availability, and nutrients (Allan, 1995). Despite differences in land use, riffle substrate composition and light availability (canopy cover) generally were similar among sites (tables 1 and 7). Nutrient concentrations were more variable, but differences among sites may not have been large enough to cause substantial shifts in periphyton community composition. In a national assessment, periphyton metrics and nutrient concentrations were able to differentiate between rural and urban watersheds in most ecoregions of the United States. However, this relation did not hold for the Northern Plains ecoregion in which Johnson County is located (Porter and others, 2008). Likewise, Brown (2005) found that there were no consistent changes in periphyton community composition along an urban gradient in the Santa Ana River Basin (California), despite clear patterns in macroinvertebrate and fish communities. Periphyton data collected as part of the study described herein serve as a baseline against which future changes in community composition can be measured, particularly if there are shifts towards nuisance taxa such as filamentous green algae or cyanobacteria.

\section{Macroinvertebrate Communities}

The structure and function of aquatic macroinvertebrate communities have been among the most widely used aquatic indicator components for measuring the effects of anthropogenic (human-related) disturbances on stream and river systems. Their sensitivity, relatively short life cycles, and representativeness as biomonitoring tools make macroinvertebrates well suited as key indicators of changes to natural resources, food-web transfer to higher trophic levels, alteration of system functions, and overall water-resource quality. Community-level responses of the macroinvertebrate component commonly are used for measurement of biological conditions, long-term monitoring, diagnosis of specific environmental problems, measurement of the success of restoration activities, and development of biological criteria in support of water-quality compliance and regulation (Rosenberg and Resh, 1993). As of 1995, nearly one-half of the individual States in the United States, including Kansas, were using macroinvertebrate communities for assessing some aspect of water-resource quality in streams (Southerland and Stribling, 1995). Macroinvertebrate communities also have been used extensively as an indicator of stream quality in urban watersheds (Paul and Meyer, 2001).

\section{Community Composition}

A total of 160 macroinvertebrate taxa were collected at the 20 Johnson County biological sites in 2007 (Appendix 6), 32 of which were non-insect taxa (mostly mollusks, worms, 
Table 10. Percentage contributions of diatom indicator taxa or groups of diatom indicator taxa to total periphyton biovolume at selected biological sampling sites in Johnson County, Kansas, March and July 2007.

[Eutraphentic (high nutrient) taxa, sum of Amphora, Cocconeis, Diatoma, Gyrosigma, Meridion, Nitzchia, and Synedra biovolume; Motile taxa, sum of Gyrosigma, Navicula, Nitzchia, and Sururella biovolume; Low nutrient taxa, sum of Achnanthes, Cymbella, and Encyonema biovolume; *, no wastewater effects; min, minimum; max, maximum]

\begin{tabular}{|c|c|c|c|c|c|c|}
\hline \multirow{2}{*}{$\begin{array}{l}\text { Site } \\
\text { identifier } \\
\text { (fig. 1) }\end{array}$} & & \multicolumn{5}{|c|}{ Percentage contributions to total biovolume } \\
\hline & & $\begin{array}{c}\text { Eutraphentic } \\
\text { (high-nutrient) } \\
\text { taxa }\end{array}$ & Navicula & Nitzchia & Motile taxa & Low-nutrient taxa \\
\hline \multicolumn{7}{|c|}{ March 2007} \\
\hline BI1 & & 34.9 & 3.2 & 6.7 & 31.4 & 0.4 \\
\hline BL5* & & 42.6 & 6.4 & 17.2 & 35.9 & 0 \\
\hline $\mathrm{CA} 1 *$ & & 8.8 & 28.1 & 5.1 & 44.2 & 0 \\
\hline CE6 & & 71.0 & 3.9 & 3.4 & 12.9 & 0 \\
\hline IN1b* & & 28.5 & 1.1 & 22.4 & 44.9 & 0 \\
\hline IN3a & & 35.4 & 10.4 & 13.1 & 35.5 & 14.6 \\
\hline IN6 & & 39.6 & 22.9 & 28.2 & 28.4 & .4 \\
\hline KI6b & & 36.0 & 12.1 & 9.5 & 32.4 & .3 \\
\hline MI7 & & 65.3 & 1.4 & 4.2 & 15.2 & 0 \\
\hline TO2* & & 24.7 & .5 & 1.5 & 4.1 & 0 \\
\hline TU1* & & 4.1 & 1.4 & 4.1 & 76.3 & .1 \\
\hline & $\min$ & 4.1 & .5 & 1.5 & 4.1 & 0 \\
\hline & $\max$ & 71.0 & 28.1 & 28.2 & 76.3 & 14.6 \\
\hline & mean & 35.5 & 8.3 & 10.5 & 32.8 & 1.4 \\
\hline \multicolumn{7}{|c|}{ July 2007} \\
\hline BI1 & & 17.5 & 28.0 & 15.1 & 28.0 & .3 \\
\hline BL5* & & 49.1 & 15.3 & 1.3 & 17.3 & 1.0 \\
\hline CA1* & & 45.5 & 20.5 & 2.7 & 22.1 & .1 \\
\hline CE6 & & 37.2 & 35.8 & 13.2 & 36.6 & 9.1 \\
\hline IN1b* & & 54.7 & 18.7 & 4.6 & 18.7 & 1.1 \\
\hline IN3a & & 27.4 & 26.7 & 8.7 & 26.7 & 6.2 \\
\hline IN6 & & 19.5 & 2.6 & 2.2 & 2.6 & .4 \\
\hline KI6b & & 25.1 & 18.8 & 10.1 & 22.9 & 34.1 \\
\hline MI7 & & 18.9 & 29.8 & 5.8 & 30.7 & .3 \\
\hline TO2* & & 18.2 & 18.2 & 4.3 & 26.7 & .7 \\
\hline \multirow[t]{4}{*}{ TU1* } & & 25.2 & 61.9 & 22.7 & 61.9 & 0 \\
\hline & $\min$ & 17.5 & 2.6 & 1.3 & 2.6 & 0 \\
\hline & $\max$ & 54.7 & 61.9 & 22.7 & 61.9 & 34.1 \\
\hline & mean & 30.8 & 25.1 & 8.2 & 26.8 & 4.8 \\
\hline
\end{tabular}

leaches, and crustaceans). A total of 124 of these taxa also were collected during the 2003 and 2004 sampling as reported by Poulton and others (2007), which represents a 78-percent overlap. Several of the rural sites in Johnson County, including the Captain Creek reference site (CA1), both Kill Creek sites (KI5b, KI6b), the Blue River sites (BL3, BL5), and both Cedar Creek sites (CE1, CE6), each contained more than 40 total taxa in 2007. Among the 128 insect taxa, 32 of these were among the three dominant orders of insects that normally are associated with healthy stream communities (Ephemeroptera, mayflies; Plecoptera, stoneflies; and Trichoptera, caddisflies). There were also 38 midge (Diptera: Chironomidae) taxa, and 8 non-midge Diptera taxa. In addition to EPT taxa, rural sampling sites generally contained a wide diversity of other aquatic macroinvertebrates, including dragonflies and damselflies (Odonata), and riffle beetles (Coleoptera: Elmidae). In contrast, some urban sites had none or very few (less than five) EPT taxa and were dominated by pollution-tolerant organisms such as leeches [Hirudinea: Mooreobdella microstoma (Moore)], planarians (Platyhelminthes: Turbellaria), Oligochaeta worms (Annelida: Oligochaeta, families Naididae and Tubificidae), and midges in the Cricotopus and Orthocladius (Diptera: Chironomidae) groups (Appendix 7). The urban sites included the two Indian Creek sites downstream from WWTF discharge sites (IN3a, IN6). The four most common taxa at all sites except Captain Creek (site CA1) and downstream Blue River (site BL5) were moderately tolerant or tolerant organisms (Appendix 7). 


\section{Macroinvertebrate Metrics}

Values for 11 metrics resulting from the macroinvertebrate sampling are presented in table 11. Metric results are summarized in this section, with the KDHE aquatic-life status metrics described first and the others presented in the order they are listed in table 3.

\section{Macroinvertebrate Biotic Index (MBI)}

MBI is used to evaluate the effects of oxygen-demanding nutrients and organic enrichment on macroinvertebrate populations. It is a family-level biotic index that uses tolerance values ranging from 1 to 11 for insect and mollusk taxa, with smaller values corresponding to less tolerance and a lesser degree of stream degradation (Davenport and Kelly, 1983). MBI values in 2007 ranged from 4.91 at Big Bull Creek (site BI1) to 7.63 at one of the Little Mill Creek sites (LM1c, table 11). Most sampling sites had values between 5.00 and 7.50 (table 11, at the back of this report). Two of the headwater Little Mill Creek sites (LM1a and LM1c) had the largest values (greater than 7.0), and most of the urban sites had values greater than 5.7. None of the sites met KDHE criteria for full support of aquatic life for MBI (less than 4.51, table 12), and most of the urban sites were nonsupporting (greater than 5.39). The smallest MBI values were found at Big Bull Creek (site BI1), the Captain Creek reference site (site CA1), the two upper Blue River sites (BL3, BL5), the upstream Cedar Creek site (CE1), and the upstream Kill Creek sites (KI5, KI6b). MBI values for sites in the Mill Creek watershed ranged from 5.17 to 7.63. The Mill Creek TMDL for biological impairment establishes a MBI goal of 4.5 or less as an average for 200615 (Kansas Department of Health and Environment, 2006).

\section{Kansas Biotic Index (KBI-NO)}

KBI-NO was specifically developed for Kansas and uses aquatic organism tolerances to nutrients and oxygendemanding substances (Huggins and Moffett, 1988). It is a genus-level biotic index calculated in a similar manner as the MBI with a scoring range of 0 to 5 . Small values indicate less tolerance and minimal biological degradation. KBI-NO values in 2007 ranged from 2.20 (Captain Creek, site CA1) to 3.47 (Turkey Creek, site TU1) (table 11). The Captain Creek reference stream (site CA1) and Camp Branch (site BL4) were the only two sites that were fully supporting for this metric (less than 2.61 table 12). With the exception of three Mill Creek sites (MI4, LM1b, and LM1c), all of the urban sites were in KDHE's non-supporting category (greater than 2.99).

\section{EPT Taxa Richness (EPTRich)}

EPT taxa richness is the sum of the number of species belonging to the orders Ephemeroptera (mayflies), Plecoptera (stoneflies), and Trichoptera (caddisflies). Most species belonging to each of these orders are considered to be intolerant of stressors and generally larger numbers of these species indicate higher water quality (Barbour and others, 1999). EPTRich values in 2007 ranged from 0 to 18 and more than one-half (11) of the sampling sites had at least 20 EPT species (table 11). All of the urban sites had EPT richness values less than 5, and two of the sites in the Little Mill Creek watershed had no EPT individuals (sites LM1a, LM1b). Only one site, Camp Branch (site BL4), met KDHE's full-support criteria for this metric (greater than 12 taxa; tables 11 and 12). Moderately tolerant EPT taxa (MBI tolerance values of 3.5 to 5.5 and KBI-NO tolerance values of 2 to 3 ) generally were more abundant than intolerant taxa (MBI tolerance values of 3 or less and KBI-NO values less than 2).

\section{Percentage of EPT (\%EPT)}

The percentage of EPT (abundance) metric is the number of organisms belonging to the orders Ephemeroptera (mayflies), Plecoptera (stoneflies), and Trichoptera (caddisflies) expressed as a percentage of the total number of organisms. It provides information about relative abundance of the three intolerant orders of aquatic insects so large populations of a few species can result in large values. Values in 2007 ranged from a high of 41.6 percent (table 11) at the State reference stream (site CA1) to zero at two sites in the upstream Little Mill Creek watershed (sites LM1a, LM1b). The rural sites all had EPT abundances of more than 25 percent. A total of 13 sites were in the nonsupporting status category for this metric (less than 31 percent, table 12), and 7 of the 11 urban sites had EPT abundances less than 10 percent. No sites sampled in 2007 were in KDHE's fully supporting category for this metric (greater than 48 percent, table 12).

\section{Total Taxa Richness (TRich)}

Total taxa richness represents the number of distinct taxa within a sample. The presence of relatively large numbers of distinct taxa indicates that the habitats and food sources

Table 12. Criteria for four macroinvertebrate metrics used in Kansas to evaluate aquatic-life-support status of streams (Kansas Department of Health and Environment, 2008).

[MBI, Macroinvertebrate Biotic Index; KBI-NO, Kansas Biotic Index; EPTRich, EPT (Ephemeroptera-Plecoptera-Trichoptera) species richness; \%EPT, percentage of EPT species; <, less than; >, greater than]

\begin{tabular}{lcccccc}
\hline \multicolumn{1}{c}{ Aquatic-life support } & Score & MBI & KBI-NO & EPTRich & \%EPT & Mean \\
\hline Fully supporting & 3 & $<4.51$ & $<2.61$ & $>12$ & $>48$ & $>2.49$ \\
Partially supporting & 2 & $4.51-5.39$ & $2.61-2.99$ & $8-12$ & $31-47$ & $1.5-2.49$ \\
Nonsupporting & 1 & $>5.39$ & $>2.99$ & $<8$ & $<31$ & $1.0-1.49$ \\
\hline
\end{tabular}


present at a site can support many species (Barbour and others, 1999). Values for this metric in 2007 ranged from 16 taxa at the unnamed tributary of Little Mill Creek (site LM1b) to 58 taxa at the most upstream Blue River site (BL3). All of the urban sites had less than 35 macroinvertebrate taxa (table 11) which indicates a general pattern of less diversity at urban sites.

\section{Percentage of Scrapers (\%Sc)}

Measures of functional groups associated with specific feeding strategies, such as those taxa that remove periphyton from surfaces by scraping, provide information on community balance (Barbour and others, 1999). Percentage scraper values in 2007 ranged from zero at one of the Little Mill Creek sites (LM1c) to 31.1 percent at one of the upstream Blue River sites (BL5). Values for this metric were generally smaller at the urban sites, and with the exception of the downstream Mill Creek site (MI7), urban sites had percentage scrapers values less than 15 percent (table 11).

\section{Percentage of Oligochaeta (\%Olig)}

Many of the members of this macroinvertebrate group are considered pollution tolerant. Oligochaeta were not identified below the family level in this study. Values in 2007 for this metric ranged from zero at the Big Bull Creek site BI1 to 45.6 percent at the Little Mill Creek site LM1c. Three urban sites had values greater than 10 percent, including two of the Little Mill Creek sites (LM1a and LM1c) and the Turkey Creek site (TU1). All of the rural sites in Johnson County except Kill Creek site KI5b had values less than 5 percent for this metric (table 11).

\section{Percentage of Tanytarsini (\%Tany)}

Tanytarsini, an intolerant tribe of midges (Diptera: Chironomidae), made up less than 2 percent of the organisms at all of the sites in 2007. A total of 11 sites (55 percent) had no Tanytarsini midges, and 8 of these were urban sites (table 11).

\section{Percentage of Intolerant Organisms, KBI-NO<3 (\%Int-KBI)}

This metric represents the relative abundance of organisms that have KBI-NO tolerance values less than 3.0. Percentage of intolerant organisms normally is calculated using tolerance values given in Hilsenhoff (1987) or Lenat (1988). However, for this study, KBI-NO tolerance values were used instead because of their regional specificity for Kansas (Huggins and Moffett, 1988). Values in 2007 ranged from a low of 2.6 percent at one of the Little Mill Creek sites (LM1a) to a high of 50.7 percent at the State reference site on Captain Creek (site CA1). In general, most of the urban sites had smaller \%Int-KBI values (table 11), six of which were less than 10 percent.

\section{Percentage of Ephemeroptera and Plecoptera (\%EP)}

This metric represents a modification of the \%EPT metric and omits the Trichoptera to account for the effect of larger relative abundances of tolerant net-spinning caddisflies often encountered in macroinvertebrate samples from larger urban streams (Poulton and others, 2007). For this reason, the \%EP metric was included in the calculation of multimetric site scores instead of the \%EPT metric. In 2007, the sampling site at Camp Branch (site BL4) and the State reference site at Captain Creek (site CA1) had the largest values for this metric (table 11). With the exception of the lower Mill Creek site (MI7), all of the urban sites had \%EP values less than 3 percent. A total of six urban sites had no organisms in these two insect orders, including Turkey Creek (site TU1), one Indian Creek site (IN3a), the one Mill Creek site (MI4), and all three sites in the Little Mill Creek watershed (sites LM1a, LM1b, LM1c).

\section{Shannon Diversity Index (SDI)}

The Shannon Diversity Index is a core metric that measures community diversity. Larger values indicate more diversity and evenness of species. Values in 2007 ranged from 2.2 at one of the Little Mill Creek sites (LM1c) to 3.6 at Camp Branch (BL4). All of the urban sites had values less than 3.0 for this metric.

\section{Multimetric Scores}

Multimetric scores were developed as an indicator of the relative biological quality of Johnson County streams. In general, less disturbed streams (indicated by larger 10-metric scores) are located in rural areas of the county (fig. 7), including the Captain, Cedar, and Kill Creek, and upstream Blue River watersheds. Sites located in urban areas (11 of the 20 sites sampled in 2007), including four sites that receive wastewater discharges, scored less than rural sites (fig. 7). Each of the three rural sites sampled in 2007 that receive wastewater discharges scored more than urban sites, including those with no wastewater discharge. Wastewater discharges at the rural and urban sampling sites differ in volume and treatment which make direct comparisons difficult. However, data may indicate that, although both wastewater discharge and general urban land use affect macroinvertebrate communities, wastewater alone generally results in less disturbance than the overall effects of urban land use. This is consistent with results reported during 2003 and 2004 by Poulton and others (2007) except that the 10-metric score for one rural site that scored similar to urban sites in 2003 and 2004 (site BI1) increased in 2007 possibly because of changes in upstream wastewater discharges. The two most upstream sites on the Blue River (sites BL3, BL4) scored highest in 2007, better than the reference site on Captain Creek (site CA1). The 10-metric score for the Big Bull Creek site (BI1) which was the lowest scoring rural site in 2003 and 2004 increased to the sixth largest score in 2007. Stream biological quality as indicated by the 10 -metric 


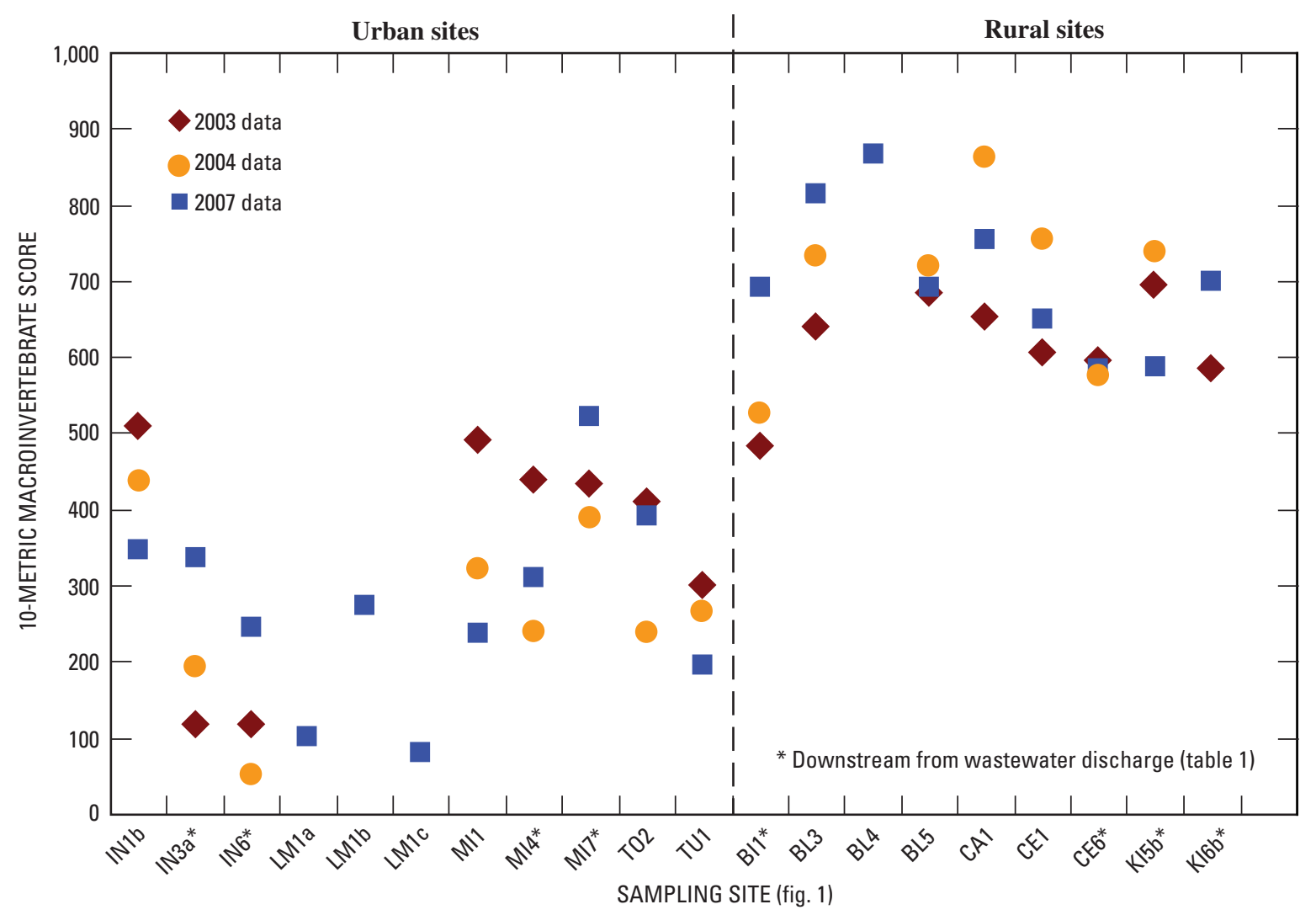

Figure 7. Ten-metric macroinvertebrate scores for biological sampling sites in Johnson County, Kansas (table 1), 2003, 2004, and 2007.

scores declined between 2003 and 2007 at the upstream and middle Mill Creek sites (MI1, MI4). In 2007, two of the three Little Mill Creek headwater sampling sites (LM1a, LM1c) had the smallest 10-metric scores. The downstream Cedar Creek site (CE6) and Blue River site (BL5) sites showed minimal variability between years (fig. 7).

Three categories of biological disturbance (least affected, moderately affected, most affected) were determined by dividing the sampling sites according to the mean of the 10-metric macroinvertebrate scores from 2003 and 2004 (Poulton and others, 2007). The same score ranges were used to categorize sites on the basis of 2007 scores (fig. 8). Ten of the sixteen sites that were sampled all 3 years remained in the same category. One site improved in 2007 compared to 2003 and 2004 (site BI1), which may be related to a reduction in upstream wastewater discharges. Scores at three urban sites decreased from 2003 to 2007 (sites MI1, MI4, IN1b). These patterns indicate that characteristics related to urban land use may be contributing to a decline in the biological conditions in Johnson County streams. This response has been documented in urban streams located in other regions of the United States (Cuffney and others, 2005; Tate and others, 2005). Although cumulative effects of water and streambed-sediment chemicals would be expected to affect benthic communities, biological quality as indicated by the 10-metric scores was not affected substantially by larger metal concentrations in streambed sediment at the upstream Cedar Creek site (CE1).

\section{Aquatic-Life-Support Status}

Aquatic-life-support categories are used as an indication of the ability of a stream to support an acceptable level of aquatic life. The ranges used for scoring the four metrics (MBI, KBI-NO, EPTRich, and \%EPT) are based on the statewide KDHE database for all streams in Kansas (Kansas Department of Health and Environment, 2008) and are shown in table 12. Aquatic-life-support status for each site was determined using the mean of the four KDHE metrics.

In 2007, 60 percent of the 20 biological sampling sites (12 sites) were nonsupporting, and 35 percent ( 7 sites) were partially supporting. Only one site sampled in 2007, Camp Branch (site BL4), attained an aquatic-life status of fully supporting. This site was fully supporting for both the KBINO metric and the EPTRich metric (table 11, fig. 9). No sites attained this status in either 2003 or 2004 (Poulton and others, 2007). With the exception of the downstream Cedar Creek site (CE6), all other rural sites in Johnson County were partially supporting in 2007, including the State reference stream Captain Creek (site CA1). The Captain Creek site in 2007 was the only site besides Camp Branch (site BL4) that attained a fully supporting status for at least one of the four KDHE metrics, which was the KBI-NO metric (2.20, table 11). All of the urban sites were in the nonsupporting category on the basis of 2007 data. In general, this trend is consistent with 2003 and 2004 data for most of the 16 Johnson County 


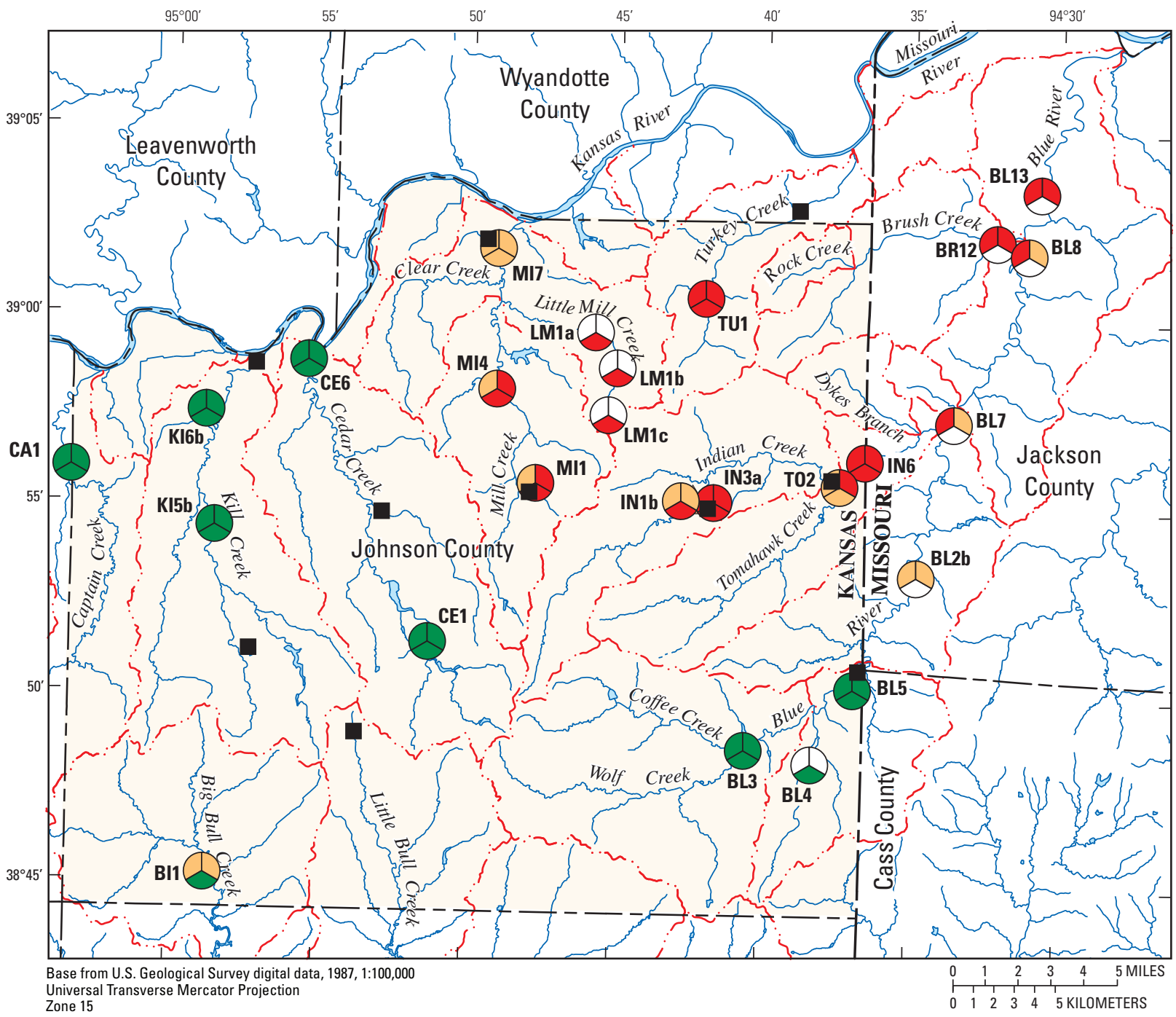

Horizontal coordinate information is referenced to the North American Datum of 1983 (NAD 83)

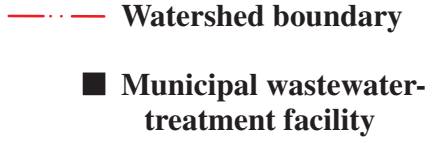

\section{EXPLANATION}

Biological sampling site, identifier, relative biological effects from human disturbance, and year data was collected

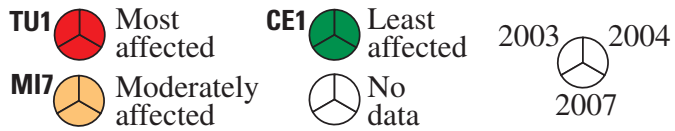

Figure 8. Relative biological effects from human disturbance as indicated by 10-metric macroinvertebrate scores for biological sampling sites in Johnson County, Kansas, 2003, 2004, and 2007 (data for 2003 and 2004 from Poulton and others, 2007).

sites that can be compared across years, with a few exceptions. Both of the upstream Mill Creek sites (MI1, MI4) were partially supporting in 2003 but were non-supporting in both 2004 and 2007. Sampling sites at Big Bull Creek (site BI1), the upstream Blue River site at Stanley, Kansas (site BL3), and the downstream Kill Creek (site KI6b) all attained an aquatic life status of partially supporting on the basis of 2007 data but were nonsupporting in one or both of the earlier sampling years of 2003 and 2004 (Poulton and others, 2007). A total of seven sites, all urban, were nonsupporting for all four of the individual metrics in 2007 and had a mean KDHE metric score of 1.0 (table 11, fig. 9). These included all three Indian Creek sites (IN1b, IN3a, IN6), one site each in the Mill and Little Mill Creek watersheds (sites MI1, LM1a), and sites on Turkey (site TU1), and Tomahawk Creeks (site TO1) (table 11, fig. 9). Many rural sites with large numbers of EPT taxa attained only 


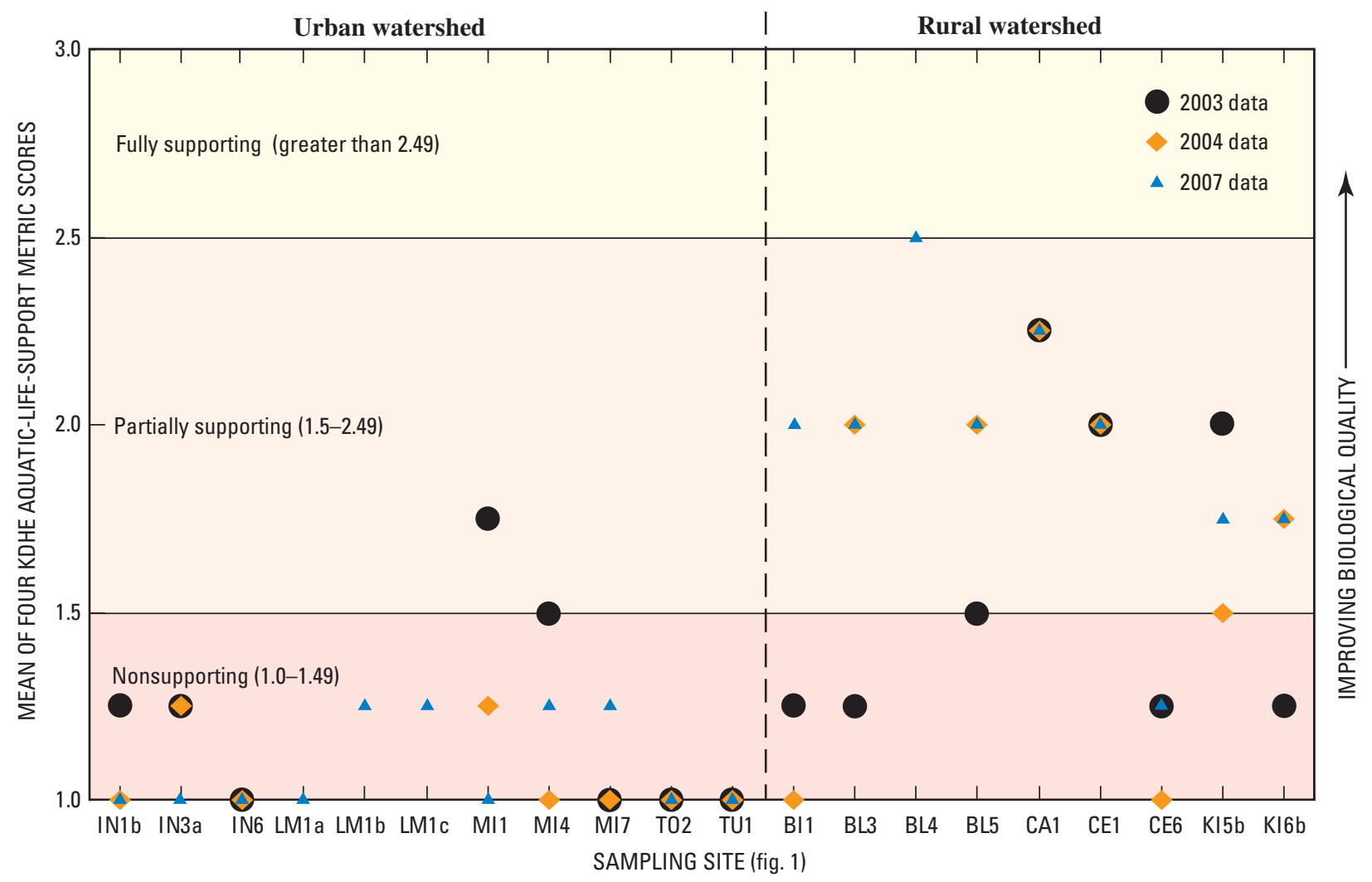

Figure 9. Kansas Department of Health and Environment (KDHE) aquatic-life-support status for biological sampling sites in Johnson County, Kansas (table 1), 2003, 2004, and 2007.

a partially-supporting status because moderately tolerant EPT taxa were more common than intolerant EPT taxa.

Although only one Johnson County sampling site was fully supporting in 2007 , other macroinvertebrate metrics indicate that aquatic communities at some of the rural sites that were classified as partially supporting also supported organisms generally associated with good stream quality. The upstream Blue River sites (BL3, BL5), the Kill Creek sites (KI5b, KI6b), the Cedar Creek sites (CE1, CE6), and Big Bull Creek site (BI1) had among the largest percentages of EPT organisms, among the largest total taxa richness (TRich), and among the largest Shannon Diversity Index (SDI) values. Even though TRich and SDI are not part of the KDHE aquatic-lifesupport assessment framework, they are commonly included in stream assessments in other States including Missouri (Missouri Department of Natural Resources, 2001).

The Kansas aquatic-life-support assessment framework incorporates four metrics (or five metrics if mussels are present) and applies the same support thresholds for aquatic-life attainment to all flowing waters in the state. Additional macroinvertebrate indicator metrics can be valuable for evaluating stream quality, especially in cases where ecoregional differences in aquatic communities have been incorporated into stream impairment assessments (Hornig and others, 1995; Omernik, 1995; Missouri Department of Natural Resources, 2001). Aquatic community data for the Flint Hills subregion in central Kansas differs from the Ozark subregion in southeastern Kansas, although both ecoregions are considered to have some of the largest aquatic species diversity in the State (Huggins and Moffett, 1988). However, most of Johnson County is in the same Osage Cuesta ecoregion, except for a small part of the southeast corner of the county, which is in the Wooded Osage Plains ecoregion (Chapman and others, 2001). Some States also use direct comparisons between reference streams and monitoring sites to evaluate the degree of aquatic-life impairment (DeShon, 1995; Southerland and Stribling, 1995). In 2005, KDHE integrated a probabilistic monitoring approach into the State's stream monitoring program that incorporates stream size into the assessment of aquatic-life support. As part of that approach, aquatic-life-support thresholds were adjusted for stream size on the basis of 10-year median streamflows (Kansas Department of Health and Environment, 2008). Although traditional targeted stream monitoring continues to be the basis for identifying stream impairments, developing TMDLs, and certifying NPDES permits, the adjusted threshold approach takes into account the concept that smaller streams would not be expected to support the same number of intolerant organisms as larger streams (Kansas Department of Health and Environment, 2008). 


\section{Relations Between Stream Quality and Environmental Variables}

Linear relations between selected stream quality and environmental variables are shown in figure 10. Different combinations of variables were selected to provide a general representation of linear relations and data scatter-characteristics between biological and environmental variables. Each graph includes urban land use, habitat score, or 10-metric macroinvertebrate scores on the horizontal axis plotted against another variable of interest. Both strong relations (those with an $\mathrm{R}^{2}$, coefficient of determination, larger than 0.70 ) and weak relations (those with an $\mathrm{R}^{2}$ less than 0.40 ) are shown. Linear relations between urban land use and the 10-metric macroinvertebrate score $\left(\mathrm{R}^{2}=0.81\right)$ as well as the Macroinvertebrate Biotic Index $\left(\mathrm{R}^{2}=0.72\right)$ were strong; however, the linear relation between urban land use and a different macroinvertebrate metric, Kansas Biotic Index $\left(\mathrm{R}^{2}=0.32\right)$, was weak. The linear relation for the 10-metric macroinvertebrate score and specific conductance (a measure of dissolved ions in water) was strong $\left(R^{2}=0.79\right)$, which is consistent with the strong relation between urban land use and specific conductance $\left(\mathrm{R}^{2}=0.80\right)$. The linear relations between the 10-metric macroinvertebrate score and suspended sediment $\left(\mathrm{R}^{2}=0.32\right)$, as well as distance downstream from a wastewater treatment facility $\left(\mathrm{R}^{2}=0.30\right)$, both variables thought to affect biological communities, were weak. Total habitat score generally did not have a large range among sites, and linear relations with urban land use as well as the macroinvertebrate metrics were weak.

Nonparametric Spearman's rank correlation coefficients for all combinations of water chemistry, streambed-sediment chemistry, land use, streamflow, habitat, periphyton, and macroinvertebrate variables were computed. Correlation coefficients (rho values) shown in table 13 are statistically significant with $\mathrm{p}$-values less than 0.05 . Highlighted values are statistically significant with p-values less than 0.001 . Although correlations were calculated for many combinations of variables, table 13 was reduced to include only the variables that were most commonly significantly correlated with other variables. For example, percentage of Tanytarsini midges and the periphyton metrics are not included in table 13 because they did not correlate significantly with many variables. Correlations provide an indication of how well the ranges in biological conditions correspond with environmental variables that may affect them.

Considering all of the water and streambed-sediment quality indicators, specific conductance of the water and the sum of PAHs in streambed sediment were most commonly significantly correlated with biological variables (table 13). Specific conductance of water and PAHs in streambed sediment were significantly negatively correlated with biological quality indicated by 10 -metric scores and each of the individual metrics shown in table 13. Both specific conductance and PAHs also were strongly correlated with urban land use. Total nitrogen in water and suspended-sediment concentra- tion each correlated at a 0.05 probability level with at least 6 macroinvertebrate metrics and the 10-metric score.

Urbanization, expressed either as a percentage of urban land use or as a percentage of impervious surface area, was the variable that showed the strongest correlations with multiple stream-quality indicators including water chemistry, streambed-sediment chemistry, and macroinvertebrate metrics. Both urbanization indicators correlated strongly with at least 7 of the 10 macroinvertebrate metrics and the 10-metric score. Significant correlations between urbanization in the watershed and biological metrics have been reported for Johnson County in Kansas and Cass and Jackson Counties in Missouri (Wilkison and others, 2006; Poulton and others, 2007), elsewhere in the United States (Carter and Fend, 2005; Deacon and others, 2005; Kennen and others, 2005) and in other countries such as Australia (Walsh and others, 2001). In this study, the percentage of urban land use also correlated with 6 of the 17 individual habitat variables (not all of the habitat variables are included in table 13) and the total habitat score. This is in contrast with some studies that have shown that integrated habitat scores are poorly correlated with stream quality (Roesner and Bledsoe, 2003). Most stream habitat protocols incorporate measurements at multiple spatial and geomorphic scales, and this scaling difference has been identified as one plausible explanation for poor correlations (Fitzpatrick and others, 2005). In addition, strong correlations between macroinvertebrate indicators and habitat have been reported in cases when habitat evaluations are adapted for a specific region and the stream disturbance of interest (Fend and others, 2005).

Streamflow variables had large correlation values with numerous stream quality and environmental variables, indicating strong relations, but generally were not significant at the smallest probability levels (p-values less than 0.001) likely because only 7 of the 20 sampling sites had streamflow data. Base-flow index (the ratio of the base flow to total flow volume) correlated strongly ( $\mathrm{p}$-value less than 0.001 ) with 4 of the 10 macroinvertebrate metrics evaluated (KBI-NO, EPT richness, percentage of intolerant organisms, and percentage of EP) and the 10-metric score. The minimum 7-day mean streamflow also correlated strongly with three of the metrics (KBI-NO, EPT richness, and percentage of EPT) and less strongly but still significantly with three additional metrics and the multimetric score. The coefficient of variability, a measure of streamflow variability that is calculated by dividing the standard deviation of the daily flow by mean daily flow, was correlated most strongly with EPT richness but also with six additional macroinvertebrate metrics. The ratio of 75 th to 25 th percentile streamflow, a measure of the magnitude and rate of change in streamflow conditions, correlated strongly with the habitat score and the percentage of scrapers metric. Streamflow variables have been identified as one of the most important predictors of biotic responses in urban streams (Clausen and Biggs, 1997; Konrad and Booth, 2005).

The total habitat score correlated at the 0.05 level with all of the macroinvertebrate metrics including the 10-metric score and correlated strongly ( $p$-values less than 0.001 ) with 


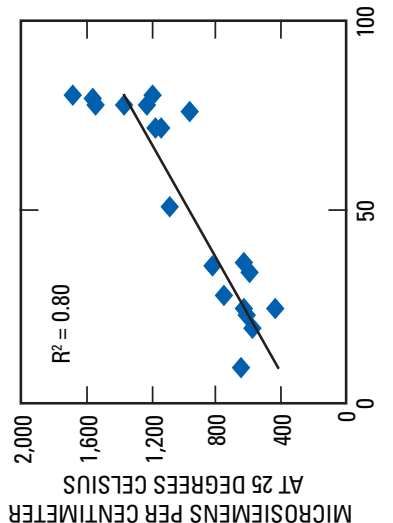

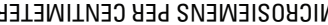

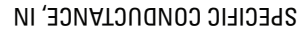

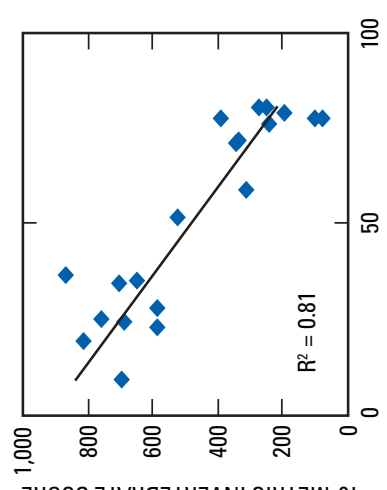

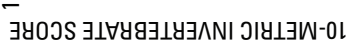

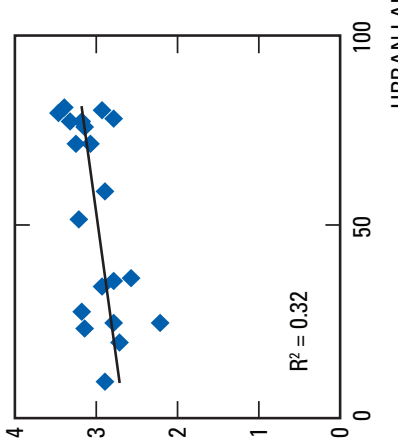

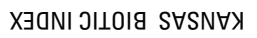

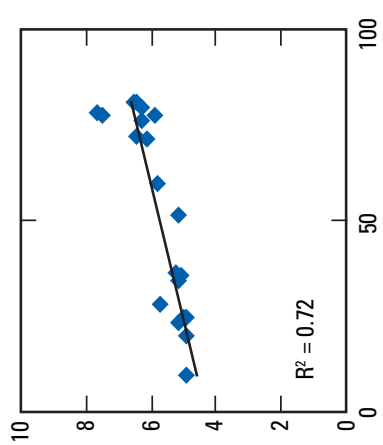

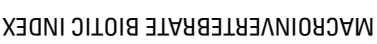
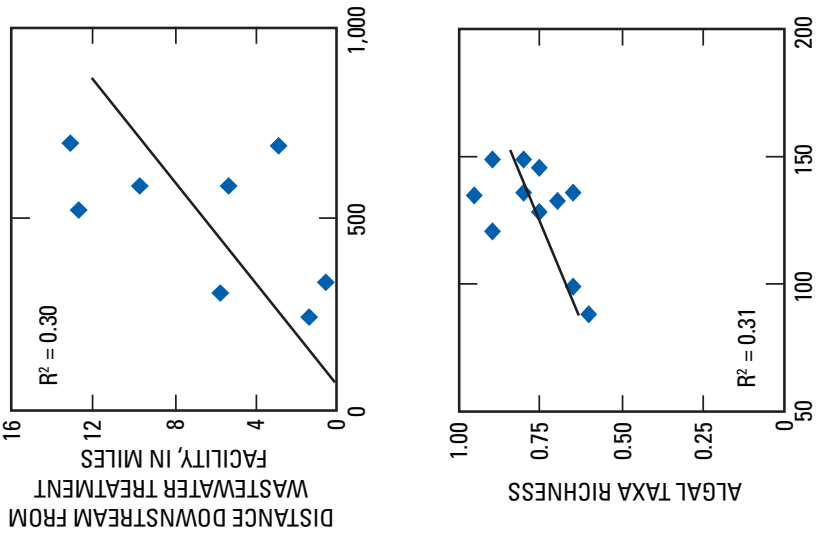

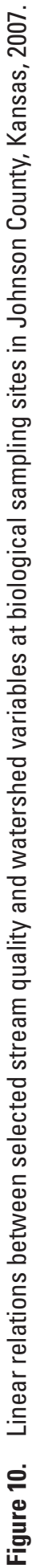


total richness (table 13). The individual habitat variables that most commonly correlated with biological indicators were sinuosity (habitat 1C), buffer length (habitat 2D), and substrate cover diversity (habitat 3E) which were positively correlated, and riffle substrate embeddedness (habitat 3C) and sediment deposition (habitat 3D) which were negatively correlated.

Periphyton measures showed correlations (p-values less than 0.05 ) with a few variables but did not show strong correlations ( $p$-values less than 0.001 ) with any variables and are not shown in table 13. Of the various periphyton indicators, Bahl's pollution tolerance (Bahls, 1993) correlated at the 0.05 probability level with the total habitat score and riffle substrate embeddedness (habitat 3C), sediment deposition (habitat 3D), and substrate cover diversity (habitat 3E).

Most individual macroinvertebrate metrics and the 10-metric scores showed the strongest correlations with land use (percentage of urban and percentage of impervious surface area, table 13). Specific conductance (a measure of dissolved solids) and PAHs in streambed sediment were the only water or sediment chemistry variables that consistently correlated with macroinvertebrate metrics. Overall, macroinvertebrate metrics correlated better with nutrients (particularly nitrogen) in water than in streambed sediment. The 10-metric score correlated significantly with the total habitat score and five individual habitat scores including stream sinuosity (habitat 1C) and buffer length (habitat 2D), riffle substrate embeddedness (habitat 3C), sediment deposition (habitat 3D), and substrate cover diversity (habitat 3E).

After reducing the number of environmental variables (water and streambed chemistry, habitat, land use, and streamflow characteristics) using the results from the Spearman's correlation analysis, PCA analysis was used to determine the primary environmental factors that explain the largest amount of variation among sites. Environmental variables were eliminated if there were few correlations with biological conditions and they were redundant. Some redundancy was retained with variables related to specific conductance (including dissolved solids and major ions) in water to determine which particular variables were most important. Streamflow variables were not used in the analysis because they were only available for 7 of the 20 biological sampling sites and because the analysis will not allow missing data.

The first principal component explained 47 percent of the variance among sites (table 14) and was heavily loaded by dissolved solids in water (including about equal loadings of calcium, chloride, magnesium, and sodium), urbanization (impervious surface area), habitat score, and stream substrate characteristics (embeddedness and cover). The second component explained 16 percent of the variance among sites and was dominated by nutrient concentrations in both water and streambed sediment. The third principal component explained 10 percent of the variance and included nutrients, metals and PAHs in streambed sediment. Therefore, principal components analysis indicated that about 73 percent of the variability among sites can be explained by environmental variables associated with urbanization. Using Primer software's BEST feature (Clarke and Warkwick, 2005), it was determined that specific conductance, impervious surface area, and stream sinuosity explained 85 percent of the variance in macroinvertebrate communities. The BEST feature uses rank correlation to find environmental variables that produce a resemblance matrix similar to the macroinvertebrate resemblance matrix (Clarke and Warwick, 2005).

Nonparametric multidimensional scaling (MDS) is an ordination technique used to represent complex biological relations accurately in a small dimensional space (Clarke and Warwick, 2005). MDS graphs show relative likeness among sampling sites, and the axes have no units or scales. MDS graphs of macroinvertebrate abundance data generated using the Primer software showed distinct separation of sites on the basis of rural or urban land use along the first axis (fig. 11A). One exception was that macroinvertebrate indicators at the downstream urban Mill Creek site (MI7) were more similar to communities in rural streams. The rural sites tended to group in a small cluster except for Captain Creek (site CA1) and to a lesser extent Camp Branch (site BL4), the two sites that ranked highest in the 10-metric scores (fig. 11A). Sites within the same watershed generally clustered together (fig. 11A). The Indian Creek sites were tightly clustered, whereas the Mill Creek sites were widely spread, which indicates that macroinvertebrate communities within the same watershed were less similar to each other in the Mill Creek watershed. Periphyton abundance data for March 2007 showed less grouping by land use than was evident with macroinvertebrate data (fig. 11B). Indian Creek at College Boulevard (site IN3a) is separated from the others possibly because the two dominant taxa that occurred in March at that site, accounting for 29 percent of the total taxa, were not found at any other site. In addition, the rural Captain Creek site (CA1) and urban Turkey Creek site (TU1) are somewhat separated from the central cluster (fig. $11 B)$.

\section{Biological Responses to Environmental Variables}

In many parts of the United States, land-use change within watersheds and corresponding stream disturbances are associated with the conversion of rural agricultural land use to urban land use (Paul and Meyer, 2001). These changes can be accentuated when connected rural areas and undeveloped buffers become fragmented and more interspersed (Kennen and others, 2005). Biological effects may begin even at minimal levels of urbanization (Booth and Reinelt, 1993; Booth and Jackson, 1997; Wang and others, 2001), and these responses may occur before stream habitats become altered (Walters and others, 2005). Understanding the causes and sources of stress is important in preservation, rehabilitation, and management of streams as they become more urbanized (Cottingham and others, 2004), and it is often the most headwater reaches that are developed last (Limburg and others, 2005). The complexity associated with understanding land use effects 
Table 13. Spearman correlation matrix for water and streambed-sediment chemistry, land use, streamflow, habitat, and macroinvertebrate variables at biological sampling sites in Johnson County, Kansas, 2007.

[Correlation coefficents $\left(\mathrm{R}^{2}\right)$ shown are significat at $\mathrm{p}$-value $<0.05$; yellow highlight indicates values significant at $\mathrm{p}$-value $<0.001$; MBI, Macroinvertebrate Biotic Index; KBI-NO, Kansas Biotic Index; E, Ephemeroptera; P, Plecoptera; T, Trichoptera; PAHs, polycyclic aromatic hydrocarbons; <, less than]

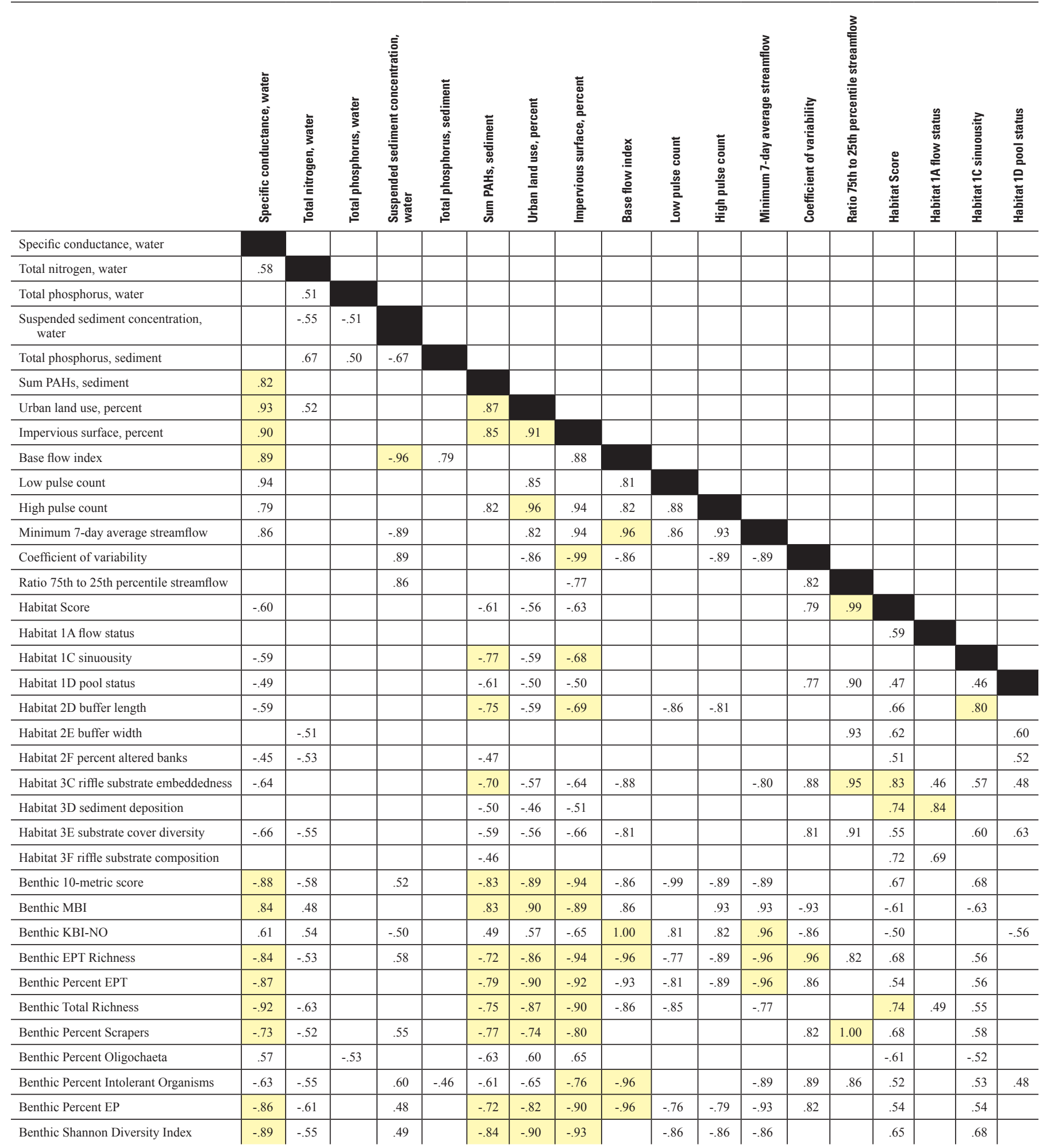


Table 13. Spearman correlation matrix for water and streambed-sediment chemistry, land use, streamflow, habitat, and macroinvertebrate variables at biological sampling sites in Johnson County, Kansas, 2007.-Continued

[Correlation coefficents $\left(\mathrm{R}^{2}\right)$ shown are significat at $\mathrm{p}$-value $<0.05$; yellow highlight indicates values significant at $\mathrm{p}$-value $<0.001$; $\mathrm{MBI}$, Macroinvertebrate Biotic Index; KBI-NO, Kansas Biotic Index; E, Ephemeroptera; P, Plecoptera; T, Trichoptera; PAHs, polycyclic aromatic hydrocarbons; <, less than]

\begin{tabular}{|c|c|c|c|c|c|c|c|c|c|c|c|c|c|c|c|c|c|c|}
\hline & 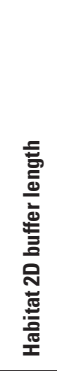 & 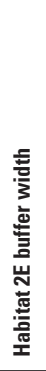 & 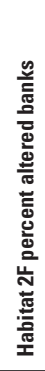 & 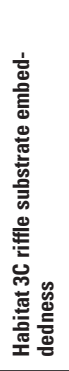 & 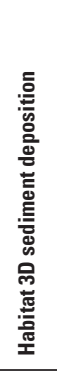 & 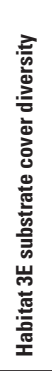 & 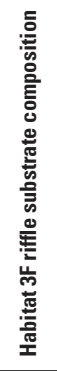 & 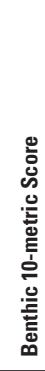 & 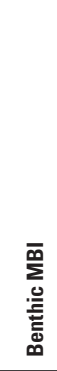 & 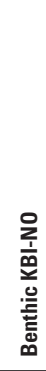 & 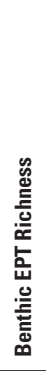 & 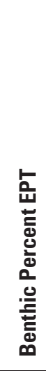 & 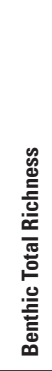 & 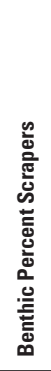 & 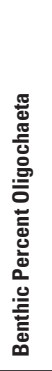 & 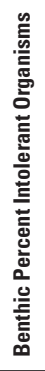 & 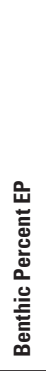 & 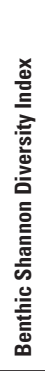 \\
\hline \multicolumn{19}{|l|}{ Specific conductance, water } \\
\hline \multicolumn{19}{|l|}{ Total nitrogen, water } \\
\hline \multicolumn{19}{|l|}{ Total phosphorus, water } \\
\hline \multicolumn{19}{|l|}{$\begin{array}{l}\text { Suspended sediment concentration, } \\
\text { water }\end{array}$} \\
\hline \multicolumn{19}{|l|}{ Urban land use, percent } \\
\hline \multicolumn{19}{|l|}{ Impervious surface, percent } \\
\hline \multicolumn{19}{|l|}{ Base flow index } \\
\hline \multicolumn{19}{|l|}{ Low pulse count } \\
\hline \multicolumn{19}{|l|}{ High pulse count } \\
\hline \multicolumn{19}{|l|}{ Minimum 7-day average streamflow } \\
\hline \multicolumn{19}{|l|}{ Coefficient of variability } \\
\hline \multicolumn{19}{|l|}{ Ratio 75 th to 25 th percentile streamflow } \\
\hline \multicolumn{19}{|l|}{ Habitat Score } \\
\hline \multicolumn{19}{|l|}{ Habitat $1 \mathrm{~A}$ flow status } \\
\hline \multicolumn{19}{|l|}{ Habitat 1C sinuousity } \\
\hline \multicolumn{19}{|l|}{ Habitat $2 \mathrm{E}$ buffer width } \\
\hline Habitat $3 \mathrm{~F}$ riffle substrate composition & & & & .56 & .85 & & & & & & & & & & & & & \\
\hline Benthic 10-metric score & .75 & & & .64 & .49 & .60 & & & & & & & & & & & & \\
\hline Benthic MBI & -.67 & & & -.73 & -.50 & -.63 & & -.88 & & & & & & & & & & \\
\hline Benthic KBI-NO & -.48 & .49 & & -.46 & & -.63 & & -.67 & .59 & & & & & & & & & \\
\hline Benthic EPT Richness & .66 & & & .63 & .54 & .59 & & .93 & -.88 & -.62 & & & & & & & & \\
\hline Benthic Percent EPT & .63 & & & .55 & .50 & .49 & & .92 & -.91 & -.65 & .91 & & & & & & & \\
\hline Benthic Total Richness & .65 & & .45 & .68 & .60 & .65 & .55 & .92 & -.85 & -.56 & 92 & .86 & & & & & & \\
\hline Benthic Percent Scrapers & .58 & & & .74 & .56 & .49 & .50 & .82 & -.78 & & .84 & .75 & .78 & & & & & \\
\hline Benthic Percent Oligochaeta & -.47 & & & -.61 & -.61 & & -.48 & -.66 & .69 & & -.64 & -.68 & -.63 & -.61 & & & & \\
\hline Benthic Percent Intolerant Organisms & .55 & & .46 & .45 & & .61 & & -.82 & -.71 & -.81 & .73 & .72 & .66 & .61 & & & & \\
\hline Benthic Percent EP & .57 & & & .58 & & .61 & & .91 & -.84 & -.64 & .91 & .92 & .89 & .80 & -.65 & -71 & & \\
\hline Benthic Shannon Diversity Index & .75 & & .51 & .63 & .48 & .64 & & .96 & -.85 & -.61 & .89 & .86 & .92 & .77 & -.59 & -73 & .86 & \\
\hline
\end{tabular}


A. Multidimensional scaling by watershed for relative macroinvertebrate abundance

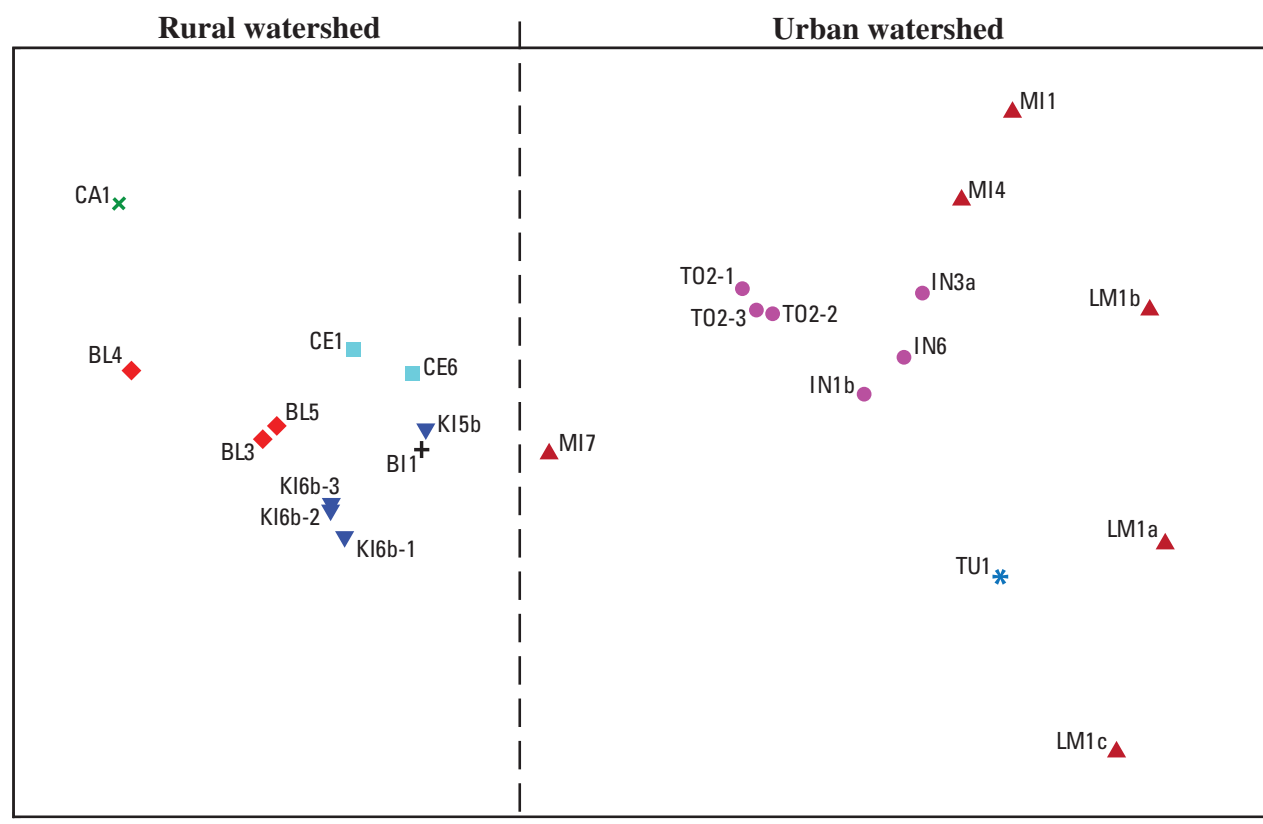

EXPLANATION

Watershed name and site identifier

(fig. 1)

Bl1+ Big Bull Creek

$\mathrm{BL} \downarrow$ Blue River

CA1 $\times$ Captain Creek

CE1 1 Cedar Creek

IN6• Indian Creek

KI5b $\nabla$ Kill Creek

MI7 $\triangle$ Mill Creek

TU1* Turkey Creek

$\frac{\mathscr{N}}{x}$

B. Multidimensional scaling by primary land use for relative periphyton abundance in March

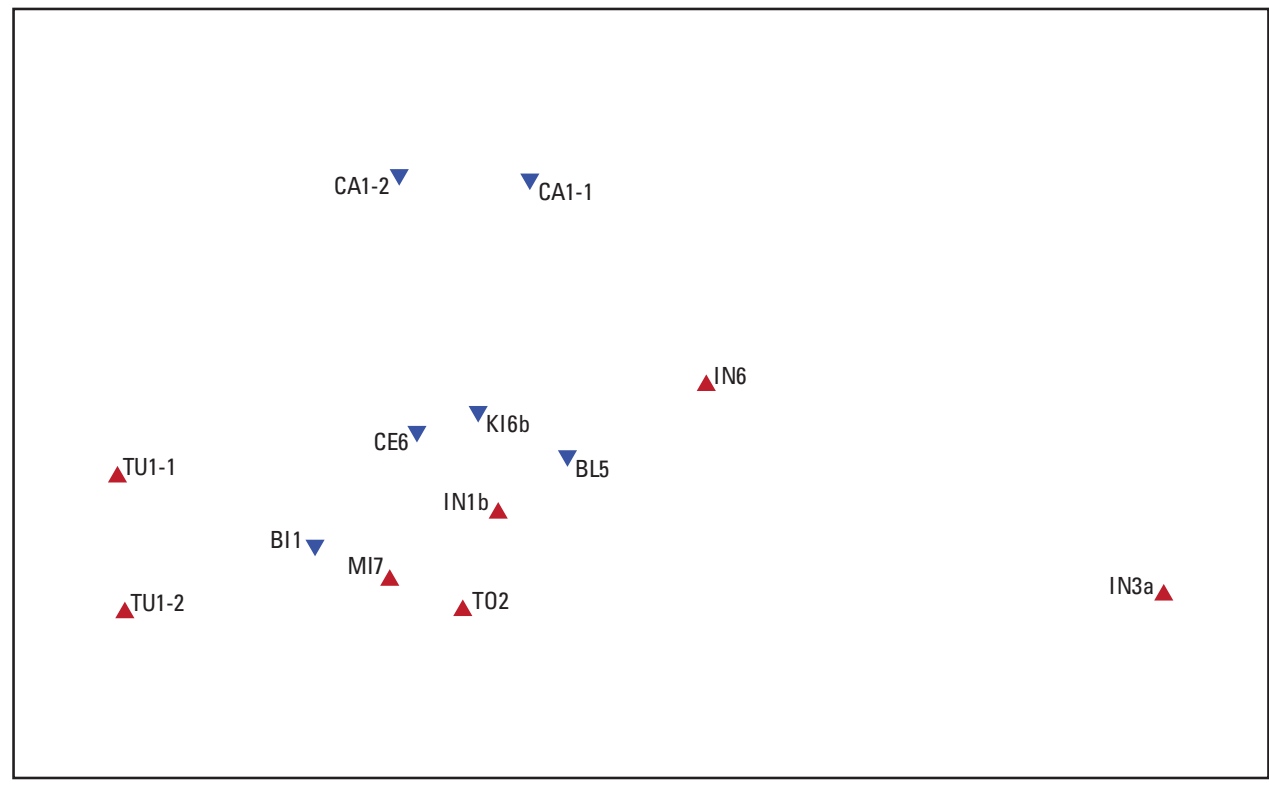

EXPLANATION

Land use and site identifier (fig. 1)

IN6 $\triangle$ Urban site

BL5 $\nabla$ Rural site

AXIS 1

Figure 11. Multidimensional scaling (MDS) of biological communities at 20 biological sampling sites in Johnson County, Kansas, 2007.

on biological communities arises from difficulty integrating information from multiple spatial and geomorphic scales and the challenge of identifying direct cause-and-effect relations between biotic and abiotic factors (Roesner and Bledsoe, 2003; Fitzpatrick and others, 2005). This may explain why periphyton and macroinvertebrate indicators generated smaller correlation coefficients with total habitat scores than with individual habitat metrics. Other effects such as wastewater discharges and urban runoff are present to varying degrees across the study area, and this may be why some urban Johnson County streams with degraded water quality and poor biotic condition may have good overall habitat quality. This phenomenon has been reported in previous research studies of urban streams (Walters and others, 2005).

Results of this study indicate that biological communities in streams of Johnson County respond to a combination of environmental factors. Aquatic organisms in these streams are exposed either directly to altered flow regime and 
Table 14. Results of principal components analysis of stream quality and watershed environmental variables at biological sampling sites in Johnson County, Kansas, 2007.

[Numbers in bold have the largest loadings in each component; PAHs, polycyclic aromatic hydrocarbons.]

\begin{tabular}{|c|c|c|c|}
\hline Variable & $\begin{array}{c}\text { Principal component } 1 \\
\text { (47 percent) }\end{array}$ & $\begin{array}{c}\text { Principal component } 2 \\
\text { (16 percent) }\end{array}$ & $\begin{array}{c}\text { Principal component } 3 \\
\text { (10 percent) }\end{array}$ \\
\hline Specific conductance, water & -0.282 & -0.113 & -0.029 \\
\hline Dissolved solids, water & -.291 & -.082 & -.034 \\
\hline Calcium, water & -.254 & -.192 & .014 \\
\hline Magnesium, water & -.265 & .031 & -.052 \\
\hline Sodium, water & -.295 & -.065 & -.016 \\
\hline Chloride, water & -.287 & -.115 & 0 \\
\hline Suspended-sediment concentration, water & .146 & -.279 & -.174 \\
\hline Total nitrogen, water & -.179 & .300 & .322 \\
\hline Total phosphorus, water & -.055 & .395 & .405 \\
\hline Total nitrogen, bed sediment & .013 & .325 & -.247 \\
\hline Total phosphorus, bed sediment & -.068 & .426 & -.203 \\
\hline Sum nutrients, bed sediment & -.013 & .424 & -.279 \\
\hline Sum metals, bed sediment & -.018 & .233 & -.437 \\
\hline Sum PAHs, bed sediment & -.100 & .160 & .399 \\
\hline Urban land use & -.280 & -.085 & -.001 \\
\hline Impervious surface area & -.285 & -.109 & .016 \\
\hline Habitat score & .208 & -.016 & .045 \\
\hline Stream sinuosity, habitat $1 \mathrm{C}$ & .193 & .064 & .165 \\
\hline Stream buffer length, habitat 2D & .198 & -.013 & .116 \\
\hline Stream-riffle substrate embeddedness, habitat $3 \mathrm{C}$ & .234 & .019 & .009 \\
\hline Stream-sediment deposition, habitat 3D & .144 & .042 & .286 \\
\hline Stream-substrate cover diversity, habitat 3E & .224 & -.077 & -.172 \\
\hline
\end{tabular}

degraded stream quality or indirectly as a result of land-use changes associated with urban development. These results are supported by the conceptual framework outlined for urban streams by Karr and Yoder (2004), which describes the linkages between human actions associated with urbanization, corresponding changes in stream ecosystems, and the biotic responses that result from these changes. Urbanization, expressed as a percentage of urban land use or as a percentage of impervious surface area, was the most important variable for determining the quality of streams in Johnson County. The percentage of urban land use variable integrates many of the human actions associated with urbanization and the resulting changes in flow regime, habitat, water quality, and ecosystem functions (Konrad and Booth, 2005). In addition, specific conductance (a measure of dissolved solids) of stream water and PAHs in streambed sediment were correlated with biological quality of streams. Although cumulative effects of water and streambed-sediment chemicals would be expected to affect benthic communities, biological quality as indicated by the 10-metric scores was not affected substantially by larger metal concentrations in streambed sediment at the upstream
Cedar Creek site (CE1). Some macroinvertebrate characteristics appeared to be responsive to overall as well as individual stream-habitat conditions.

Biological sampling sites that have the smallest MBI scores continued to be the least urban-affected sites, Big Bull Creek (site BI1), the upstream Blue River (sites BL3, BL5), Cedar Creek (site CE1), and Kill Creek (sites KI5b, KI6b), with conditions similar to the Captain Creek reference stream (site CA1). The 2007 macroinvertebrate data indicated on the basis of 10-metric scores that biological quality improved at one rural site (site BI1) and declined at three urban sites (MI1, MI4, IN1b). Biological communities in rural streams may recover more easily from environmental stresses than communities in urban streams that must overcome the cumulative effects of multiple stressors resulting from continued development. All sampling sites except Camp Branch (site BL4) in the Blue River watershed continue to show some level of impairment on the basis of aquatic-life-support status.

The quantification of biological responses to environmental variables is made difficult by the complex stream system and numerous spatial and temporal variables that drive those 
responses. This complexity makes it difficult to determine precisely which environmental variables most affect biological conditions because so many variables are interrelated. Therefore, improvement in any single environmental variable may not result in measurable improvements in stream quality. Just as cumulative effects of urbanization reduce stream quality, it is likely that the cumulative effects of environmental improvements will lead to increasing biological quality. In addition, cause-and-effect relations are difficult to define, particularly when considering cumulative effects. For example, strong correlations exist between specific conductance (dissolved solids) in water and biological indicators such as macroinvertebrate metrics. However, simply reducing dissolved solids in stream water may have no effect on biological communities because specific conductance may be merely a surrogate for urbanization.

Even though studies have indicated that reach-scale features such as stream habitat and bank stability can be manipulated to improve biotic conditions, the most important underlying variables that affect overall stream quality may be those that can be managed at the watershed or land-use scales (Walsh and others, 2005a). Management at these scales could include addition of vegetation filter strips (Booth and others, 2003), design of more appropriate stormwater drainage or retention systems (Walsh and others, 2005b), improved regional urban planning (Limburg and others, 2005), and preservation of lengthy and continuous stream buffers such as those located in the streamway park system in Johnson County. Although biological communities clearly are affected by multiple environmental factors, management practices that focus on those factors that are most important may be an effective approach. Management practices that affect environmental variables and that appear to be most important for Johnson County streams include protection of stream corridors, measures that reduce the effects of impervious surfaces associated with urbanization, reduction of dissolved solids in stream water, reduction of PAHs entering streams and accumulating in streambed sediment, improvement of buffer conditions particularly related to the continuity of buffers and tracts of undeveloped land, and improvement of streambed substrate conditions by reducing streambank erosion and stream-sediment loads. These management approaches directly address many of the major sources of urban-related stress that have been identified as important for preservation of stream quality and for rehabilitation and management of streams in urban areas (Brown and others, 2005; Erickson and others, 2005; Kennen and others, 2005; Konrad and Booth, 2005).

\section{Summary}

Stream quality and relations to environmental variables in Johnson County, northeastern Kansas, were evaluated using water, streambed sediment, land use, streamflow, habitat, algal periphyton (benthic algae), and benthic macroinvertebrate data. Water, streambed sediment, and macroinvertebrate samples were collected in March 2007 during base flow at 20 biological stream sampling sites that represent 11 different watersheds in the county. In addition, algal periphyton samples were collected twice during different seasons at one half of the sites. Environmental data including water and sediment chemistry data (such as nutrients, fecal-indicator bacteria, and organic wastewater compounds), land use, streamflow, and habitat data were used in statistical analyses to evaluate relations between biological conditions and variables that may affect them.

The purpose of this report is to assess the quality of Johnson County streams by characterizing biological (macroinvertebrate and algal periphyton) communities and determining their relation to environmental variables such as water chemistry, streambed-sediment chemistry, land use, streamflow, and habitat conditions. This report includes: (1) evaluation of water and streambed-sediment chemistry, (2) assessment of habitat conditions, (3) comparison of biological community attributes (such as composition, diversity, and abundance among sampling sites), (4) placement of stream sites into KDHE-defined impairment categories, (5) evaluation of biological data relative to environmental variables, and (6) evaluation of changes in biological communities including year-to-year variability and effects of urbanization on stream quality.

Chemicals in water and streambed sediment varied across the study area. Dissolved solids ranged from $282 \mathrm{mg} / \mathrm{L}$ in water from the Captain Creek reference site to $1,000 \mathrm{mg} / \mathrm{L}$ in water from one of the headwater Mill Creek streams. Four sites with urban land use larger than 77.0 percent had the largest concentrations of calcium, sodium, and chloride. Chloride concentration in water from one of the Mill Creek headwater sites was more than 25 times the concentration found in water from the reference stream. The largest nitrogen and phosphorus concentrations occurred downstream from wastewater treatment plants. The upstream Cedar Creek site had the largest concentrations of nearly all trace metals and nutrients measured in streambed sediment, many of which were about double the median concentrations found at other sites. Polycyclic aromatic hydrocarbons (PAHs) in streambed sediment were detected at about one-half of the biological sampling sites, mostly in urban areas, and concentrations for individual PAH compounds generally exceeded probable effects concentrations at most of the sites where they were detected. Probable effects concentrations for total PAHs were not exceeded anywhere sampled.

Total habitat scores (the sum of the 17 scores for individual habitat metrics) ranged from the least optimal score for the Turkey Creek sampling site, one of the most urban sites, to the most optimal scores for the upstream Kill Creek and Blue River sampling sites. Poor bank stability and riparian conditions contributed to low habitat scores at several sites. Streamway parks provided protection of riparian areas at some sites.

The most commonly occurring periphyton taxa in both March and July generally were indicative of somewhat 
degraded, mesoeutrophic conditions with small to moderate amounts of organic enrichment. Cyanobacteria, typically indicative of nutrient and organic enrichment, were present but rare in Johnson County streams. Periphyton abundance and biomass were largest at most sites in March, with the notable exception of Indian Creek at State Line Road (site IN6), which had much larger values than other sites in July. Chlorophyll values reached nuisance threshold levels in Johnson County streams during March, including the stream that was considered to represent reference conditions.

Results of this study indicate that biological quality at nearly all biological sampling sites in Johnson County has some level of impairment. Multimetric macroinvertebrate scores indicate that less disturbed streams are located in the less urban parts of the county, including the Captain, Cedar, and Kill Creek, and upstream Blue River watersheds. The two most upstream sampling sites on the Blue River scored highest using multimetric scores, better than the reference site on Captain Creek. Although cumulative effects of water and streambed-sediment chemicals would be expected to affect benthic communities, biological quality as indicated by the multimetric scores was not affected substantially by larger metal concentrations (exceeding probable effects concentrations for chromium and nickel) in streambed sediment at the upstream Cedar Creek sampling site. In 2007, 60 percent (12) of the sampling sites were nonsupporting, and 35 percent (7 sites) were partially supporting. Only one site sampled in 2007, Camp Branch in the upstream Blue River watershed, attained an aquatic-life status of fully supporting. Since 2003, biological quality improved at one rural sampling site, possibly because of changes in wastewater affecting the site, and declined at three urban sites possibly because of the combined effects of ongoing development. Rural streams in the western and southern parts of the county, with land-use conditions similar to those found at the State reference site (Captain Creek), continue to support some organisms normally associated with healthy streams.

Most individual macroinvertebrate metrics and the multimetric scores showed the strongest correlations with urbanization variables (percentage of urban land use and percentage of impervious surface area). Specific conductance of water and PAHs in streambed sediment were strongly negatively correlated with biological quality indicated by macroinvertebrate metrics. Specific conductance is a measurement of dissolved solids in stream water and is determined primarily by the amount of groundwater contributing to streamflow, the amount of urbanization, and discharges from wastewater and industrial sites. Several different streamflow variables correlated with macroinvertebrate characteristics. Total habitat score, which incorporated 17 individual habitat variables, correlated with each of the macroinvertebrate metrics and the 10-metric score. The individual habitat variables that most commonly were correlated with biological indicators included stream sinuosity, buffer length, and substrate cover diversity which were positively correlated, and riffle substrate embeddedness and sediment deposition which were negatively correlated. Statistical analysis indicated that specific conductance, impervious surface area (a measure of urbanization), and stream sinuosity explained 85 percent of the variance in macroinvertebrate communities.

Biological communities respond to a combination of environmental factors. Urbanization, expressed as a percentage of urban land use or as a percentage of impervious surface area, integrates many human actions that change flow regime, habitat, water quality, and ecosystem functions, and was the most important variable for determining the quality of streams in Johnson County. Dissolved solids in stream water were correlated with biological quality of streams.

Management practices that affect environmental variables and that appear to be most important for Johnson County streams include protection of stream corridors, measures that reduce the effects of impervious surfaces associated with urbanization, reduction of dissolved solids in stream water, reduction of PAHs entering streams and accumulating in streambed sediment, improvement of buffer conditions particularly related to buffer continuity, and improvement of streambed substrate conditions by reducing sediment loads to streams. Because of the complexity of urban stream systems and connectivity of various factors affecting stream quality, improvement in any single environmental variable may not result in measurable improvements in stream quality. Just as cumulative effects of urbanization reduce stream quality, it is likely that the cumulative effects of environmental improvements will lead to improved biological quality.

\section{References Cited}

Allan, J.D., 1995, Stream ecology — structure and function of running waters: Boston, Massachuesetts, Kluwer Academic Publishers, 388 p.

American Public Health Association, American Water Works Association, and Water Environment Federation, 1995, Standard methods for the examination of water and wastewater (19th ed.): Washington, D.C., American Public Health Association, $905 \mathrm{p}$.

Bahls, L.L., 1993, Periphyton bioassessment methods for Montana streams: Water Quality Bureau, Department of Health and Environmental Sciences, 69 p.

Ball, J., 1982, Stream classification guidelines for Wisconsin: Wisconsin Department of Natural Resources Technical Bulletin, Wisconsin Department of Natural Resources, Madison, Wisconsin. 
Barbour, M.T., Diamond, J.M., and Yoder, C.O., 1996, Biological assessment strategies: Applications and Limitations, in Grothe, D.R., Dickson, K.L., and Reed-Judkins, D.K., eds., Whole effluent toxicity testing - an evaluation of methods and prediction of receiving system impacts: SETAC Press, Pensacola, Florida, p. 245-270.

Barbour, M.T., Gerritsen, J., Snyder, B.D., and Stribling, J.B., 1999, Rapid bioassessment protocols for use in streams and wadeable rivers - periphyton, benthic macroinvertebrates, and fish ( $2 \mathrm{~d}$ ed.): U.S. Environmental Protection Agency Report, EPA 841/B-99/002, 18 p.

Barbour, M.T., and Stribling, J.B., 1991, Use of habitat assessment in evaluating the biological integrity of stream communities, in Gibson, George, ed., Biological criteria-research and regulation, Proceedings of a Symposium, 12-13 December 1990, Arlington, Virginia: Washington, D.C., Office of Water, U.S. Environmental Protection Agency, EPA-440-5-91-005, p. 25-38.

Barbour, M.T., and Stribling, J.B., 1994, A technique for assessing stream habitat structure, in Conference proceedings, Riparian ecosystems in the humid U.S - functions, values and management: March 15-18, 1993, Atlanta, Georgia, Washington, D.C., National Association of Conservation Districts, p. 156-178.

Barbour, M.T., Stribling, J.B., and Karr, J.R., 1995, Multimetric approach for establishing biocriteria and measuring biological condition, in Davis, W.S., and Simon, T.P., eds., Biological assessment and criteria - tools for water resource planning and decision making: Boca Raton, Florida, Lewis Publication, chap. 6, p. 63-77.

Blevins, D.W., 1986, Quality of stormwater runoff in the Blue River basin, Missouri and Kansas, July-October 1981 and April-July 1982: U.S. Geological Survey Water-Resources Investigations Report 84-4226, $131 \mathrm{p}$.

Blomqvist, P., and Herlitz, E., 1998, Methods for quantitative assessment of phytoplankton in freshwaters, part 2: Naturvardsverket, Stockholm, Report 4861, 70 p.

Booth, D.B., and Jackson, C.R., 1997, Urbanization of aquatic systems - impacts, solutions, and prognoses: Northwest Environmental Journal, v. 7, p. 93-118.

Booth, D.B., Karr, J.R., Schauman, S., Konrad, C.P., Morley, S.A., Larson, M.G., and Burges, S.J., 2003, Management strategies for urban stream rehabilitation, in Proceedings, National Conference on Urban Storm Water-Enhancing Programs at the Local Level, February17-20, 2003, Chicago, Illinois: U.S. Envriomental Protection Agency, EPA/626/R-03/003, p. 20-28, available on Web, accessed August, 2008, at http://www.epa.gov/ORD/NRMRL/ pubs/625r03003/02Booth.pdf
Booth, D.B., and Reinelt, L., 1993, Consequences of urbanization on aquatic systems - measured effects, degradation thresholds, and corrective strategies, in Proceedings watershed '93, a national conference on watershed management, March 21-24, 1993, Alexandria, Virginia: U.S. Environmental Protection Agency, p. 545-550.

Brower, J.E., Zar, J.H., and vonEnde, C.N., 1990, Field and laboratory methods for general ecology (3rd ed.): Dubuque, Iowa, Wm. C. Brown Publishers, 237 p.

Brown, L.R., 2005, Aquatic assemblages of the highly urbanized Santa Ana River Basin, California: American Fisheries Society Symposium, v. 47, p. 263-287.

Brown, L.R., Gray, R.H., Hughes, R.M., and Meador, M.R., 2005, Introduction to effects of urbanization on stream ecosystems, in Brown, L.R., Gray, R.H., Hughes, R.M., and Meador, M.R., eds., Effects of urbanization on stream ecosystems: Bethesda, Maryland, American Fisheries Society Symposium, v. 47, p. 1-8.

Burkhardt, M.R., Zaugg, S.D., Smith, S.G., and ReVello, R.C., 2006, Determination of wastewater compounds in sediment and soil by pressurized solvent extraction, solid-phase extraction, and capillary-column gas chromatography/ mass spectrometry: U.S. Geological Survey Techniques and Methods, book 5, chap. B2, 40 p.

Carter, J.L., and Fend, S.V., 2005, Setting limits - the development and use of factor-ceiling distributions for an urban assessment using macroinvertebrates, in Brown, L.R., Gray, R.H., Hughes, R.M., and Meador, M.R., eds., Effects of urbanization on stream ecosystems: Bethesda, Maryland, American Fisheries Society Symposium, v. 47, p. 179-191.

Chapman, S.S., Omernik, J.M., Freeouf, J.A., Huggins, D.G., McCauley, J.R., Freeman, C.C., Steinauer, G., Angelo, R.T., and Schlepp, R.L., 2001, Ecoregions of Nebraska and Kansas: Information available on Web, accessed June 2009, at ftp://ftp.epa.gov/wed/ecoregions/ks_ne/ksne_front.pdf

Childress, C.J.O., Foreman, W.T., Connor, B.F., and Maloney, T.J., 1999, New reporting procedures based on longterm method detection levels and some considerations for interpretations of water-quality data provided by the U.S. Geological Survey National Water Quality Laboratory: U.S. Geological Survey Open File Report 99-193, 19 p.

Clarke, K.R., and Ainsworth, M., 1993, A method of linking multivariate community structure to environmental variables: Marine Ecological Progress Series, v. 92, p. 205-219.

Clarke, K.R., and Gorley, R.N., 2006, PRIMER ver. 6-user manual-Plymouth Routines in Multivariate Ecological Research: Plymouth, United Kingdom. PRIMER-E, Ltd., $190 \mathrm{p}$. 
Clarke, K.R., and Warwick, R.M., 2005, Change in marine communities-an approach to statistical analysis and interpretation ( $2 \mathrm{~d}$ ed.): Plymouth, United Kingdom, Primer-E Ltd.

Clausen, B., and Biggs, B.J., 1997, Relationship between benthic biota and hydrological indices in New Zealand streams: Freshwater Biology, v. 38, p. 327-342.

Coffman, W.P. and Ferrington, L.C., Jr., 1996, Chironomidae in Meritt, R.W., and Cummings, K.W., eds., An introduction to the aquatic insects of North America (3rd ed.): Kendall/ Hunt Publishing Company, Dubuque, Iowa, p. 635-754.

Cottingham, P., Walsh, C., Rooney, G., and Fletcher, T., 2004, Urbanization impacts on stream ecology-from syndrome to cure: Outcomes of workshops held at symposium on urbanization and stream ecology, December 8-10, 2003, Melbourne University Cooperative Research Centre for Freshwater Ecology, Melbourne, Australia, 29 p.

Cuffney, T.F., 2003, User's manual for the National WaterQuality Assessment Program Invertebrate Data Analysis System (IDAS) software, ver. 3: U.S. Geological Survey Open File Report 03-172, 103 p.

Cuffney, T.F., Zappia, H., Giddings, E.M.P., and Coles, J.F., 2005, Urbanization effects on benthic macroinvertebrate assemblages in contrasting environmental settings-Boston, Birmingham, and Salt Lake City, in Brown, L.R., Gray, R.H., Hughes, R.M., and Meador, M.R., eds., Effects of urbanization on stream ecosystems: Bethesda, Maryland, American Fisheries Society Symposium, v. 47, p. 361-407.

Davenport, T.E., and Kelly, M.H., 1983, Water resource data and preliminary trend analysis for the Highland Silver Lake Monitoring and Evaluation Project, Madison County, Illinois, phase II: Springfield, Illinois Environmental Protection Agency, Report No. IEPA/WPC/83-013, variously paged.

Davies, S.P., and Jackson, S.K., 2006, The biological condition gradient - a conceptual model for interpreting detrimental change in aquatic ecosystems: Information available on Web, accessed June 10, 2006, at http://www.ci.uri.edu/ Projects/RI-Monitoring/Docs/DaviesJacksonBCG_MasterOct12'04.pdf

Deacon, J.R., Soule, S.A., and Smith, T.E., 2005, Effects of urbanization on stream quality at selected sites in the seacoast region in New Hampshire, 2001-03: U.S. Geological Survey Scientific Investigations Report 2005-5103, 18 p.

Delwiche, L.D., and Slaughter, S.J., 1998, The little SAS book - a primer: Cary, North Carolina, SAS Institute, Inc., $228 \mathrm{p}$.
DeShon, J.E., 1995, Development and application of the Invertebrate Community Index (ICI), in Davis, W.S., and Simon, T.P., eds., Biological assessment and criteria - tools for water resource planning and decision making: Boca Raton, Florida., Lewis Publishers, p. 217-243.

Devlin, D.L., and McVay, K.A., 2001, Suspended solids-a water quality concern for Kansas: Kansas State University Agricultural Experiment Station and Cooperative Extension Service, TMDL Fact Sheet No. 6, 2 p.

Eisler, R., 1987, Polycyclic aromatic hydrocarbon hazards to fish, wildlife, and invertebrates - a synoptic review: U.S. Fish and Wildlife Service Biological Report 85(1.11), 81 p.

Erickson, J.W., Kenner, S.J., and Barton, B.A., 2005, Physiological stress responses of Brown trout to stormwater runoff events in Rapid Creek, Rapid City, South Dakota, in Brown, L.R., Gray, R.H., Hughes, R.M., and Meador, M.R., eds., Effects of urbanization on stream ecosystems: Bethesda, Maryland, American Fisheries Society Symposium, v. 47, p. $117-132$.

Feminella, J.W., 1996, Comparison of benthic macroinvertebrate assemblages in small streams along a gradient of flow permanence: Journal of the North American Benthological Society, v. 15, no. 4, p. 651-669.

Fend, S.V., Carter, J.L., and Kearns, F.R., 2005, Relationships of field habitat measurements, visual habitat indices, and land cover to benthic macroinvertebrates in urbanized streams of the Santa Clara Valley, California, in Brown, L.R., Gray, R.H., Hughes, R.M., and Meador, M.R., eds., Effects of urbanization on stream ecosystems: Bethesda, Maryland, American Fisheries Society Symposium, v. 47, p. 193-212.

Fishman, M.J., and Friedman, L.C., 1989, Methods for determination of inorganic substances in water and fluvial sediments: U.S. Geological Survey Techniques of Water Resources Investigations, book 5, chap. A1, 545 p.

Fitzpatrick, F.A., Diebel, M.W., Harris, M.A., Arnold, T.L., Lutz, M.A., and Richards, K.D., 2005, Effects of urbanization on the geomorphology, habitat, hydrology, and fish index of biotic integrity of streams in the Chicago area, Illinois and Wisconsin, in Brown, L.R., Gray, R.H., Hughes, R.M., and Meador, M.R., eds., Effects of urbanization on stream ecosystems: Bethesda, Maryland, American Fisheries Society, Symposium, v. 47, p. 87-115.

Fitzpatrick, F.A., Waite, I.R., D’Arconte, P.J., Meador, M.R., Maputin, M.A., and Gurtz, M.E., 1998, Revised methods for characterizing stream habitat in the National Water Quality Assessment Program: U.S. Geological Survey Water-Resources Investigations Report 09-4052, 67 p. 
Fore, L.S., Karr, J.R., and Conquest, L.L., 1994, Statistical properties of an index of biological integrity used to evaluate water resources: Canada Journal of Fish Aquatic Science, v. 51, p. 1,077-1,087.

Foreman, W.T., Connor, B.F., Furlong, E.T., Vaught, D.G., and Merten, L.M., 1995, Methods of analysis by the U.S. Geological Survey National Water Quality Laboratory-determination of organochlorine pesticides and polychlorinated byphenyls in bottom sediment by dual capillary column gas chromatography with electron-capture detection: U.S. Geological Survey Open-File Report 95-140, 78 p.

Frissell, C.A., Liss, W.J., Warren, C.E., and Hurley, M.D., 1986, A hierarchical framework for stream habitat classification-viewing streams in a watershed context: Environmental Management, v. 10, p. 199-214.

Galli, J., 1996, Rapid Stream Assessment Technique (RSAT) field methods: Washington D.C., Metropolitan Washington Council of Governments, Department of Environmental Programs, $36 \mathrm{p}$.

Graham, J.L., Loftin, K.A., Ziegler, A.C., and Meyer, M.T., 2008, Guidelines for design and sampling for cyanobacterial toxin and taste-and-odor studies in lakes and reservoirs: U.S. Geological Survey Scientific Investigations Report 2008-5038, 39 p.

Guy, H.P., 1969, Laboratory theory and methods for sediment analysis: U.S. Geological Survey Techniques of Water Resources Investigations, book 5, chap. C1, 58 p.

Hambrook-Berkman, J.A. and Canova, M.G., 2007, Algal biomass indicators: U.S. Geological Survey Techniques of Water-Resources Investigations, book 9, chap. A7, sec. 7.4, available on Web, accessed December 17, 2007, at http:// pubs.water.usgs.gov/twri9A7

Harrelson, C.C., Rawlins, C.L., and Potyondy, J.P., 1994, Stream channel reference sites - an illustrated guide to field technique: Fort Collins, Colorado, U.S. Department of Agriculture, U.S. Forest Service, Rocky Mountain Forest and Range Experiment Station, General Technical Report RM-245, $61 \mathrm{p}$.

Herlihy, A.T., Stoddard, J.L., and Johnson, C.B., 1998, The relationship between stream chemistry and watershed land cover data in the mid-Atlantic region, U.S.: Water, Air, and Soil Pollution, v. 105, p. 377-386.

Hillebrand, H., Dürselen, C.D., Kirschtel, D., Pollinger, U., and Zohary, T., 1999, Biovolume calculation for pelagic and benthic microalgae: Journal of Phycology, v. 25, p. $403-424$.

Hilsenhoff, W.L., 1987, An improved biotic index of organic stream pollution: Great Lakes Entomology, v. 20, p. 31-39.
Horner, R.R., Welch, E.B., and Veenstra, R.B., 1983, Development of nuisance periphytic algae in laboratory streams in relation to enrichment and velocity, in Wetzel, R.G., ed., Periphyton of freshwater ecosystems: The Hague, The Netherlands, Dr. W. Junk Publishers, p. 121-131.

Hornig, C.E., Bayer, C.W., Twidwell, S.R., Davis, J.R., Kleinsasser, R.J., Linam, G.W., and Mayes, K.B., 1995, Development of regionally based biological criteria in Texas, in Davis, W.S., and Simon, T.P., eds., Biological assessment and criteria-tools for water resource planning and decision making: Boca Raton, Florida, Lewis Publishers, chap. 10, p. $145-152$.

Horowitz, A.J., Elrick, K.A., and Smith, J.J., 2001, Estimating suspended sediment and trace element fluxes in large river basins-methodological considerations as applied to the NASQAN programme: Hydrological Processes, v. 15, no. 7, p. $1,169-1,208$.

Huggins, D.G., and Moffett, M.F., 1988, Proposed biotic and habitat indices for use in Kansas streams: Lawrence, Kansas, Kansas Biological Survey, Report 35, 183 p.

Kansas Department of Health and Environment, 2000, Division of Environment quality management plan, part IIIstream biological monitoring program, quality assurance management plan: Topeka, Kansas, Bureau of Environmental Field Services, Technical Services section, 42 p.

Kansas Department of Health and Environment, 2006, Kansas-Lower Republican Basin total maximum daily load, waterbody-Mill Creek watershed, water quality impairment-biology: Information available on Web, accessed October 10, 2006, at http://www.kdheks.gov/tmdl/2006/ new_mill_creek_bio_tmdl.pdf

Kansas Department of Health and Environment, 2007, Stream probabilistic monitoring program - quality assurance management plan: Information available on Web, accessed March 2009, at http://www.kdheks.gov/environment/ qmp_2000/download/2007/SPMP_QAMP.pdf

Kansas Department of Health and Environment, 2008, Kansas integrated water quality assessment: Information available on Web, accessed June 2009, at http://www.kdheks.gov/befs/ download/2008IR_040108FINAL.pdf

Karr, J.R., Fausch, K.D., Angermeier, P.L., Yant, P.R., and Schlosser, L.J., 1986, Assessing biological integrity in running waters - a method and its rationale: Illinois Natural History Survey, Special Publication 5, 28 p.

Karr, J.R., 1993, Defining and assessing ecological integrity-beyond water quality: Environmental Toxicology and Chemistry, v. 12, p. 1,521-1,531. 
Karr, J.R., and Kerans, B.L., 1991, Components of biological integrity - their definition and use in development of an invertebrate IBI: Chicago, Illinois, U.S. Environmental Protection Agency, Environmental Sciences Division, Report 905-R-92-003, $16 \mathrm{p}$.

Karr, J.R., and Yoder, C.O., 2004, Biological assessment and criteria improve total maximum daily load decision making: Journal of Environmental Engineering, v. 130, p. 594-604.

Kaufmann, P.R., Levine, P., Robison, E.G., Seeliger, C., and Peck, D.V., 1999, Quantifying physical habitat in wadeable streams: Corvallis, Oregon, U.S. Environmental Protection Agency, Environmental Monitoring and Assessment Program, EPA 620/R-99/003, 149 p.

Kaushal, S.S., Groffman, P.M., Likens, G.E., Belt, K.T., Stack, W.P., Kelly, V.R., Band, L.E., and Fisher, G.T., 2005, Increased salinization of fresh water in the northeastern United States: Proceedings of the National Academy of Sciences, v. 38, p. 13,517-13,520.

Kennen, J.G., Chang, M., and Tracy, B.H., 2005, Effects of landscape change on fish assemblage structure in a rapidly growing metropolitan area in North Carolina, USA, in Brown, L.R., Gray, R.H., Hughes, R.M., and Meador, M.R., eds., Effects of urbanization on stream ecosystems: Bethesda, Maryland, American Fisheries Society Symposium, v. 47, p. 39-52.

Kentucky Division of Water, 1993, Methods for assessing biological integrity of surface waters: Frankfurt, Kentucky, Kentucky Department of Environmental Protection, 182 p.

Kerans, B.L., and Karr, J.R., 1994, A benthic index of biotic integrity (B-IBI) for rivers of the Tennessee Valley: Ecology Applications, v. 4, no. 4, p. 768-785.

Klemm, D.J., Lewis , P. A., Fulk, F., and Lazorchak, J.M., 1990, Macroinvertebrate field and laboratory methods for evaluating the biological integrity of surface waters: Environmental Monitoring Series, USEPA-ORD, EPA/600/490/030.

Knowlton, M.F., 1984, Flow-through microcuvette for fluorometric determination of chlorophyll: Water Research Bulletin, v. 20, p. 1,198-1,205.

Konrad, C.P., and Booth, D.B., 2005, Hydrologic changes in urban streams and their ecological significance, in Brown, L.R., Gray, R.H., Hughes, R.M., and Meador, M.R., eds., Effects of urbanization on stream ecosystems: Bethesda, Maryland, American Fisheries Society Symposium, v. 47, p. 151-177.
Konrad, C.P., Brasher, A.M.D., and May, J.T., 2008, Assessing streamflow characteristics as limiting factors on benthic invertebrate assemblages in streams across the western United States: Freshwater Biology, v. 53, no. 10, p. 1,9831,998 .

Kreis, R.G., Jr., 1988, Integrated study of exposure and biological effects of in-place sediment pollutants in the Detroit River, Michigan - an upper Great Lakes connecting channel: U.S. Environmental Protection Agency, final report to the EPA Office of Research and Development, EPA ERLDuluth, Minnesota, and EPA LLRS-Grosse Ile, Michigan, $153 \mathrm{p}$.

Lee, C.J., Mau, D.P., and Rasmussen, T.J., 2005, Effects of nonpoint and selected point contaminant sources on Johnson County streams, northeastern Kansas, October 2002 through June 2004: U.S. Geological Survey Scientific Investigations Report 2005-5144, 186 p.

Lenat, D.L., 1988, Water quality assessment of streams using a qualitative collection method for benthic invertebrates: Journal of the North American Benthological Society, v. 7, p. 222-233.

Lenat, D.L., 1993, A biotic index for the southeastern United States - derivation and list of tolerance values, with criteria for assigning water-quality ratings - 1993: Journal of the North American Benthological Society, v. 12, p. 279-290.

Leopold, L.B., Wolman, M.G., and Miller, J.P., 1992, Fluvial processes in geomorphology: New York, Dover Publications, Inc., $522 \mathrm{p}$.

Limburg, K.E., Stainbrook, K.M., Erickson, J.D., and Gowdy, J.M., 2005, Urbanization consequences - case studies in the Hudson River watershed, in Brown, L.R., Gray, R.H., Hughes, R.M., and Meador, M.R., eds., Effects of urbanization on stream ecosystems: Bethesda, Maryland, American Fisheries Society Symposium, v. 47, p. 23-37.

Lohman, K., Jones, J.R., and Perkins, B.D., 1992, Effects of nutrient enrichment and flood frequency on periphyton biomass in northern Ozark streams: Canadian Journal of Fisheries and Aquatic Sciences, v. 49, no. 6, p. 1,198-1,205.

Lowe, R.L., and LaLiberte, G.D., 2007, Benthic stream algae - distribution and structure, in Hauer, F.R., and Lamberti, G.A., eds., Methods in stream ecology ( 2 ed.): Boston, Massachusetts, Academic Press, p. 327-380, 877 p.

Lowe, R.L., and Pan, Y., 1996, Benthic algal communities as biological monitors, in Stevenson, R.J., Bothwell, M.L., and Lowe, R.L., eds., Algal ecology: San Diego, California, Academic Press, p. 705-739. 
MacDonald, D.D., Ingersoll, C.G., and Berger, T.A., 2000, Development and evaluation of consensus-based sediment quality guidelines for freshwater ecosystems: Archives of Environmental Contamination and Toxicology, v. 39, p. 20-31.

Mahler, B.J., Van Metre, P.C., Bashara, T.J., Wilson, J.T., and Johns, D.A., 2005, Parking lot sealant-an unrecognized source of urban polycyclic aromatic hydrocarbons: Environmental Science and Technology, v. 39, p. 5,560-5,566.

McNabb, C.D., 1960, Enumeration of freshwater phytoplankton concentrated on the membrane filter: Limnology and Oceanography, v. 5, no. 1, p. 57-61.

Mid-America Regional Council, 2002, Long-range forecast for the Kansas City metropolitan area, 2002: Information available on Web, accessed December 17, 2004, at http://www. metrodataline.org/Forecasts/2002\%20Long\%Range\%20 Forecast.slx

Missouri Department of Natural Resources, 2001, Biological criteria for wadeable perennial streams of Missouri: Jefferson City, Missouri, Air \& Land Protection Division, Environmental Services Program, 22 p.

Moulton, S.R., II, Carter, J.L., Grotheer, S.A., Cuffney, T.F., and Short, T.M., 2000, Methods of analysis by the U.S. Geological Survey National Water Quality Laboratoryprocessing, taxonomy, and quality control of benthic macroinvertebrate samples: U.S. Geological Survey Open-File Report 2000-212, 49 p.

Moulton, S.R., II, Kennen, J.G., Goldstein, R.M., and Hambrook, J.A., 2002, Revised protocols for sampling algal, invertebrate, and fish communities as part of the National Water-Quality Assessment Program: U.S. Geological Survey Open File Report 02-150, 75 p.

Murdock, J., Roelke, D., and Gelwick, F., 2004, Interactions between flow, periphyton, and nutrients in a heavily impacted urban stream - implications for stream restoration effectiveness: Ecological Engineering, v. 22, p. 197-207.

National Oceanic and Atmospheric Administration, 2007, Climatological data summary for Olathe, Kansas, National Climatic Data Center: Information available on the Web, accessed August 2007, at http://www.ncdc.noaa.gov/oa/climate/stationlocator.html

Natural Resources Conservation Service, 1998, Stream visual assessment protocol: U.S. Department of Agriculture, National Water and Climate Center Technical Note 99-1, $36 \mathrm{p}$.

O'Connor, H.G., 1971, Johnson County geohydrology: Kansas Geological Survey, information available on Web, accessed June 25, 2007, at http://www.kgs.ku.edu/General/Geology/ Johnson/index.html
Oklahoma Conservation Commission, 1993, Development of rapid bioassessment protocols for Oklahoma utilizing characteristics of the diatom community: Oklahoma City, Oklahoma, Oklahoma Conservation Commission, 104 p.

Olrik, K., Blomqvist, P., Brettum, P., Cronberg, G., and Eloranta, P., 1998, Methods for quantitative assessment of phytoplankton in freshwaters, part I: Naturvardsverket, Stockholm, Report 4860, 86 p.

Omernik, J.M., 1995, Ecoregions - a spatial framework for environmental management, in Davis, W.S., and Simon, T.P., eds., Biological assessment and criteria - tools for water resource planning and decision making: Boca Raton, Florida, Lewis Publishers, chap. 5, p. 49-62.

Patrick Center for Environmental Research, 1988, Diatom cleaning by nitric acid digestion: The Academy of Natural Sciences of Philadelphia, Protocol No. P-13-02, 39 p.

Paul, M.J., and Meyer, J.L., 2001, Streams in the urban landscape: Annual Review of Ecology and Systematics, v. 32, p. 333-365.

Perry, C.A., Wolock, D.M., and Artman, J.A., 2004, Estimates of flow duration, mean flow, and peak-discharge frequency values for Kansas stream locations: U.S. Geological Survey Scientific Investigations Report 2004-5033, 219 p.

Platts, W.S., Megahan, W.F., and Minshall, G.W., 1983, Methods for evaluating stream, riparian, and biotic conditions: Ogden, Utah, U.S. Department of Agriculture, U.S. Forest Service, General Technical Report INT-138, 70 p.

Plafkin, J.L., Barbour, M.T., Porter, K.D., Gross, S.K., and Hughes, R.M., 1989, Rapid Bioassessment protocols for use in streams and rivers: Benthis macroinvertebrates and fish, Washington, D.C., U.S. Environmental Protection Agency, Office of Water Regulations and Standards, EPA 440-4-89001.

Plinsky, R.O., Zimmerman, J.L., Dickey, H.P., Jorgensen, G.N., Fenwick, R.W., and Roth, W.E., 1975, Soil survey of Johnson County, Kansas: U.S. Department of Agriculture, Soil Conservation Service, $93 \mathrm{p}$.

Poff, N.L., and Ward, J.V., 1989, Implications of streamflow variability and predictability for lotic community structurea regional analysis of streamflow patterns: Canadian Journal of Fisheries and Aquatic Sciences, v. 46, p. 1,805-1,818.

Pope, L. M., 2005, Assessment of contaminated streambed sediment in the Kansas part of the historic tri-state lead and zinc mining district, Cherokee County, 2004: U.S. Geological Survey Scientific Investigations Report 2005-5251, $61 \mathrm{p}$. 
Porter, S.D., 2008, Algal attributes-An autecological classification of taxa collected by the National Water-Quality Assessment Program: U.S. Geological Survey Data Series 329, available on Web, accessed March 2009, at http://pubs. usgs.gov/ds/ds329

Porter, S.D., Mueller, D.K., Spahr, N.E., Munn, M.D., and Dubrovsky, N.M., 2008, Efficacy of algal metrics for assessing nutrient and organic enrichment in flowing waters: Freshwater Biology, v. 53, p. 1,036-1,054.

Poulton, B.C., Monda, D.P., Woodward, D.F., Wildhaber, M.L., and Brumbaugh, W.G., 1995, Relations between benthic community structure and metals concentrations in aquatic macroinvertebrates - Clark Fork River, Montana: Journal of Freshwater Ecology, v. 10, no. 3, p. 277-293.

Poulton, B.C., Rasmussen, T.J., and Lee, C.J., 2007, Assessment of biological conditions at selected stream sites in Johnson County, Kansas, and Cass and Jackson Counties, Missouri, 2003 and 2004: U.S. Geological Survey Scientific Investigations Report 2007-5108, 68 p.

Radtke, D.B., revised 2005, Bottom-material samples: U.S. Geological Survey Techniques of Water-Resources Investigations, book 9, chap. A8, available on Web, accessed April 10, 2009, at http://pubs.water.usgs.gov/twri9A8/.

Rasmussen, T.J., Lee, C.J., and Ziegler, A.C., 2008, Estimation of constituent concentrations, densities, loads, and yields in streams in Johnson County, northeastern Kansas, using regression models and continuous water-quality monitoring, October 2002 through December 2006: U.S. Geological Survey Scientific Investigations Report 2008-5014, 103 p.

Richter, B.D., Baumgartner, J.V., Powell, J., and Braun, D.P., 1996, A method for assessing hydrologic alteration within ecosystems: Conservation Biology, v. 10, p. 1,163-1,174.

Roesner, L.A., and Bledsoe, B.P., 2003, Physical effects of wet weather flows on aquatic habitats - present knowledge and research needs: Alexandria, Virginia, Water Environmental Research Foundation, Report 00-WSM-4, 200 p.

Rosen, B.H., 1995, Use of periphyton in the development of biocriteria, in Davis, W.S., and Simon, T.P., eds., Biological assessment and criteria: Boca Raton, Florida, Lewis Publishers, p. 209-215.

Rosenberg, D.M., and Resh, V.H., 1993, Introduction to freshwater biomonitoring and benthic macroinvertebrates, in Rosenberg, D.M., and Resh, V.H., eds., Freshwater biomonitoring and benthic macroinvertebrates: New York, Chapman and Hall, Inc., p. 1-9.

Roy, A.H., Faust, C.L., Freeman, M.C., and Meyer, J.L., 2005, Reach-scale effects of riparian forest cover on urban stream ecosystems: Canadian Journal of Fisheries Aquatic Science, v. 62 , p. 2,312-2,329.
Sartory, D.P., and Grobbelar, J.U., 1986, Extraction of chlorophyll- $a$ from freshwater phytoplankton for spectrophotometric analysis: Hydrobiologia, v. 114, p. 117-187.

Schoewe, W.H., 1949, The geography of Kansas: Transactions of the Kansas Academy of Science, v. 52, no. 3, p. 261-333.

Schumm, S.A., 1963, Sinuousity of alluvial rivers on the Great Plains: Geological Society of America Bulletin, v. 74, p. $1,089-1,100$.

Scroggins, M., McClintock, N.L., Gosselink, L., and Bryer, P., 2007, Occurrence of polycyclic aromatic hydrocarbons below coal-tar-sealed parking lots and effects on stream benthic macroinvertebrate communities: Journal of the North American Benthological Society, v. 26, no. 4, p. 694-707.

Sokel, R.R., and Rohlf, F.J., 1995, Biometry: The principles and practice of statistics in biological research (3 ed.): New York, W.H. Freeman and Company, 887 p.

Southerland, M.T., and Stribling, J.B., 1995, Status of biological criteria development and implementation, in Davis, W.S., and Simon, T.P., eds., Biological assessment and criteria - tools for water resource planning and decision making: Boca Raton, Florida, Lewis Publishers, p. 81-96.

Steinman, A.D., Lamberti, G.A., and Leavitt, P.R., 2006, Biomass and pigments of benthic algae in Haver, F.R., and Lamberti, G.A., eds., Methods in stream ecology ( $2 \mathrm{~d}$ ed.): Burlington, Massachusetts, Academic Press, 877 p.

Stevenson, R.J., 1997, Scale-dependent determininants and consequences of benthic algal heterogeneity: Journal of the American Benthological Society, v. 16, no. 1, p. 248-262.

Stevenson, R.J., and Bahls, L.L., 1999, Periphyton protocols, in Barbour, M.T., Gerritson, J., Snyder, B.D., and Stribling, J.B., eds., Rapid bioassessment protocols for use in streams and wadeable rivers - periphyton, benthic macroinvertebrates, and fish ( $2 \mathrm{~d}$ ed.): Washington, D.C., U.S. Environmental Protection Agency, Office of Water, 841-B-99-002, p. $6 / 1-6 / 23$.

Stevenson, R.J., and Rollins, S.L., 2007, Ecological assessments with benthic algae, in Hauer, F.R., and Lamberti, G.A., eds., Methods in stream ecology (2d ed.): Burlington, Massachusetts, Academic Press, p. 785-804, 877 p.

Stewart, D.W., Rea, A.H., and Wolock, D.M., 2006, USGS streamgages linked to the medium resolution NHD: U.S. Geological Survey Data Series 195, metadata report, data available on Web, accessed March 2008, at http://water. usgs.gov/GIS/metadata/usgswrd/XML/streamgages.xml 
Tate, C.M., Cuffney, T.F., McMahon, G., Giddings, E.M.P., Coles, J.F., and Zappia, H., 2005, Use of an urban intensity index to assess urban effects on streams in three contrasting environmental settings, in Brown, L.R., Gray, R.H., Hughes, R.M., and Meador, M.R., eds., Effects of urbanization on stream ecosystems: Bethesda, Maryland, American Fisheries Society Symposium, v. 47, p. 291-315.

Terrell, C.R., and Perfetti, P.B, 1989, Water quality indicators guide - surface waters: U.S. Department of Agriculture, Soil Conservation Service, SCS-TP-161, 129 p.

U.S. Census Bureau, 2005, State and county quickfacts: Information available on Web, accessed July 20, 2006, at http:// quickfacts.census.gov/qfd/states/20000.html

U.S. Environmental Protection Agency, 2005, Aquatic life ambient water quality criteria - nonylphenol: U.S. Environmental Protection Agency Report, EPA-822-R-05-005, information available on Web, accessed April 2009, at http://epa.gov/waterscience/criteria/nonylphenol/final-doc. $p d f$

U.S. Environmental Protection Agency, 2008, Ecological toxicity information: Information available on Web, accessed September 30, 2008, at http://epa.gov/R5Super/ecology/ $\mathrm{html} /$ toxprofiles.htm

U.S. Geological Survey, 2006, Collection of water samples (ver. 2.0): U.S. Geological Survey Techniques of WaterResources Investigations, book 9, chap. A4, September, available on Web, accessed April 10, 2009, at http://pubs. water.usgs.gov/twri9A4/

Walsh, C.R., Sharpe, A.K., Breen, P.F., and Sonneman, J.A., 2001, Effects of urbanization on streams of the Melbourne region, Victoria, Australia, I. Benthic macroinvertebrate communities: Freshwater Biology, v. 46, p. 535-551.

Walsh, C.R., Roy, A.H., Feminella, J.W., Cottingham, P.D., Groffman, P.M., and Morgan, R.P., II, 2005a, The urban stream syndrome - current knowledge and a search for a cure: Journal of the North American Benthological Society, v. 24 , no. 3 , p. $706-723$.

Walsh, C.R., Fletcher, T.D., and Ladson, A.R., 2005b, Stream restoration in urban catchments through re-designing stormwater systems - looking to the catchment to save the stream: Journal of the North American Benthological Society, v. 24, p. 690-705.
Walters, D.M., Freeman, M.C., Leigh, D.S., Freeman, B.J., and Pringle, C.M., 2005, Urbanization effects on fishes and habitat quality in a southern Piedmont river basin, in Brown, L.R., Gray, R.H., Hughes, R.M., and Meador, M.R., eds., Effects of urbanization on stream ecosystems: Bethesda, Maryland, American Fisheries Society Symposium, v. 47, p. 69-85.

Wang, L., Lyons, J., Kanehl, P., and Bannerman, R., 2001, Impacts of urbanization on stream habitat and fish across multiple spatial scales: Environmental Management, v. 28, p. 255-266.

Washington, H.G., 1984, Diversity, biotic and similarity indices - a review with special reference to aquatic systems: Water Resources, v. 18, no. 6, p. 653-694.

Welch, E.B., Jacoby, J.M., Horner, R.R., and Seeley, M.R., 1988, Nuisance biomass levels of periphytic algae in streams: Hydrobiologia, v. 157, p. 161-168.

Wilkison, D.H., Armstrong, D.J., and Blevins, D.W., 2002, Effects of wastewater and combined sewer overflows on water quality in the Blue River basin, Kansas City, Missouri and Kansas, July 1998-October 2000: U.S. Geological Survey Water-Resources Investigations Report 02-4107, 162 p.

Wilkison, D.H., Armstrong, D.J., Brown, R.E., Poulton, B.C., Cahill, J.D., and Zaugg, S.D., 2005, Water-quality and biologic data for the Blue River Basin, Kansas City metropolitan area, Missouri and Kansas, October 2000 to October 2004: U.S. Geological Survey Data Series 127, 158 p.

Wilkison, D.H., Armstrong, D.J., Norman, R.D., Poulton, B.C., Furlong, E.T., and Zaugg, S.D., 2006, Water-quality in the Blue River Basin, Kansas City metropolitan area, Missouri and Kansas, July 1998 to October 2004: U.S. Geological Survey Scientific Investigations Report 2006-5147, $170 \mathrm{p}$.

Zaugg, S.D., Sandstrom, M.W., Smith, S.G., and Fehlberg, K.M., 1995, Methods of analysis by the U.S. Geological Survey National Water Quality Laboratory-determination of pesticides in water by $\mathrm{C}-18$ solid-phase extraction and capillary-column gas chromatography/mass spectrometry with selected-ion monitoring: U.S. Geological Survey Open-File Report 95-181, $60 \mathrm{p}$. 
Tables 4, 5, and 11 


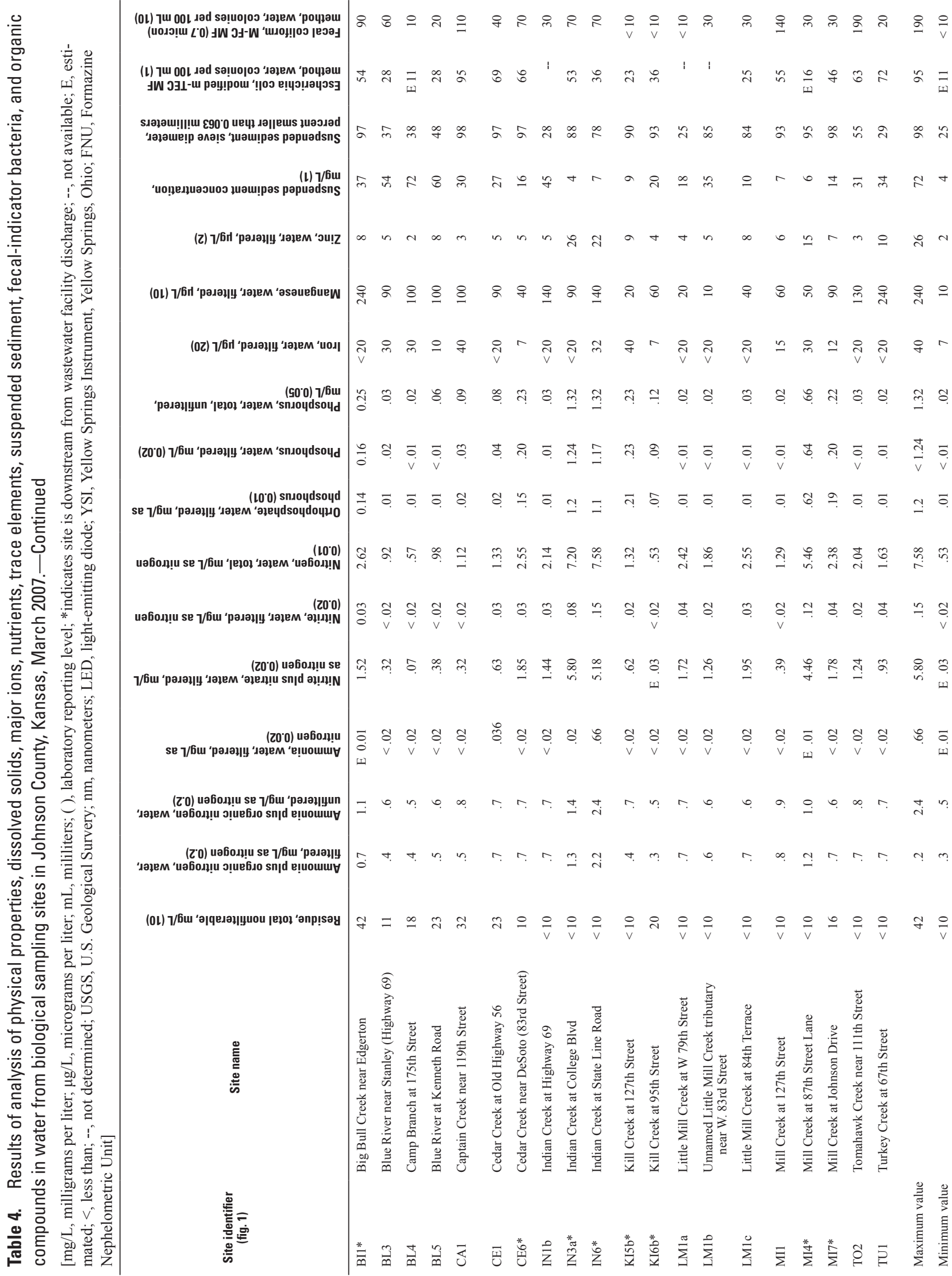




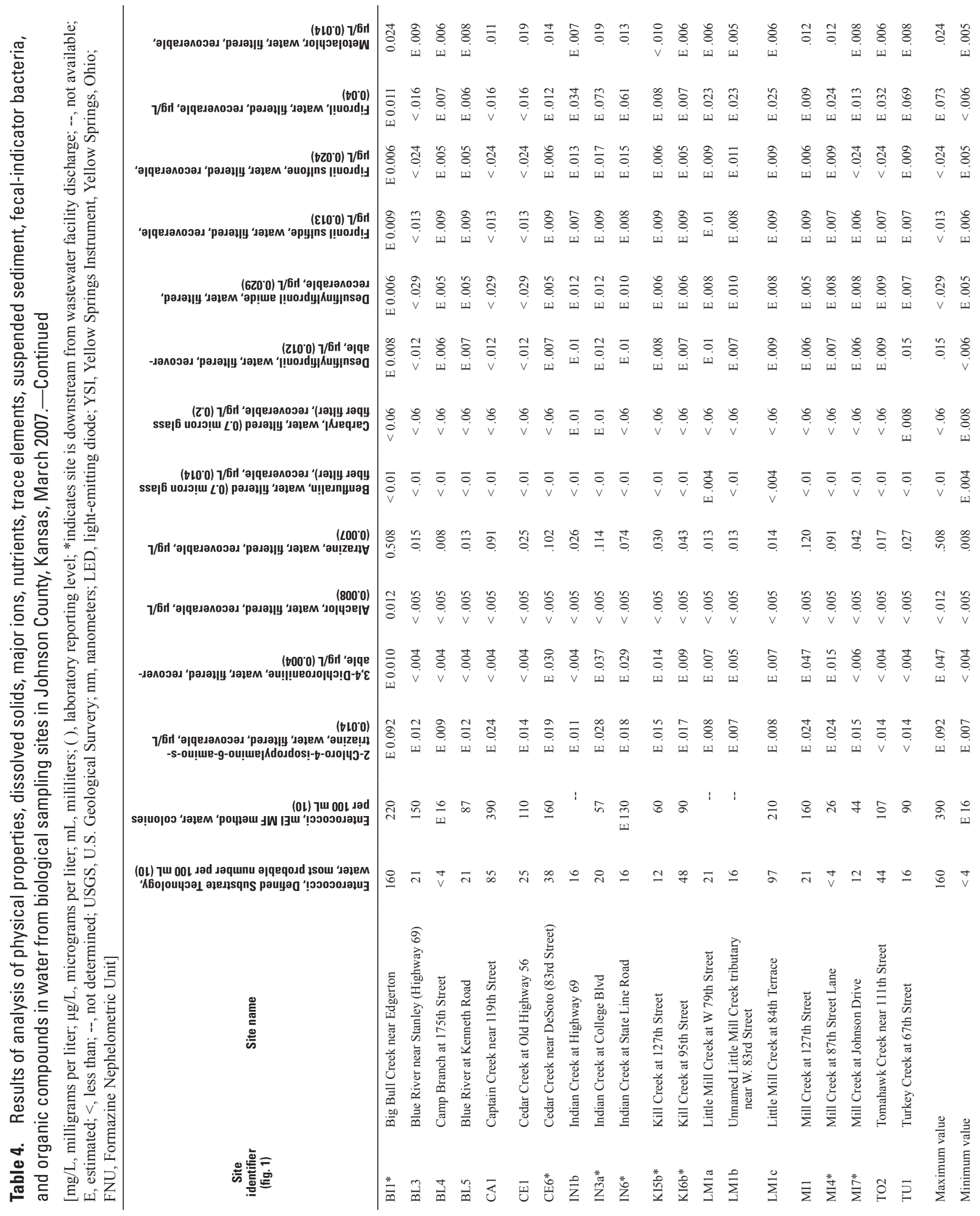




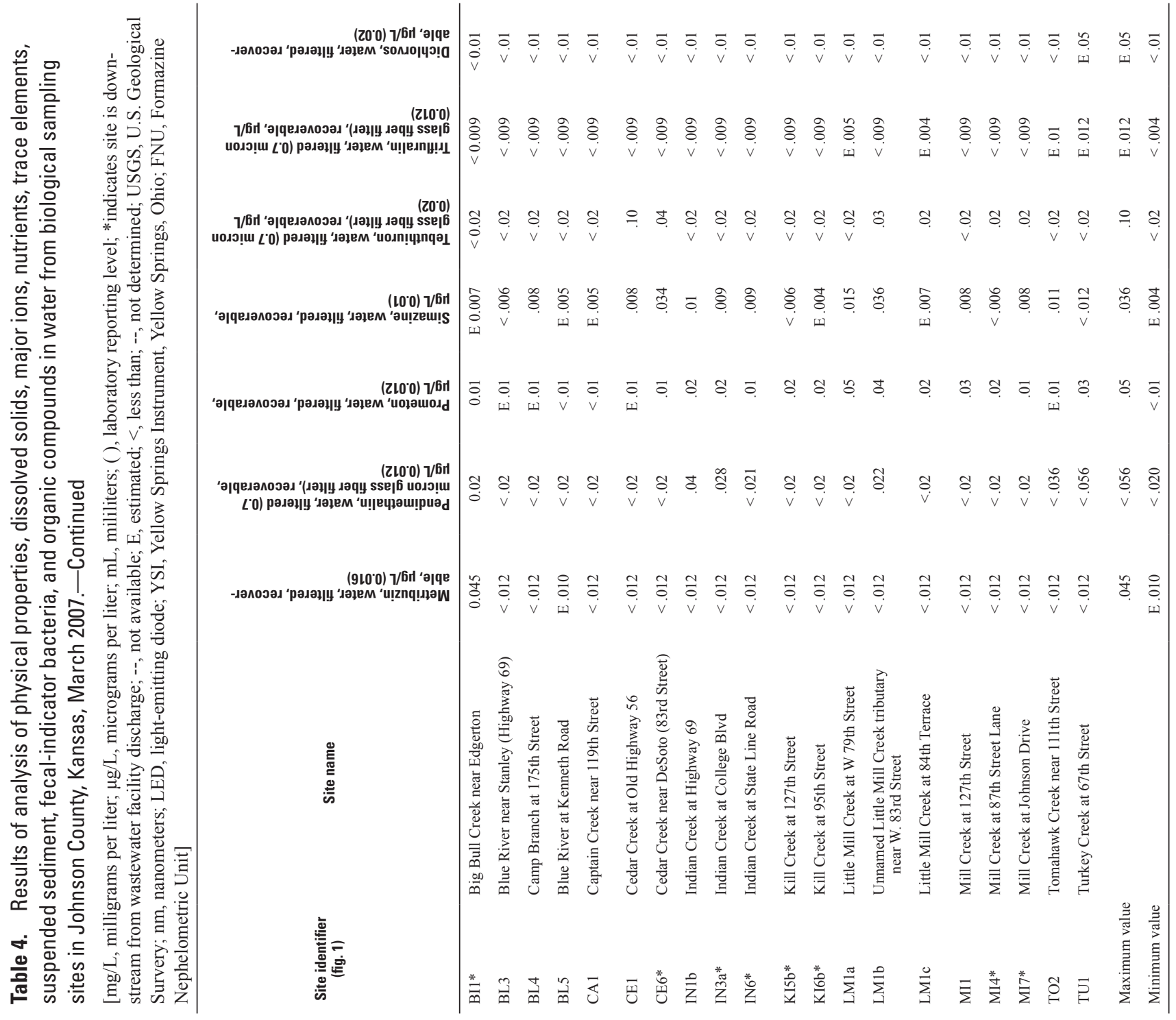




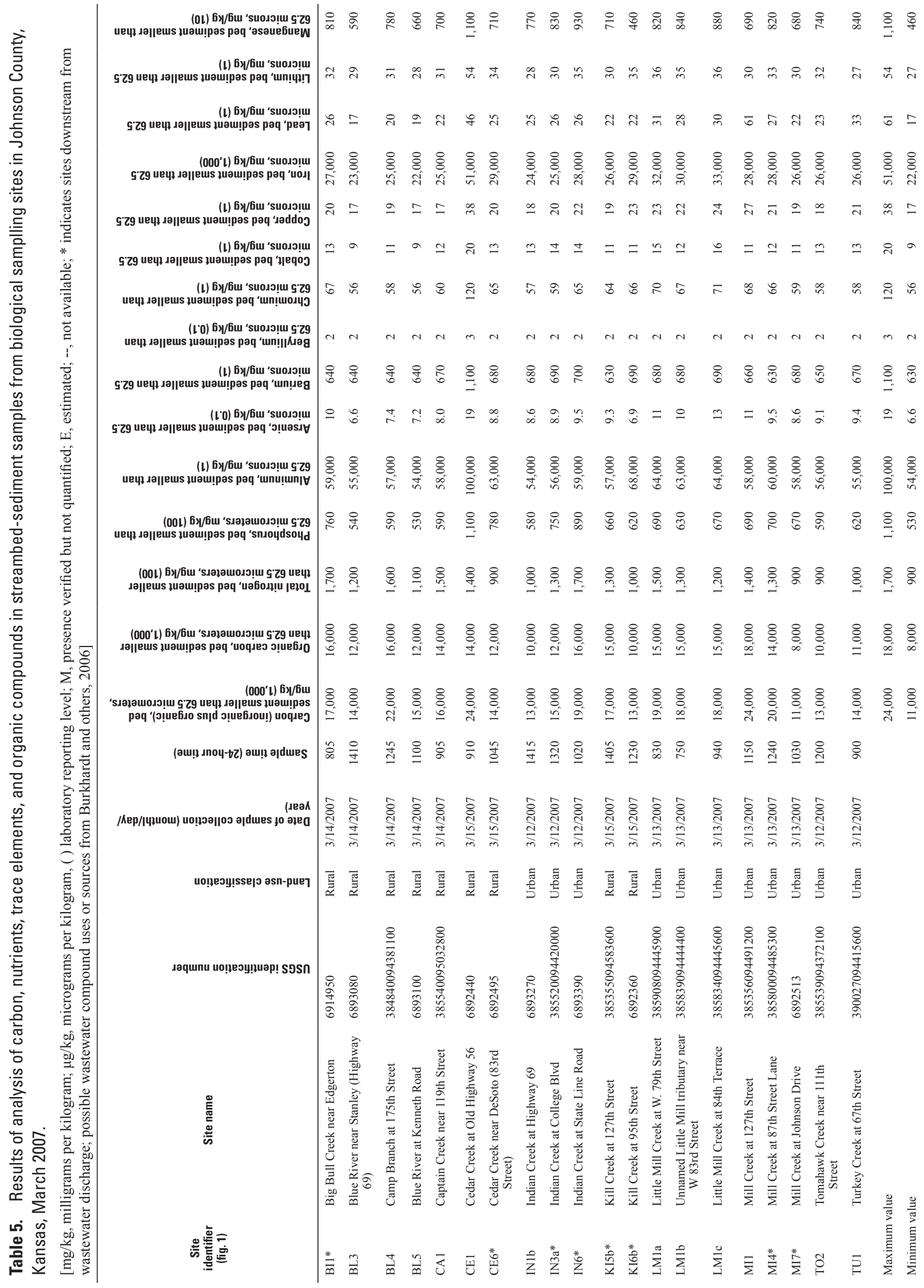




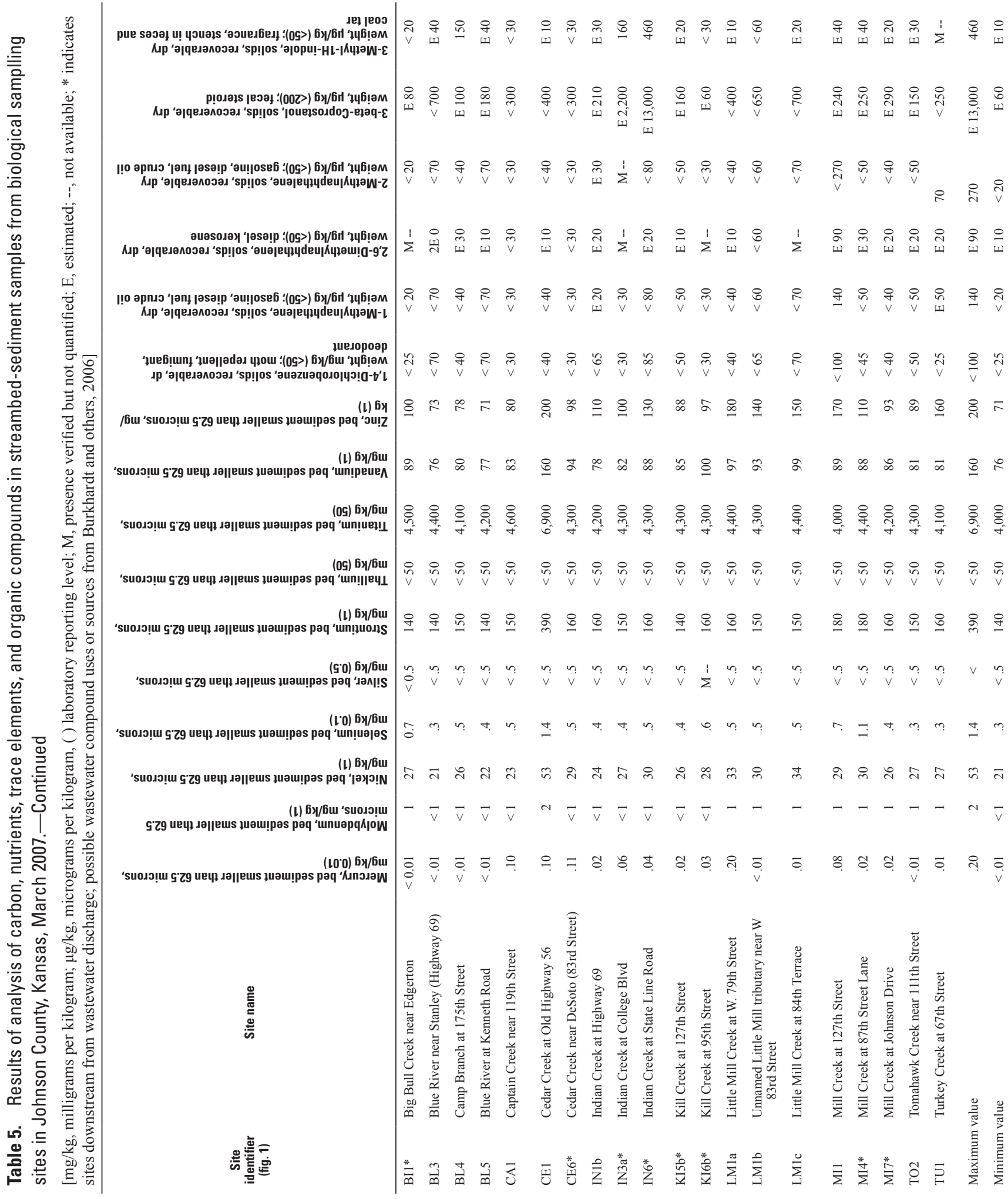




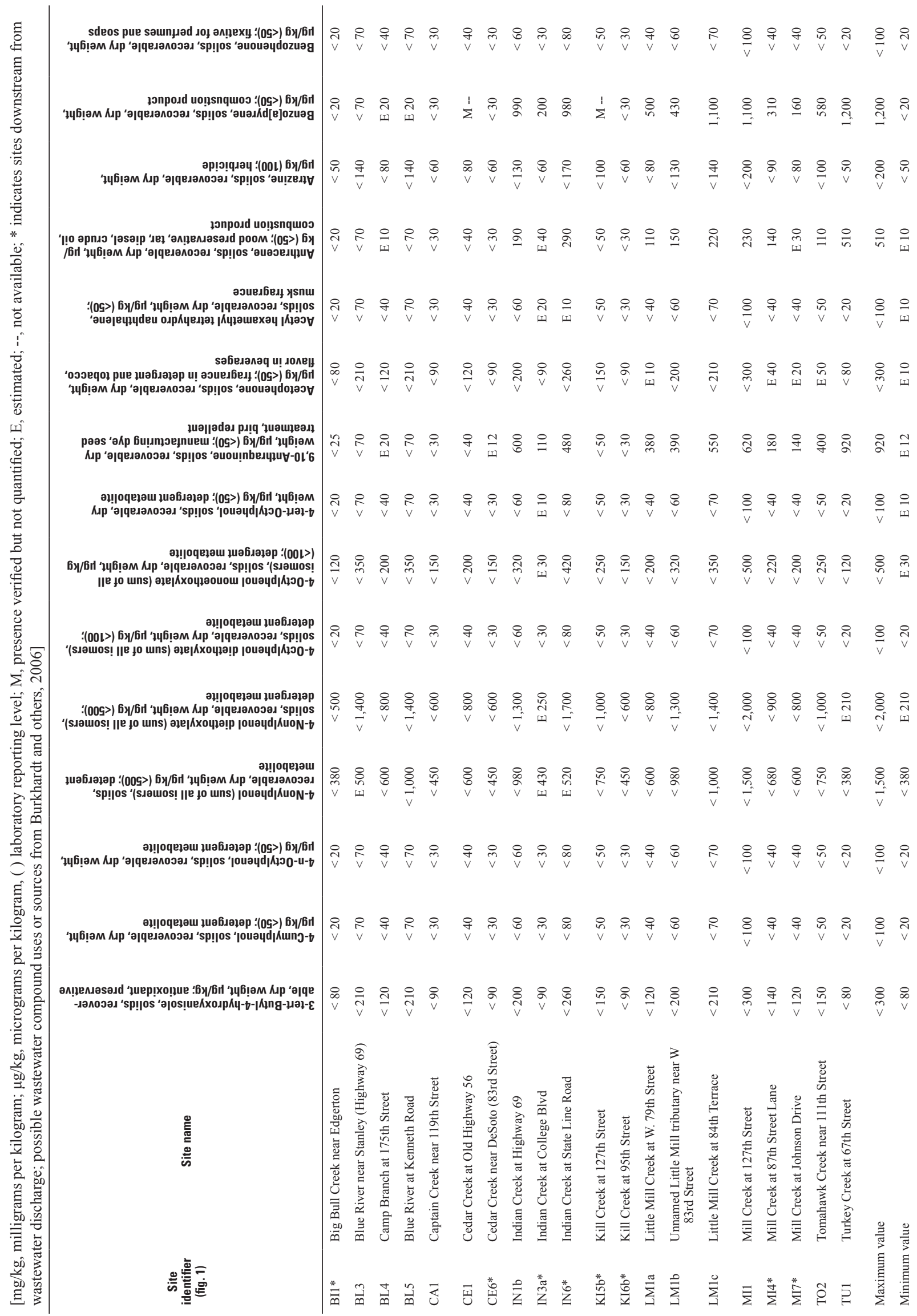




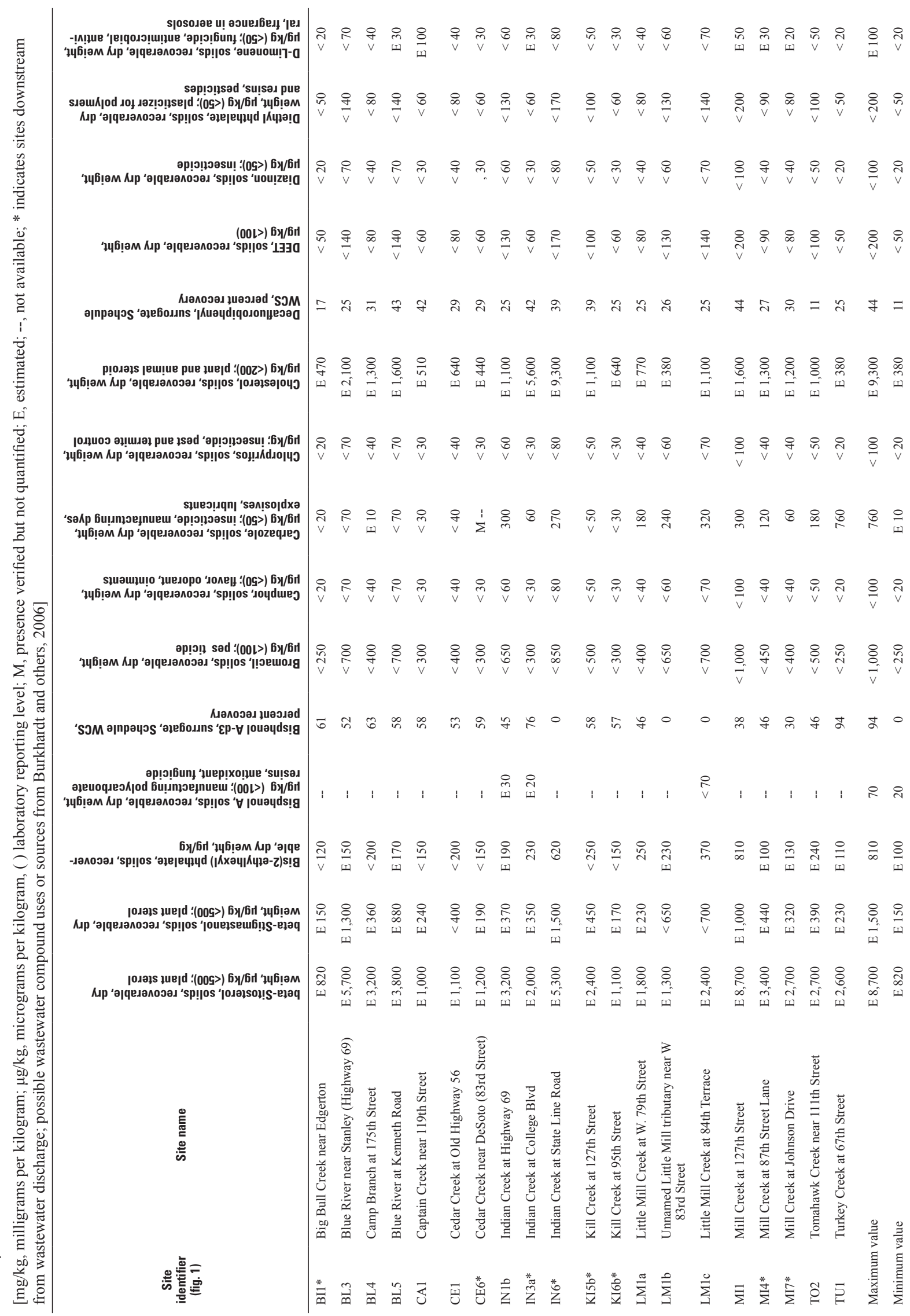




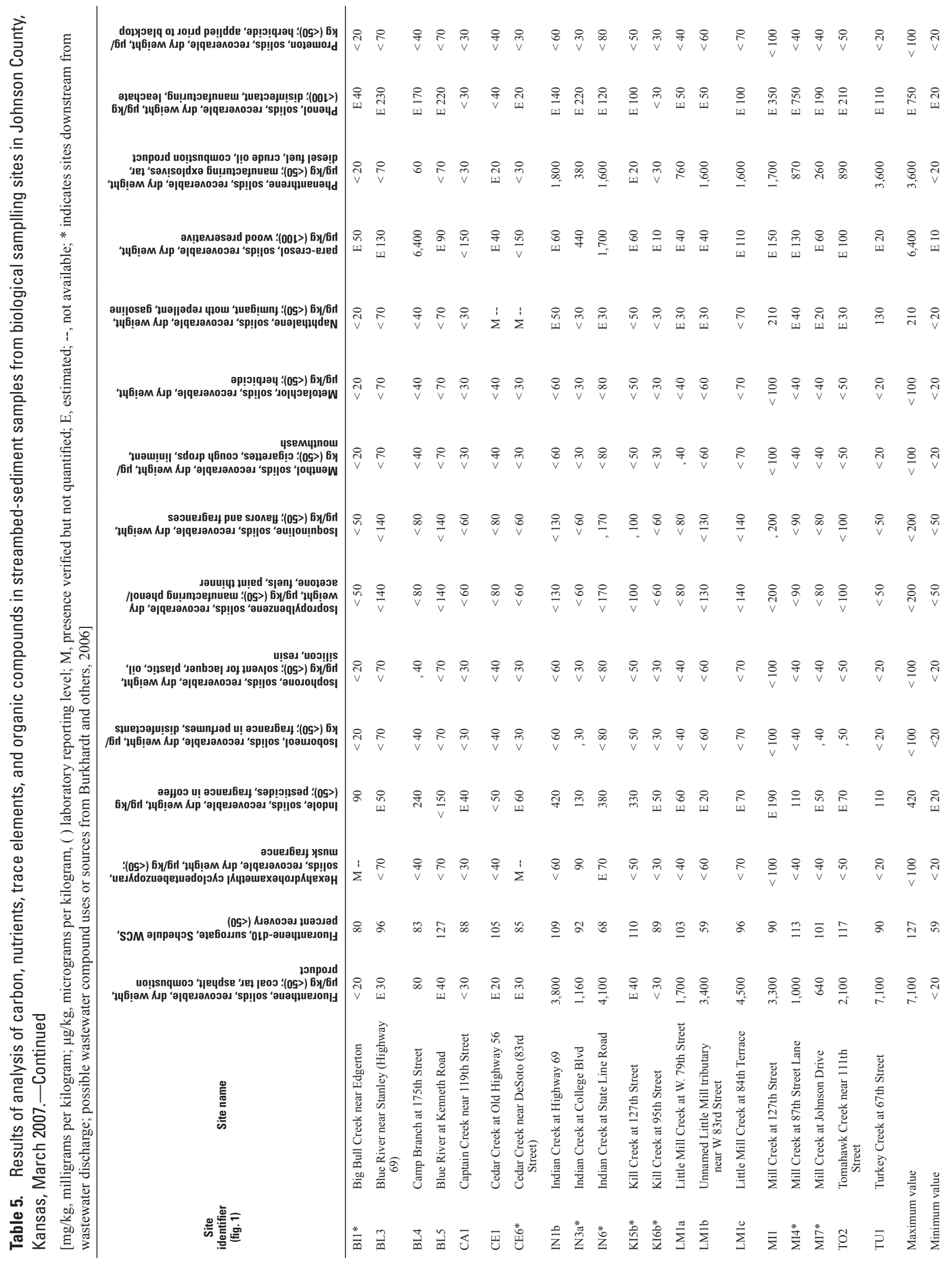




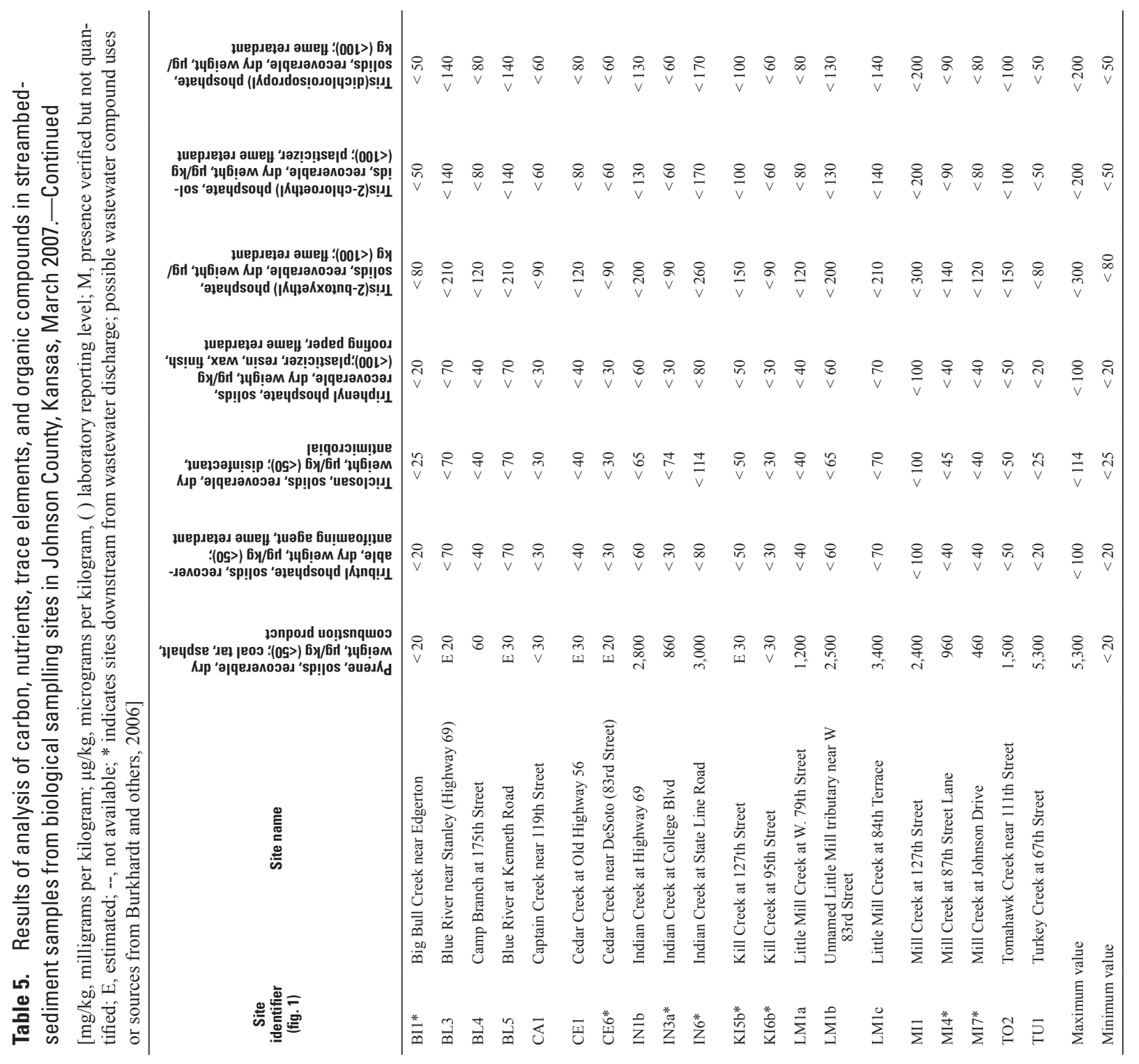




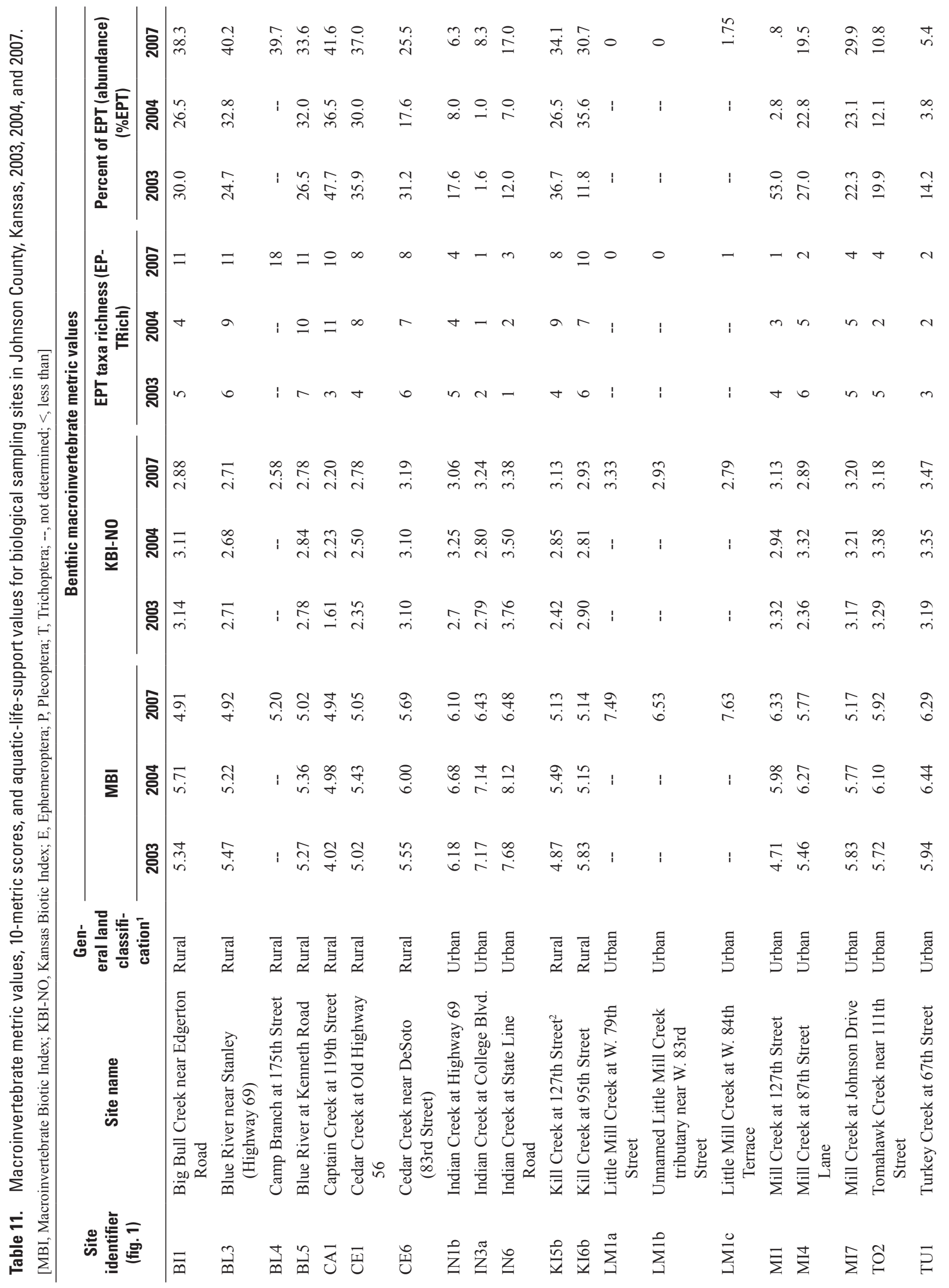




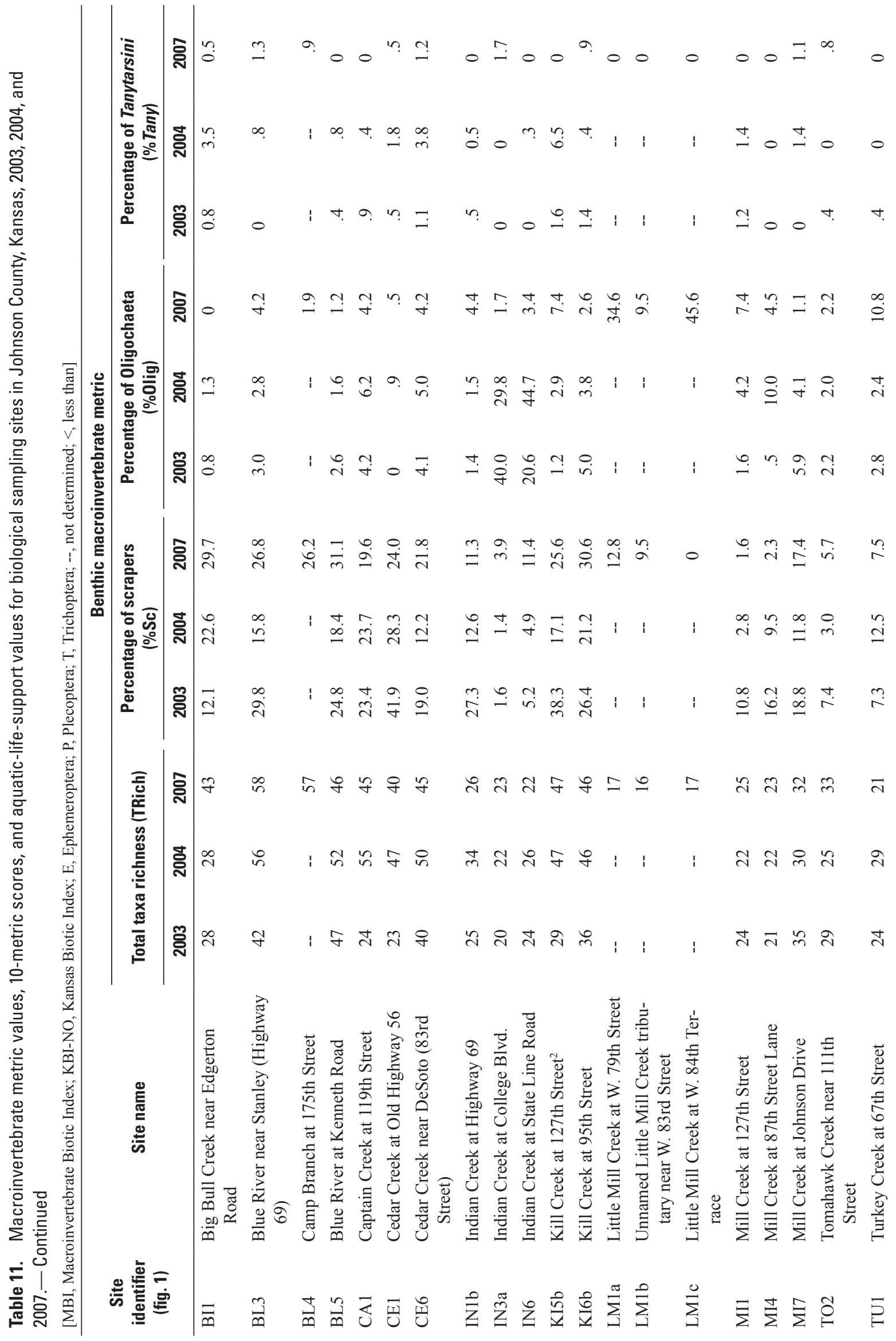




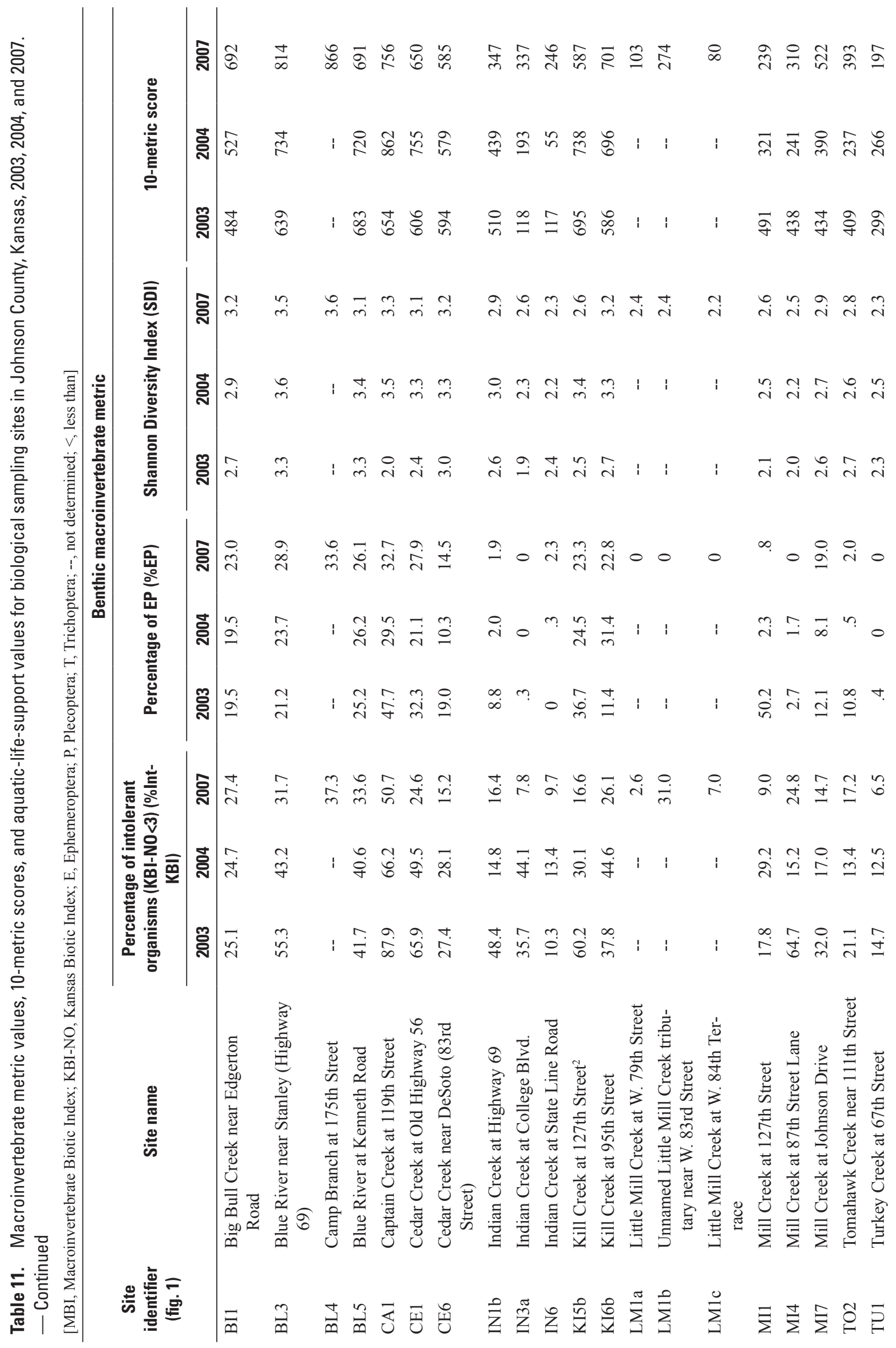




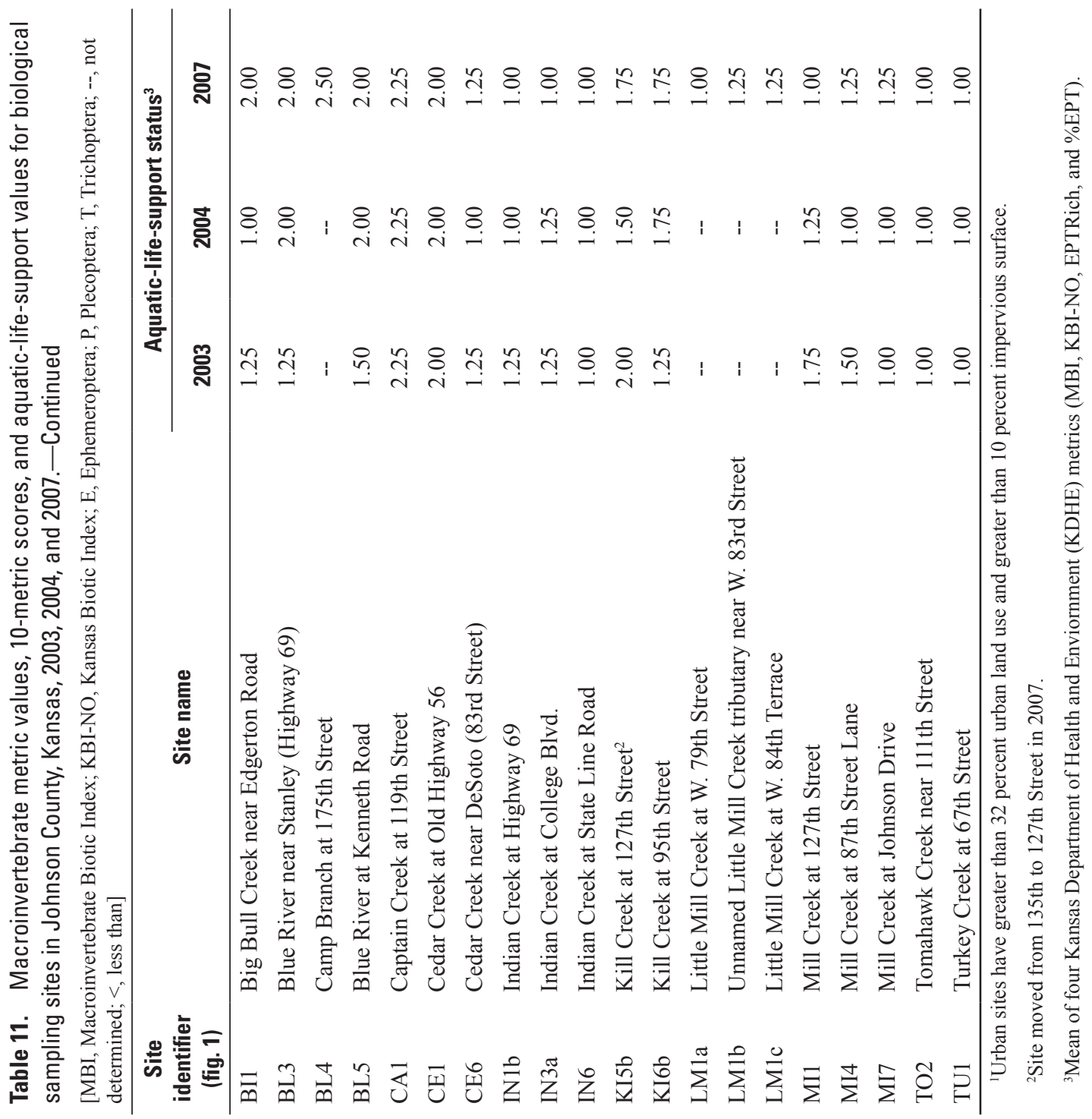





\section{Appendices 1-7}




\section{Habitat assessment protocol used during evaluation of stream quality in Johnson County, Kansas, 2007}

Most habitat assessment protocols, including the one used in this study, contain a synthesis of specific ecological measurements (variables) that can be rated or scored across a range of conditions that represent relative levels of quality (optimal or excellent, suboptimal or good, marginal or fair, and poor). The USEPA's Rapid Habitat Assessment Protocol (Barbour and others, 1999) is the foundation for most of the variables included in this protocol. Some of the variables were modified to provide more meaningful information about both urban and rural streams in this geographic region and to better differentiate among sites. Variables were directly measured, visually estimated, or determined from examination of specific physical features. The scale at which these variables may affect aquatic biota varies, and therefore, some variables were measured at the reach or segment scale. Habitat-quality evaluations that are systematically conducted generally have the following goals: (1) identification of specific causes or sources of stream degradation or impairment, (2) determination of whether habitat conditions may or may not potentially be a cause of poor water quality or biological impairment, (3) establishment of baseline habitat characterization for monitoring future stream changes, (4) use of a consistent approach to determine a range in habitat conditions among numerous study sites, and (5) identification of the strength of statistical relations between habitat, water, and biological quality.

This assessment protocol integrates data for three habitat categories - channel, stream/bank/riparian, and in-stream aquatic. Variables measured in the channel category include indicators of overall channel morphology such as channel slope and sinuosity. Parameters included in the stream bank/ riparian category provide information on organic matter sources, bank conditions, and the degree of disturbance in the riparian zone. Variables in the in-stream aquatic category provide information on the availability of cover and substrate materials, and the stream's capacity for meeting basic physical requirements for support of a diverse and well-balanced aquatic community.

Data were evaluated at two hierarchical scales (stream segment and stream reach) using a classification system proposed by Frissell and others (1986) and slightly modified by the National Water Quality Assessment (NAWQA) Program (Fitzpatrick and others, 1998). Segment-scale data also were obtained from geographic information system (GIS) coverages, topographic maps, and aerial photographs. A stream segment is defined as a section of stream that is relatively homogeneous with respect to physical, chemical, and biological properties and generally bounded by tributary junctions, point-source discharges, or other features that might be expected to change stream properties (Fitzpatrick and others, 1998). The upstream boundary of the segment was defined by a change in stream order or presence of wastewater discharge. The downstream boundary of the segment was defined as 50 meters $(\mathrm{m})$ downstream from the downgradient boundary of the reach. The segment extended a small distance downstream from the reach to include stream features that might possibly affect quality such as backwater and point discharges into slow-moving pools. Stream segment lengths at Johnson County biological sampling stream sites ranged from less than $1 \mathrm{mi}$ for two of the Little Mill Creek sites (LM1b and LM1c) to about $14 \mathrm{mi}$ for the Captain Creek site (CA1). Reach-scale data were collected during site visits. The reach is a section of the stream where a water and biological sampling site exists and included at least two riffle-pool sequences as an indication of representative habitat diversity. Each reach was a minimum of $450 \mathrm{ft}$. and not more than $900 \mathrm{ft}$. in length. If there were not two riffle-pool sequences, the reach included partial pool sections upstream and downstream from the riffle that was used for biological sampling. Stream reaches in Johnson County ranged from $475 \mathrm{ft}$. at one of the Little Mill Creek sites (LM1a) to $900 \mathrm{ft}$. at the downstream Mill Creek site (MI7).

\section{Channel Characteristics}

Channel characteristics are indicators of channel condition that may have direct or indirect effects on aquatic biota and are related to stream morphology and hydrology.

\section{Flow Status}

Flow status (Barbour and others, 1999) is a reach-scale variable that indicates the extent of streambanks and substrate materials exposed during base-flow conditions. When water does not cover much of the streambed, the amount of suitable substrate for aquatic organisms is reduced. The flow status changes as the channel changes (during aggradation of the stream bed, for example) or as flow decreases or increases (as a result of irrigation diversion, drought, or municipal discharge, for example). Flow status is most useful for interpreting biological condition under abnormal or smaller flow conditions. Optimal flow-status conditions for biota exist when water reaches the base of both streambanks and a minimal amount of channel substrate is exposed. Conditions are poor when very little water is present in the channel and water occurrs mostly as standing pools.

\section{Channel Slope and Morphological Status}

Channel slope and morphological status is a reach-scale measurement of the slope of streambanks in relation to the channel and channel shape ( $\mathrm{V}$ or $\mathrm{U}$ shaped). This variable is an indicator of the degree of incision, downcutting, or headcutting that has occurred in the channel. Downcutting and lateral cutting can impair function because of increased scour and downstream sediment transport. Downcutting channels frequently have changes in the elevation of the stream bottom 
and steeper angles between the bottom of the channel and the top of the streambanks. Bank slope was measured using clinometer readings and visual estimation at 10 evenly spaced points along the reach length for right and left (determined by looking downstream) streambanks. Percentage slope measurements were made at each transect from the middle of the channel.

Morphological status is one of the more difficult variables to interpret because the degree of channel incision that is present in a stream may be dictated by the stream size, type, geology, and ecoregional characteristics (Harrelson and others, 1994). Incision may have occurred recently or gradually over many years or decades. In some instances, bank and riparian conditions are more protected from erosion, and the process is slowed. Morphological status might usually be scored on the basis of the assumption that a steeper bank-slope angle is an indicator that channel incision is more active or recent. Because sites in Johnson County represent a range of stream sizes, the percentage difference in elevation between opposing banks is also considered in the score rather than relying only on the degree of bank slope itself. The difference, expressed as the mean percentage difference in slope between right and left banks for the entire reach, is an indicator of the potential for flood-plain interaction during flooding. Flood-plain interaction may provide more protection for aquatic organisms during floods. Flood-plain interaction also may provide an increase in organic matter inputs. The difference in elevation between opposing streambanks, such as occurs along bends in many types of streams, may indicate a high likelihood for flood-plain interaction. Therefore, this variable is scored on the basis of the assumption that when channel slopes are nearly the same on both sides of the stream, flood-plain interactions are less likely to occur, may require floods of larger magnitude, or may occur with less frequency.

The site score for percentage difference in elevation of opposing streambanks took into account the slope values for both right and left bank (in degrees), percentage difference in bank slope, and the predominant cross-sectional shape of the stream bottom across all 10 transects. Conditions are considered optimal when bank elevations are near the elevation of the active flood plain, the channel cross-section is V- or U-shaped, there is little evidence of lateral or downcutting, the mean bank slope is less than 15 percent, and the mean difference between right and left bank slopes is greater than 5 percent. Poor conditions existed when banks are much higher than the elevation of the active flood plain, the channel is trapezoid-shaped, mean bank slope is greater than 35 percent, and the mean difference between right and left bank slopes is less than 2 percent.

\section{Sinuosity}

Sinuosity (Barbour and others, 1999) is a segment-scale measure that describes the meandering of the stream. It is the ratio of the channel length to the valley centerline length (Schumm, 1963) and can be obtained from aerial photographs and topographic maps. Streams that are more sinuous provide diverse habitat and fauna, and a stream is better able to handle flow surges when streamflow fluctuates as a result of runoff. The absorption of this energy by bends and repeated channel cross-over and bend sequences protects the stream from excessive erosion and flooding and provides a refuge for benthic invertebrates and fish during storms. Conditions for sinuosity are considered optimal when the bends in the stream increase the stream length three to four times compared to a straight line. Conditions are poorest if the channel is straight as a result of channelization.

\section{Pool Status}

Pool status (Natural Resources Conservation Service, 1998) provides an indication of pool abundance and mix of deep and shallow pools that are present. Pool status is visually estimated considering the entire reach. Pools are important resting and feeding sites for fish, and pool margins provide standing-water habitats for macroinvertebrates. A healthy stream has a mix of shallow and deep pools. A deep pool is 1.6 to 2.0 times deeper than the mean reach depth, whereas a shallow pool is less than 1.5 times deeper than the mean reach depth. Pools are considered abundant if a deep pool occurs in each of the meander bends in the reach being assessed. Pool diversity and abundance are estimated by walking the stream or probing from the streambank with a stick. Deep pools are located on the outside of meander bends. Conditions are considered optimal if both deep and shallow pools exist in the reach and more than 30 percent of the pool bottoms are obscured because of depth. Poor conditions exist if there are no pools and the entire streambed is visible.

\section{Riffle Frequency}

Riffle frequency is a measure of the number of riffles in the stream segment and is obtained from aerial photographs or topographic maps. Riffles are a source of high-quality habitat and a diverse fauna; therefore, an increased frequency of riffles greatly enhances the diversity of the stream community (Barbour and others, 1999). Streams with more frequent, longer riffles tend to provide more available surface area of epifaunal substrate in comparison to streams dominated by long pools. In certain types of streams riffle occurrence may not be readily apparent because channel constrictions, exposed gravel bars, bluffs, or other channel features that may indicate riffle presence are not visible from maps or aerial photographas. Riffle frequency also is related to a decline in surface-water elevation, and this may provide an indication of riffle frequency for types of streams where other riffle/pool sequence indicators cannot be determined from maps and aerial photographs. Streams with infrequent riffles usually have more gradual changes in elevation.

Riffle frequency is scored on the basis of a combination of the number of riffles observed in the reach and the longi- 
tudinal decline in water elevation throughout the segment. Elevations are determined from 2-ft contour maps provided by the Johnson County Automated Information Mapping System (AIMS). Conditions are considered optimal when elevation declines at least $26 \mathrm{ft} / \mathrm{mi}(5$ meters per kilometer $(\mathrm{m} / \mathrm{km}))$ and at least four riffles occur within the reach. Conditions are poor if the elevation decrease is less than about $5 \mathrm{ft} / \mathrm{mi}(1 \mathrm{~m} / \mathrm{km})$ and only one shallow riffle occurs.

\section{Streambank and Riparian Characteristics}

Bank and riparian characteristics provide information on stream energy sources, degree of disturbance in the riparian zone, and the potential for streambank erosion. Bank and riparian characteristics measured in this study include bank stability, canopy cover, bank and riparian protection, and length, extent, and width of buffers.

\section{Bank Stability}

Bank stability (Barbour and others, 1999) is a reach-scale measure of whether the stream-banks are eroded or have the potential for erosion during periods of increased streamflow. It is a visual estimation of the percentage of the bank area that is stable (not eroding or sloughing) and included vegetation, natural bedrock outcroppings, and the roots of woody vegetation that stabilize the bank soils or deflect high flows during storms. The right bank and left bank are evaluated separately. Steep unvegetative banks are generally more likely to collapse and suffer from erosion than are gently sloping banks. Signs of erosion include crumbling, unvegetated banks, exposed tree roots, and exposed soil. Eroded banks may indicate a problem of sediment movement and deposition, and also can indicate a scarcity of cover and organic input to streams.

Bank stability is determined by averaging a series of visual estimations made at 10 evenly spaced points in the stream throughout the reach. Each bank is evaluated separately and the mean (right and left banks) is calculated. Bank conditions are considered optimal when banks appear stable throughout the reach, less than 5 percent of the banks show evidence of erosion, and more than one-third of the erodible banks on outside bends is protected by roots or vegetation. Conditions are poor when 60 to 100 percent of banks have erosional scars.

\section{Canopy Cover}

Canopy cover (Natural Resources Conservation Service, 1998) is a measure of the percentage of the reach that is shaded by overhanging vegetation and other features in the stream channel. Stream shading is important because it decreases light availability and helps to keep water temperatures cool, which limits excessive algae and vegetation growth. However, fully shaded streams may limit primary production to the extent that it may affect the presence of grazing macroinvertebrates and the stream's ability to attenuate levels of excess nutrients. For the warm-water streams evaluated using this protocol, canopy cover is scored on the basis of the assumption that streams support a healthy and more diverse aquatic biota when there is partial shade as compared to those exposed to full shade or full sunlight.

Canopy cover is estimated using a densiometer and visual judgement from the center of the stream at 10 evenly spaced points along the reach and then averaged. The relative amount of shade is estimated by assuming that the sun is directly overhead and the vegetation is in full leaf. Conditions are considered optimal when 50 to 80 percent of the reach is shaded and poor when less than 10 or more than 90 percent is shaded.

\section{Bank and Riparian Protection}

Bank and riparian protection (Barbour and others, 1999) is a measure of the percentage of the bank surface area within the reach that is covered with natural materials such as vegetation, rock, or bedrock outcroppings. Percentage of coverage is estimated visually for the left bank and right bank from 10 evenly spaced points and then averaged. Artificial materials such as riprap or concrete are not included in the estimate. This measure provides an indication of how well the streambank and the near-stream portion of the riparian zone resist erosion, uptake nutrients, and control in-stream scouring.

\section{Length and Extent of Buffers}

Length and extent of buffers provide an estimate of both the extent of buffers and the number of gaps in longitudinal continuity. This variable takes into account the buffers within the reach and segment and is obtained from onsite observations and aerial photographs. Buffers are defined as land covered with natural vegetation that could include forest, shrubs, or grasses. The extent of drainage connectivity and the mean length of fully buffered sections upstream from a particular stream site have been identified as important segment-scale measurements for evaluating the quality of urban streams (Walsh and others, 2005b). The longitudinal continuity of buffers is related to the number of bridge crossings and stormwater drains entering the stream and the extent of areas cleared for construction and development. In areas where these activities are common, there are more frequent opportunities for stormwater to enter the stream directly without passing through vegetated soils. An increase in direct stormwater drainage connections also can affect the intensity and magnitude of flooding. Conditions are considered optimal when the mean longitudinal length of buffers that are at least $20 \mathrm{ft}(6 \mathrm{~m})$ wide within the segment is larger than about 2,500 $\mathrm{ft}(750 \mathrm{~m})$ and extends along at least 90 percent of both banks. Conditions are poor when the mean longitudinal length of buffers in less than $820 \mathrm{ft}(250 \mathrm{~m})$ and encompasses less than 70 percent along both banks. 


\section{Mean Buffer Width}

Mean buffer width (Barbour and others, 1999) is a reachscale measurement of the mean width of natural vegetation (including forest, shrubs, or grasses) from the edge of the streambank out through the riparian zone. The vegetative zone serves as a buffer to pollutants entering a stream from runoff, as a control of erosion, and as inputs of nutrients and organic matter into the stream. A wider buffer allows runoff more time to percolate into soils or be filtered by vegetation before entering the stream. Wider, more vegetated, and less-disturbed riparian zones also produce more organic matter that provides a constant supply of energy to the stream. Buffer width is estimated visually for the left bank and right bank separately at 10 evenly spaced points in the stream over the length of the reach. Conditions are considered optimal when the mean buffer width is larger than about $60 \mathrm{ft}(18 \mathrm{~m})$ on both banks. Conditions are poor when the mean buffer width is less than $20 \mathrm{ft}(6 \mathrm{~m})$. Pedestrian and biking trails in the buffer zone are considered to be inconsequential and do not affect bufferwidth estimates.

\section{Percentage of Altered Banks}

The percentage of bank and above-bank riparian zones that have been altered physically can provide an indication of large-scale changes in the shape of the stream channel. Alterations along the banks may reduce organic matter inputs or hydrologic diversity. Alterations include channelization, concrete, levees, dikes, piers, riprap, impoundments, bridges, and in-stream activities such as clearing, operation of heavy equipment, and bridge construction. Streams that have been straightened, deepened, or converted to concrete channels have far fewer natural habitats for fish, macroinvertebrates, and plants than do naturally meandering streams (Barbour and others, 1999). Some older modifications that have become overgrown with native vegetation may not score as poorly as recently altered areas. Percentage of altered banks is estimated at 10 points along each bank of the reach. Conditions are optimal when none of the alteration activities are occurring in the reach and past human activities affect less than 10 percent of the total bank and buffer area. Conditions are poor when more than three activities or features are present or more than 70 percent of the bank and buffer area is affected by human activities.

\section{In-Stream Habitat Characteristics}

Habitat characteristics that are located within the stream channel itself provide information about in-stream cover and aquatic habitat that are directly available as living space for aquatic organisms. These features, all measured at the reach scale, relate to the ability of the stream to meet basic physical requirements for supporting diverse and well-balanced aquatic communities.

\section{Riffle Substrate Fouling}

Riffle substrate fouling is an estimate of the amount of periphyton growth and accumulation of fine materials that are covering the substrate materials in riffles. It is visually estimated for the length of the reach by examining several locations where the bottom substrate is visible. Excessive amounts of periphyton growth trap fine particulates and can cause the clogging of interstitial spaces in gravel and cobble substrates, often leading to greater substrate embeddedness and a decline in overall living space for macroinvertebrates and riffle-dwelling fishes. Riffle substrate fouling is also directly related to larger sediment loads during rainfall, extent of bank erosion, and the turnover of periphyton growth, because these characteristics represent the direct sources for finer substrate particles that may be deposited in riffle areas. Conditions are optimal when visible periphyton and fine materials affect less than 10 percent of the substrate and very little sloughing occurrs when substrate is physically disturbed. Poor conditions exist when more than 60 percent of the substrate is covered with periphyton and fine materials and extensive cloudiness occurrs when substrate is disturbed.

\section{Velocity/Depth Combinations}

Patterns of velocity and depth (Barbour and others, 1999) are related to habitat diversity. Streams with at least four patterns of velocity and depth-- slow-shallow, slow-deep, fast-shallow, and fast-deep-- generally have the most diversity. This is a reach-scale measurement that is estimated visually. Optimal conditions exist when all four combinations are present, and poor conditions exist when only one is present.

\section{Riffle Substrate Embeddedness}

Riffle substrate embeddedness (Barbour and others, 1999 ) is a measure of the percentage of rock and snag substrates in riffles that are surrounded by or sunken into finer materials. Generally, as rocks become embedded, the surface area and living space available to macroinvertebrates and fish (for shelter, spawning, egg incubation) decrease. Riffle substrate embeddedness is evaluated by hand removal of 20 randomly chosen cobblestones across riffle transects within the reach, estimating the depth of the cobble in fine material as a percentage of total depth, and averaging the 20 values. Conditions are optimal when mean cobble depth in fine materials is less than 20 percent of total fine-material depth and poor when cobble depth is more than 75 percent of total depth.

\section{Sediment Deposition}

Sediment deposition (Barbour and others, 1999) provides an estimate of the amount of sediment that has accumulated in pools and other changes that have occurred to the stream bottom as a result of deposition. Sediment deposition may form 
islands and point bars and fill runs and pools. Usually deposition occurs in areas that are obstructed by natural or manmade debris and areas where the streamflow decreases, such as the inside portion of meander bends or along the edges of small backwater inlets. Large amounts of sediment deposition may indicate a continually changing environment unsuitable for many organisms. Sediment deposition is visually estimated for the entire reach. Conditions are considered optimal when less than 20 percent of the stream bottom is affected by deposition and little or no island or point-bar deposition is visible. Conditions are poor when thick sediment deposits are visible, more than 80 percent of the stream changes frequently, and fresh deposits occur along major portions of the overbank areas.

\section{Diversity of Epifaunal Substrate and Cover}

Diversity of epifaunal substrate and cover (Barbour and others, 1999) is a measure of the number and variety of instream habitat and cover types. This includes natural structures in the stream such as leaf packs, anchored woody debris, root mats, overhanging or inundated vegetation, organic debris accumulation, undercut banks, submerged macrophyte beds, and isolated backwater. These features provide protection, feeding sites, sites available for colonization by grazers and clingers, emergence sites, and sites for spawning. For optimum conditions, these features are fairly stable. A wide variety and abundance of good habitat increase overall biotic diversity in the reach. As variety and abundance of habitat decrease, diversity decreases, and the potential for recovery following disturbance declines. Snags and submerged logs are among the most productive habitat structures for macroinvertebrate colonization, particularly if they have been submerged for a long period of time.

Diversity of epifaunal substrate and cover is visually estimated for the stream reach. Optimal conditions exist when at least seven habitat/cover types are present and at least 70 percent are stable and available for aquatic colonization. Poor conditions exist when one or none of the cover types are present and less than 20 percent are stable or available for colonization.

\section{Riffle Substrate Composition}

Riffle substrate composition is a measure of the percentage of cobble, gravel, and finer materials in riffles. Cobble and boulders are mineral materials larger than 64 millimeter $(\mathrm{mm})$, gravel and pebble materials are 2 to $64 \mathrm{~mm}$, and finer materials (including sand, silt, and clay) are less than $2 \mathrm{~mm}$. The cobble, gravel, and fine materials of riffle substrates are important for macroinvertebrate colonization because they provide stability, surface area, and interstitial living space. These measurements are made at 20 randomly selected locations in riffles. Percentages are visually estimated with a sheet of plexiglass that is placed onto the water surface to remove glare, thereby enhancing visibility of the stream bottom. Conditions are optimal when the larger substrate classes (cobble and boulder) make up more than 50 percent of the bottom surface and less than 10 percent of the bottom consists of finer substrate sizes (less than $2 \mathrm{~mm}$ ). Conditions are poor when there is less than 5 percent cobble and sand and silt make up more than 50 percent of the substrate. 


\section{Stream Habitat Assessment Sheet}

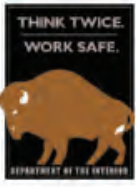

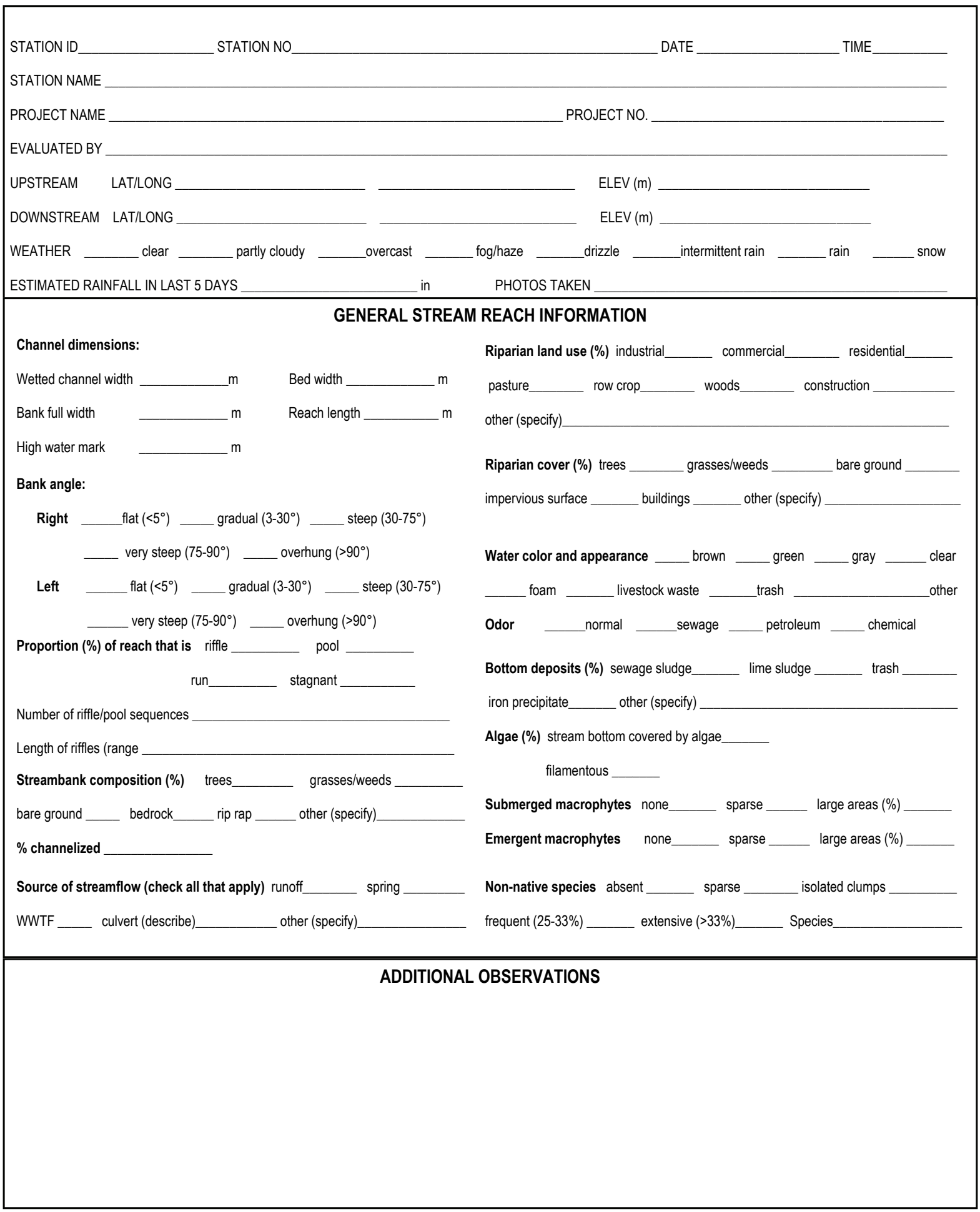


Category $1-$ Channel Conditions and Characteristics

\begin{tabular}{|c|c|c|c|c|c|c|c|c|c|c|c|c|}
\hline \multirow{3}{*}{ A. Flow Status (reach) } & \multicolumn{3}{|c|}{ Optimal } & \multicolumn{3}{|c|}{ Suboptimal } & \multicolumn{3}{|c|}{ Marginal } & \multicolumn{3}{|c|}{ Poor } \\
\hline & \multicolumn{3}{|c|}{$\begin{array}{l}\text { Water reaches base of both lower } \\
\text { banks, and minimal amount of } \\
\text { channel substrate is exposed. }\end{array}$} & \multicolumn{3}{|c|}{$\begin{array}{l}\text { Water fills }>75 \% \text { of the available } \\
\text { channel; or }<25 \% \text { of channel is } \\
\text { substrate exposed. }\end{array}$} & \multicolumn{3}{|c|}{$\begin{array}{l}\text { Water fills } 25-75 \% \text { of the available } \\
\text { channel, and/or riffle substrates are } \\
\text { mostly exposed. }\end{array}$} & \multicolumn{3}{|c|}{$\begin{array}{l}\text { Very little water in channel and } \\
\text { mostly present as standing pools. }\end{array}$} \\
\hline & 12 & 11 & 10 & 9 & 8 & 7 & 6 & 5 & 4 & 3 & 2 & 1 \\
\hline \multirow{6}{*}{$\begin{array}{l}\text { B. Channel Slope and } \\
\text { Morphological Status } \\
\text { (reach) }\end{array}$} & \multirow{3}{*}{$\begin{array}{l}\text { Average } \\
\text { Percent }\end{array}$} & & 1 & 2 & 3 & 4 & 5 & 6 & 7 & 8 & 9 & 10 \\
\hline & & Left Bank & & & & & & & & & & \\
\hline & & Right Bank & & & & & & & & & & \\
\hline & - & Bank shape & & & & & & & & & & \\
\hline & \multicolumn{3}{|c|}{$\begin{array}{l}\text { Banks are low at elevation of active } \\
\text { flood plain (slope }<20 \%) \text {. Channel } \\
\text { cross sectional shape is a } \\
\mathrm{V} \text { or } \mathrm{U} \text {, and there is no evidence of } \\
\text { lateral or downcutting. Mean slope of } \\
\text { reach (both banks considered) is } \\
<15 \% \text { and average } \% \text { difference in } \\
\text { slopes between right and left banks } \\
\text { is }>5.0 \%\end{array}$} & \multicolumn{3}{|c|}{$\begin{array}{l}\text { Banks are a moderate height at } \\
\text { elevation of active flood plain } \\
\text { (slope 20-45\%). Channel cross } \\
\text { sectional shape is a U, and there is } \\
\text { some evidence of lateral or } \\
\text { downcutting. Mean slope of reach } \\
\text { (both banks considered) is } 15-24.9 \% \\
\text { and average \% difference in slopes } \\
\text { between right and left banks is 3.5- } \\
5.0 \%\end{array}$} & \multicolumn{3}{|c|}{$\begin{array}{l}\text { Banks are high at elevation of active } \\
\text { flood plain (slope } 45-60 \% \text { ). Channel } \\
\text { cross sectional shape is a U or trape- } \\
\text { zoid with steeper sides, and there is } \\
\text { some evidence of lateral or downcut- } \\
\text { ting. Mean slope of reach (both banks } \\
\text { considered) is } 25-34.9 \% \text { and average } \% \\
\text { difference in slopes between right and } \\
\text { left banks is 2.0-3.49\% }\end{array}$} & \multicolumn{3}{|c|}{$\begin{array}{l}\text { Banks are high at elevation of } \\
\text { active flood plain (slope }>60 \%) \text {. } \\
\text { Channel cross sectional shape is a } \\
\text { trapezoid with steep sides, and } \\
\text { there is considerable evidence of } \\
\text { lateral or downcutting. Mean slope } \\
\text { of reach (both banks considered) is } \\
>35 \% \text { and average \% difference in } \\
\text { slopes between right and left banks } \\
\text { is }<2.0 \%\end{array}$} \\
\hline & 12 & 11 & 10 & 9 & 8 & 7 & 6 & 5 & 4 & 3 & 2 & 1 \\
\hline C. Sinuosity (segment) & \multicolumn{3}{|c|}{$\begin{array}{l}\text { The bends in the stream increase the } \\
\text { stream length } 3 \text { to } 4 \text { times longer } \\
\text { than if it was in a straight line. (note- } \\
\text { channel braiding is considered } \\
\text { normal in coastal plains and other } \\
\text { low-lying areas. This parameter is not } \\
\text { easily rated in these areas. }>2.50 \\
12 \quad 11 \quad 10\end{array}$} & \multicolumn{3}{|c|}{$\begin{array}{l}\text { The bends in the stream increase the } \\
\text { stream length } 2 \text { to } 3 \text { times longer } \\
\text { than if it was in a straight line. } \\
\qquad 1.75-2.49\end{array}$} & \multicolumn{3}{|c|}{$\begin{array}{l}\text { The bends in the stream increase } \\
\text { the stream length } 1 \text { to } 2 \text { times } \\
\text { longer than if it was in a straight } \\
\text { line. } \quad 1.25-1.74\end{array}$} & \multicolumn{3}{|c|}{$\begin{array}{l}\text { Channel straight; waterway has } \\
\text { been channelized for a long dis- } \\
\text { tance. } \\
\qquad<1.25\end{array}$} \\
\hline \multirow[t]{2}{*}{ D. Pool Status (reach) } & \multicolumn{3}{|c|}{$\begin{array}{l}\text { Mix of deep and shallow pools } \\
\text { abundant; greater than } 30 \% \text { of the } \\
\text { pool bottom is obscure due to depth, } \\
\text { or the pools are at least } 5 \text { feet deep. }\end{array}$} & \multicolumn{3}{|c|}{$\begin{array}{l}\text { Pools present, but not abundant; } \\
\text { from } 10 \text { to } 30 \% \text { of the pool bottom is } \\
\text { obscure due to depth, or the pools } \\
\text { are at least } 3 \text { feet deep. }\end{array}$} & \multicolumn{3}{|c|}{$\begin{array}{l}\text { Pools present, but shallow; from } 5 \\
\text { to } 10 \% \text { of the pool bottom is ob- } \\
\text { scure due to depth, or the pools are } \\
\text { less than } 3 \text { feet deep. }\end{array}$} & \multicolumn{3}{|c|}{$\begin{array}{l}\text { Pools absent, or the entire bottom } \\
\text { is discernible. }\end{array}$} \\
\hline & 12 & 11 & 10 & 9 & 8 & 7 & 6 & 5 & 4 & 3 & 2 & 1 \\
\hline \multirow[t]{2}{*}{$\begin{array}{l}\text { E. Riffle Frequency } \\
\text { (segment) }\end{array}$} & \multirow{2}{*}{\multicolumn{3}{|c|}{$\begin{array}{l}\text { Occurrence of riffles relatively fre- } \\
\text { quent; variety of habitata is key. In } \\
\text { streams where riffles are continuous, } \\
\text { placement of boulders or other large } \\
\text { natural obstruction is important. } \\
>5 \mathrm{~m} \text { drop per } \mathrm{km} \text { and at least } 4 \\
\text { riffles visible within the reach } \\
12 \\
11\end{array}$}} & \multicolumn{3}{|c|}{$\begin{array}{l}\text { Occurrence of riffles infrequent. } \\
\qquad \begin{array}{l}2.5-4.9 \mathrm{~m} \text { drop per km } \\
\text { and } 3 \text { riffles visible in reach }\end{array}\end{array}$} & \multicolumn{3}{|c|}{$\begin{array}{l}\text { Occasional riffle or bend; bottom } \\
\text { contours provide some habitat. } \\
1.0-2.49 \mathrm{~m} \text { drop per } \mathrm{km} \\
\text { And } 2 \text { riffles visible in reach }\end{array}$} & \multicolumn{3}{|c|}{$\begin{array}{l}\text { Generally all flat water or shallow } \\
\text { riffles; poor habitat. } \\
\quad<1.0 \mathrm{~m} \text { drop per km } \\
\text { and } 1 \text { riffle visible in reach }\end{array}$} \\
\hline & & & & 9 & 8 & 7 & 6 & 5 & 4 & 3 & 2 & 1 \\
\hline
\end{tabular}

Category 2-Bank and Riparian Conditions

\begin{tabular}{|c|c|c|c|c|c|c|c|c|c|c|c|c|}
\hline \multirow{6}{*}{ A. Bank Stability (reach) } & \multicolumn{3}{|c|}{ Optimal } & \multicolumn{3}{|c|}{ Suboptimal } & \multicolumn{3}{|c|}{ Marginal } & \multicolumn{3}{|c|}{ Poor } \\
\hline & \multirow{2}{*}{ Average } & & 1 & 2 & 3 & 4 & 5 & 6 & 7 & 8 & 9 & 10 \\
\hline & & \multicolumn{11}{|l|}{ Left bank } \\
\hline & \multicolumn{3}{|c|}{ Right bank } & & & & & & & & & \\
\hline & \multicolumn{3}{|c|}{$\begin{array}{l}\text { Banks are stable throughout reach. } \\
\text { Evidence of erosion/sloughing or bank } \\
\text { failure absent or minimal (<5\% af- } \\
\text { fected). } 33 \% \text { or more of the eroding } \\
\text { surface area of banks on outside } \\
\text { bends is protected by roots that } \\
\text { extend to the base flow elevation. }\end{array}$} & \multicolumn{3}{|c|}{$\begin{array}{l}\text { Banks are moderately stable } \\
\text { throughout reach. Infrequent, } \\
\text { small areas of erosion/sloughing } \\
\text { mostly healed over. } 5-30 \% \text { of } \\
\text { bank in reach has erosion areas. } \\
\text { Less than } 33 \% \text { of the eroding } \\
\text { surface area of banks on outside } \\
\text { bends is protected by roots that } \\
\text { extend to the base flow elevation. }\end{array}$} & \multicolumn{3}{|c|}{$\begin{array}{l}\text { Banks are moderately unstable } \\
\text { throughout reach. Evidence of } \\
\text { erosion/sloughing or bank failure } \\
\text { obvious; } 30-60 \% \text { of bank in reach } \\
\text { has areas of erosion. High erosion } \\
\text { potential during floods. }\end{array}$} & \multicolumn{3}{|c|}{$\begin{array}{l}\text { Banks are unstable, with many } \\
\text { eroded (raw) areas frequent along } \\
\text { straight sections and bends. } 60- \\
100 \% \text { of banks have erosional } \\
\text { scars. High erosion potential } \\
\text { during floods. }\end{array}$} \\
\hline & 12 & 11 & 10 & 9 & 8 & 7 & 6 & 5 & 4 & 3 & 2 & 1 \\
\hline
\end{tabular}


Category 2-Bank and Riparian Conditions (cont.)

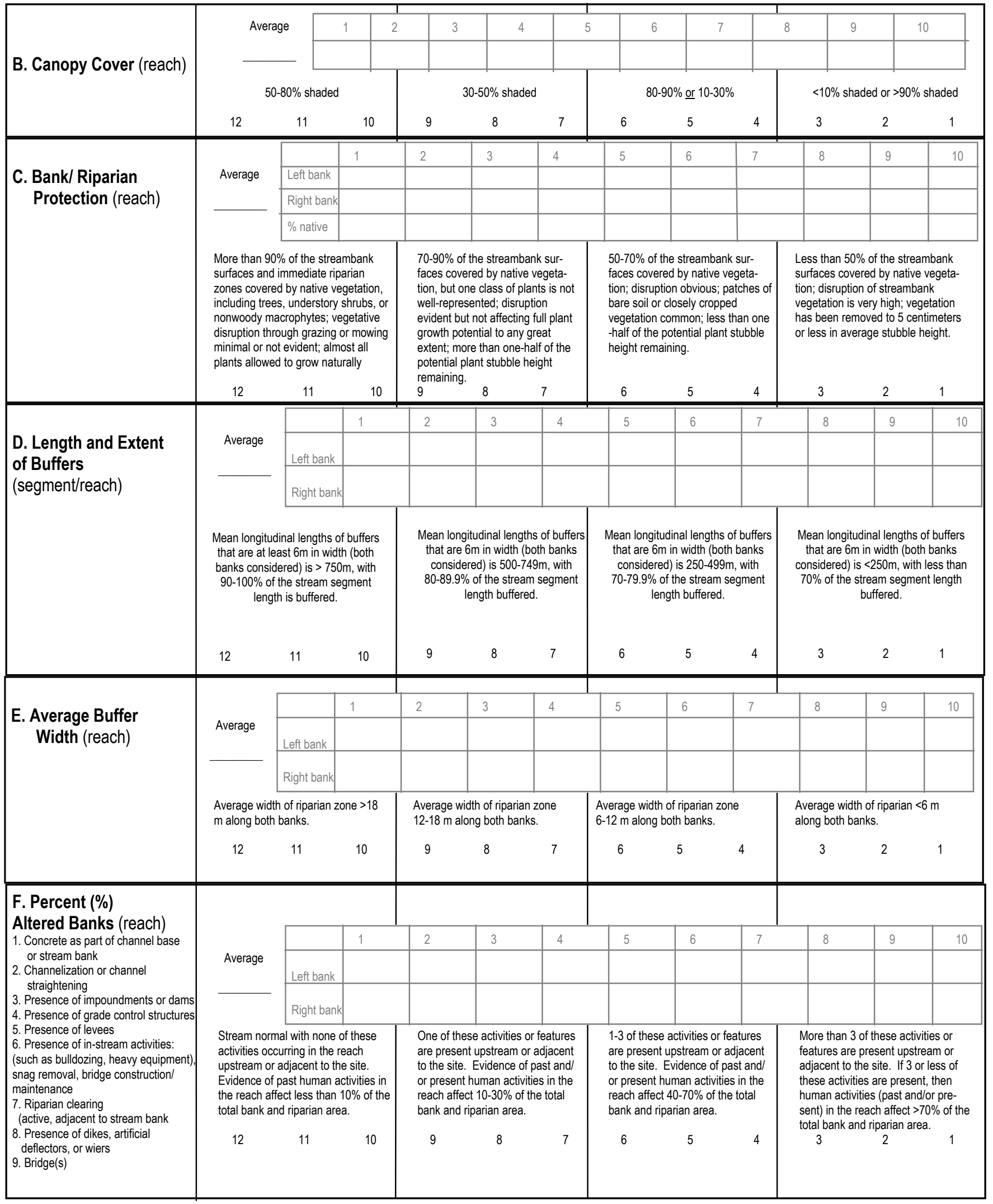


Category 3-Aquatic Habitat Availability

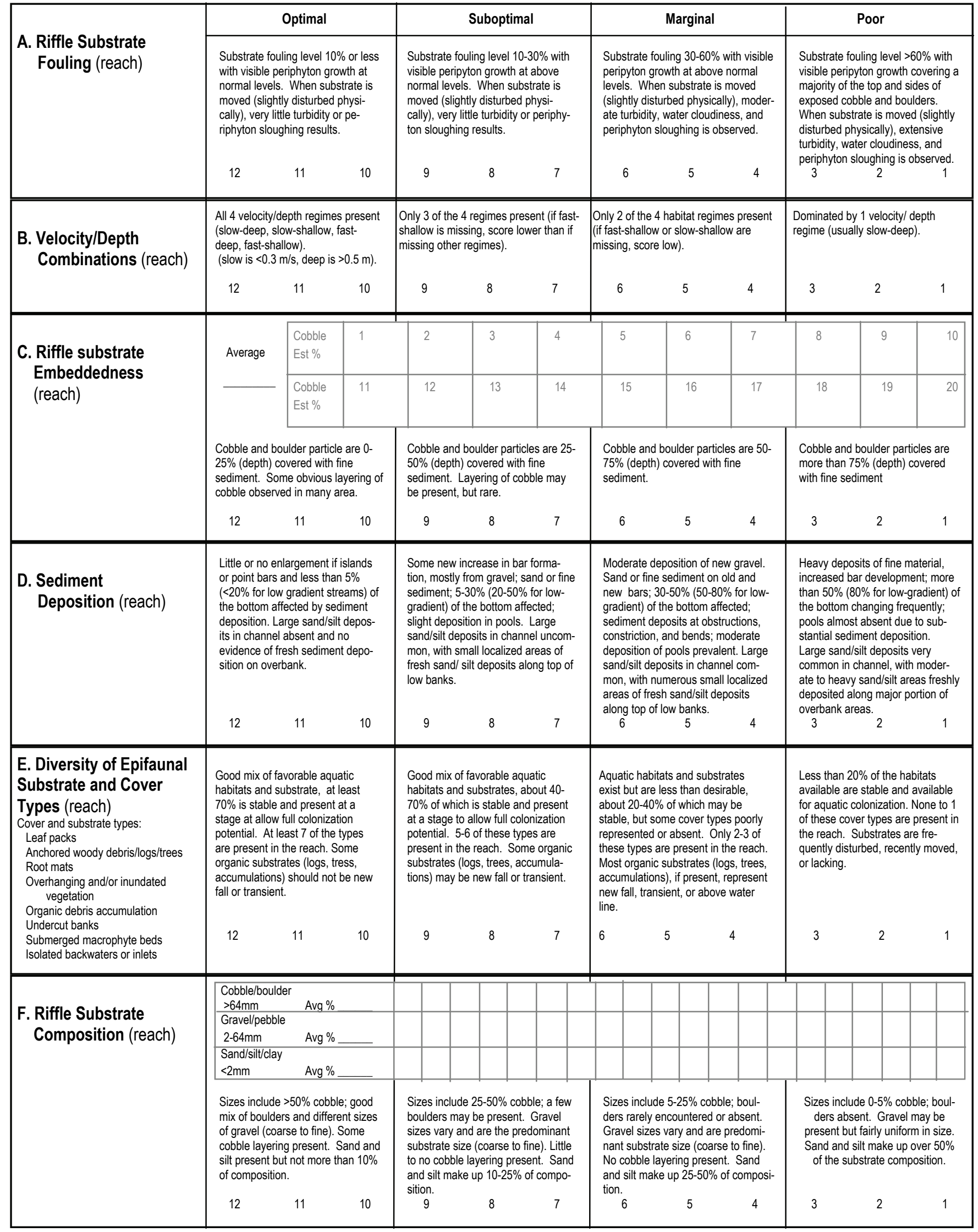


Appendix 2. Periphyton taxa identified and the number of biological sampling sites where each taxa occurred in Johnson County, Kansas, streams during March and July 2007.

[Bacillariophyta, diatoms; Chlorophyta, green algae; Cyanophyta, blue-green algae or cyanobacteria; Euglenophyta, euglenoids; --, taxa did not occur]

\begin{tabular}{|c|c|c|c|}
\hline \multirow{2}{*}{ Division } & \multirow{2}{*}{ Taxa } & \multicolumn{2}{|c|}{ Site number } \\
\hline & & March & July \\
\hline \multirow{47}{*}{ Bacillariophyta } & Achnanthes exigua & 3 & 7 \\
\hline & Actinocyclus normanii & -- & 1 \\
\hline & Amphora inariensis & 1 & 5 \\
\hline & Amphora pediculus & 8 & 11 \\
\hline & Aneumastus pseudotuscula & -- & 3 \\
\hline & Caloneis molaris & -- & 2 \\
\hline & Caloneis schumanniana & -- & 1 \\
\hline & Cocconeis placentula & 9 & 11 \\
\hline & Cyclotella ocellata & 5 & -- \\
\hline & Cyclotella sp. & -- & 10 \\
\hline & Cyclotella sp. 2 & -- & 2 \\
\hline & Cymbella cistula & -- & 1 \\
\hline & Cymbella obscura & 1 & -- \\
\hline & Cymbella silesiaca & 1 & 7 \\
\hline & Cymbella sp. & 1 & -- \\
\hline & Cymbella subcuspidata & -- & 1 \\
\hline & Diadesmis laevissima & 1 & 4 \\
\hline & Diadesmis perpusilla & 11 & 11 \\
\hline & Diatoma vulgaris & 5 & -- \\
\hline & Diploneis ovalis & -- & 5 \\
\hline & Encyonema caespitosum & -- & 1 \\
\hline & Fragilaria capucina & 11 & -- \\
\hline & Fragilaria famelica & 6 & -- \\
\hline & Fragilaria pinnata & -- & 5 \\
\hline & Gomphoneis olivaceum & 9 & 1 \\
\hline & Gomphonema acuminatum & 1 & -- \\
\hline & Gomphonema angustatum & 11 & 6 \\
\hline & Gomphonema angustum & 10 & 7 \\
\hline & Gomphonema grovei & -- & 1 \\
\hline & Gomphonema parvulum & 2 & 6 \\
\hline & Gomphonema truncatum & 1 & 2 \\
\hline & Gyrosigma sp. & -- & 5 \\
\hline & Melosira sp. & -- & 1 \\
\hline & Meridion circulare & 8 & -- \\
\hline & Navicula angusta & 4 & -- \\
\hline & Navicula arvensis & 1 & -- \\
\hline & Navicula bryophila & -- & 1 \\
\hline & Navicula capitatoradiata & -- & 9 \\
\hline & Navicula cryptotenella & -- & 9 \\
\hline & Navicula fossalis & 1 & -- \\
\hline & Navicula goeppertiana & 1 & -- \\
\hline & Navicula gregaria & 11 & 4 \\
\hline & Navicula jentzschii & -- & 1 \\
\hline & Navicula margalithii & -- & 11 \\
\hline & Navicula medioconvexa & -- & 1 \\
\hline & Navicula minima & -- & 8 \\
\hline & Navicula subminuscula & 10 & 11 \\
\hline
\end{tabular}


Appendix 2. Periphyton taxa identified and the number of biological sampling sites where each taxa occurred in Johnson County, Kansas, streams during March and July 2007.—Continued

[Bacillariophyta, diatoms; Chlorophyta, green algae; Cyanophyta, blue-green algae or cyanobacteria; Euglenophyta, euglenoids; --, taxa did not occur]

\begin{tabular}{|c|c|c|c|}
\hline \multirow{2}{*}{ Division } & \multirow{2}{*}{ Taxa } & \multicolumn{2}{|c|}{ Site number } \\
\hline & & March & July \\
\hline & Navicula tenelloides & -- & 1 \\
\hline & Navicula trivialis & 6 & 5 \\
\hline & Navicula tuscula & 1 & -- \\
\hline & Navicula veneta & 10 & 5 \\
\hline & Nitzschia acicularis & 4 & 1 \\
\hline & Nitzschia acula & -- & 1 \\
\hline & Nitzschia amphibia & 3 & 11 \\
\hline & Nitzschia coarctata & 4 & 1 \\
\hline & Nitzschia constricta & -- & 6 \\
\hline & Nitzschia dissipata & 11 & 8 \\
\hline & Nitzschia dubia & 6 & -- \\
\hline & Nitzschia inconspicua & 11 & 11 \\
\hline & Nitzschia levidensis & -- & 2 \\
\hline & Nitzschia perminuta & 10 & 11 \\
\hline & Nitzschia vermicularis & 7 & -- \\
\hline & Pinnularia obscura & 2 & 1 \\
\hline & Pinnularia subcapitata & -- & 8 \\
\hline & Placoneis clementioides & -- & 3 \\
\hline & Placoneis placentula & -- & 1 \\
\hline & Planothidium lanceolata & 9 & 10 \\
\hline & Pleurosigma salinarum & -- & 1 \\
\hline & Psammothidium ventralis & -- & 1 \\
\hline & Sellaphora pupula & 4 & -- \\
\hline & Sellaphora sp. & 1 & -- \\
\hline & Stauroneis anceps & 1 & 1 \\
\hline & Stauroneis smithii & 1 & 1 \\
\hline & Stephanodiscus niagarae & -- & 2 \\
\hline & Stephanodiscus parvus & 3 & -- \\
\hline & Stephanodiscus sp. & 3 & -- \\
\hline & Surirella brebissonii & 11 & 4 \\
\hline & Surirella sp. & -- & 1 \\
\hline & Synedra familiaris & 1 & -- \\
\hline & Synedra ulna & 9 & 3 \\
\hline \multirow[t]{7}{*}{ Chlorophyta } & Cladophora glomerata & 5 & 8 \\
\hline & Cosmarium sp. & -- & 4 \\
\hline & Pediastrum simplex & -- & 1 \\
\hline & Pyramichlamys sp. & -- & 1 \\
\hline & Rhizoclonium fontanum & 1 & -- \\
\hline & Stichococcus subtilis & 1 & 3 \\
\hline & Ulothrix subtilissima & 8 & 3 \\
\hline \multirow[t]{4}{*}{ Cyanophyta } & Anabaena sp & -- & 1 \\
\hline & Chroococcus limneticus & -- & 1 \\
\hline & Lyngbya sp. & -- & 2 \\
\hline & Phormidium lividum & 4 & 2 \\
\hline Euglenophyta & Trachelomonas volvocina & 10 & 3 \\
\hline
\end{tabular}




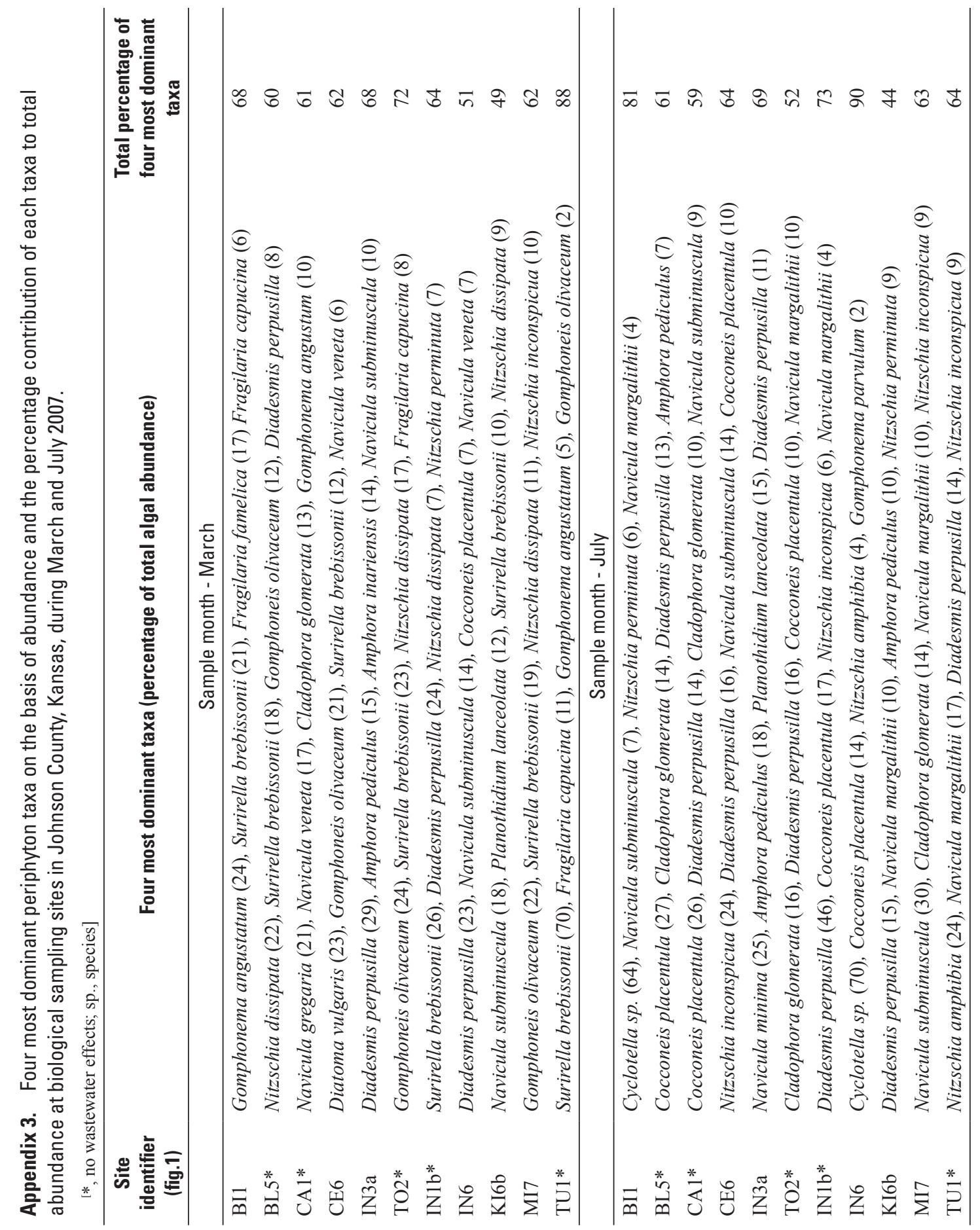




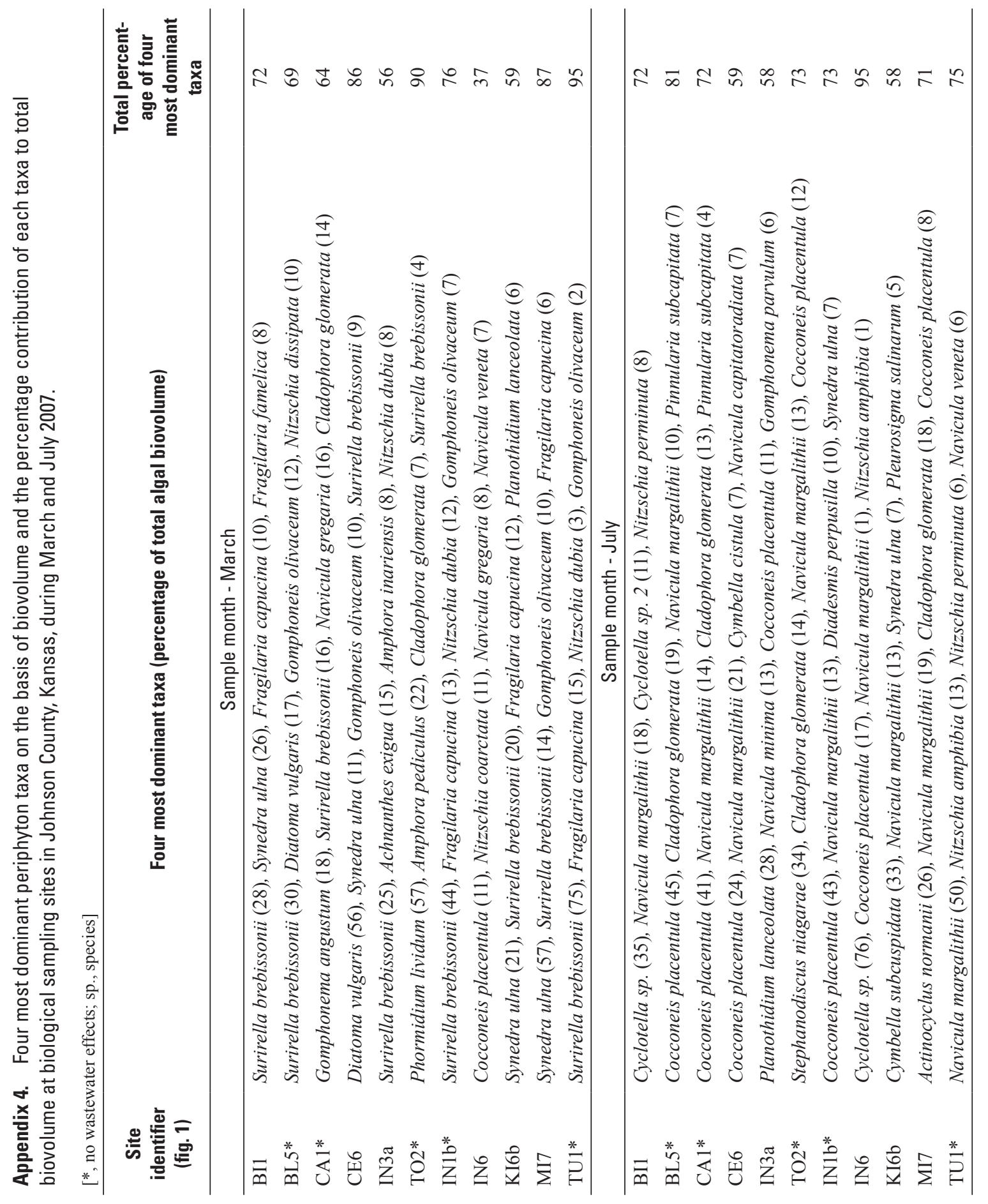


Appendix 5. Periphtyon metric scores calculated by the Algal Data Analysis Software (after Cuffney, 2003) for biological sampling sites in Johnson County, Kansas, during March and July 2007.

[All metrics were calculated using periphtyon biovolume. RA, relative abundance; *, no wastewater effects]

\begin{tabular}{|c|c|c|c|c|c|c|c|c|}
\hline $\begin{array}{c}\text { Site } \\
\text { identifier } \\
\text { (fig. 1) }\end{array}$ & $\begin{array}{c}\text { Algal } \\
\text { division } \\
\text { richness }\end{array}$ & $\begin{array}{c}\text { Taxa } \\
\text { richness }\end{array}$ & $\begin{array}{c}\text { RA } \\
\text { diatoms }\end{array}$ & $\begin{array}{c}\text { RA } \\
\text { dominant } \\
\text { diatom }\end{array}$ & $\begin{array}{l}\text { RA nitrogen- } \\
\text { heterotrophic } \\
\text { diatoms }\end{array}$ & $\begin{array}{c}\text { Siltation } \\
\text { index }\end{array}$ & $\begin{array}{l}\text { Shannon } \\
\text { diversity }\end{array}$ & $\begin{array}{c}\text { Bahls (1993) } \\
\text { pollution toler- } \\
\text { ance }\end{array}$ \\
\hline \multicolumn{9}{|c|}{ March } \\
\hline BI1 & 0.50 & 0.8 & 1.00 & 0.77 & 0.04 & 0.14 & 2.43 & 1.71 \\
\hline BL5* & 1.00 & .9 & .95 & .78 & .08 & .40 & 2.63 & 1.52 \\
\hline CA1* & 1.00 & 1.0 & .85 & .76 & .03 & .54 & 2.49 & 1.23 \\
\hline CE6 & .50 & .7 & 1.00 & .78 & .07 & .25 & 2.45 & 1.86 \\
\hline IN3a & 1.00 & .9 & .99 & .73 & .27 & .20 & 2.37 & 1.30 \\
\hline TO2* & 1.00 & .9 & .97 & .76 & .08 & .31 & 2.32 & 1.48 \\
\hline IN1b* & .75 & .9 & .98 & .74 & .11 & .23 & 2.43 & 1.52 \\
\hline IN6 & .75 & .9 & .96 & .78 & .25 & .44 & 2.69 & 1.32 \\
\hline KI6b & .50 & .8 & .98 & .84 & .27 & .46 & 2.57 & 1.63 \\
\hline MI7 & .75 & .8 & .99 & .80 & .13 & .26 & 2.42 & 1.60 \\
\hline TU1* & .75 & .7 & .99 & .29 & .04 & .08 & 1.26 & 1.43 \\
\hline \multicolumn{9}{|c|}{ July } \\
\hline BI1 & 0.75 & 0.7 & 0.99 & 0.37 & 0.52 & 0.27 & 1.57 & 1.58 \\
\hline BL5* & .50 & .7 & .85 & .75 & .11 & .18 & 2.15 & 1.33 \\
\hline CA1* & .50 & .8 & .90 & .77 & .15 & .23 & 2.29 & 1.31 \\
\hline CE6 & .75 & .6 & .95 & .77 & .58 & .56 & 2.44 & 1.54 \\
\hline IN3a & .25 & .5 & 1.00 & .79 & .36 & .33 & 2.25 & 1.72 \\
\hline TO2* & 1.00 & 1.0 & .85 & .83 & .31 & .38 & 2.70 & 1.15 \\
\hline IN1b* & 1.00 & .7 & .96 & .60 & .22 & .18 & 1.98 & 1.34 \\
\hline IN6 & .50 & .4 & 1.00 & .39 & .15 & .08 & 1.25 & 1.47 \\
\hline KI6b & .50 & 1.0 & 1.00 & .86 & .28 & .44 & 3.03 & 1.39 \\
\hline MI7 & 1.00 & .7 & .86 & .67 & .69 & .73 & 2.40 & 1.19 \\
\hline TU1* & .50 & .5 & 1.00 & .76 & .63 & .68 & 2.40 & 1.48 \\
\hline
\end{tabular}




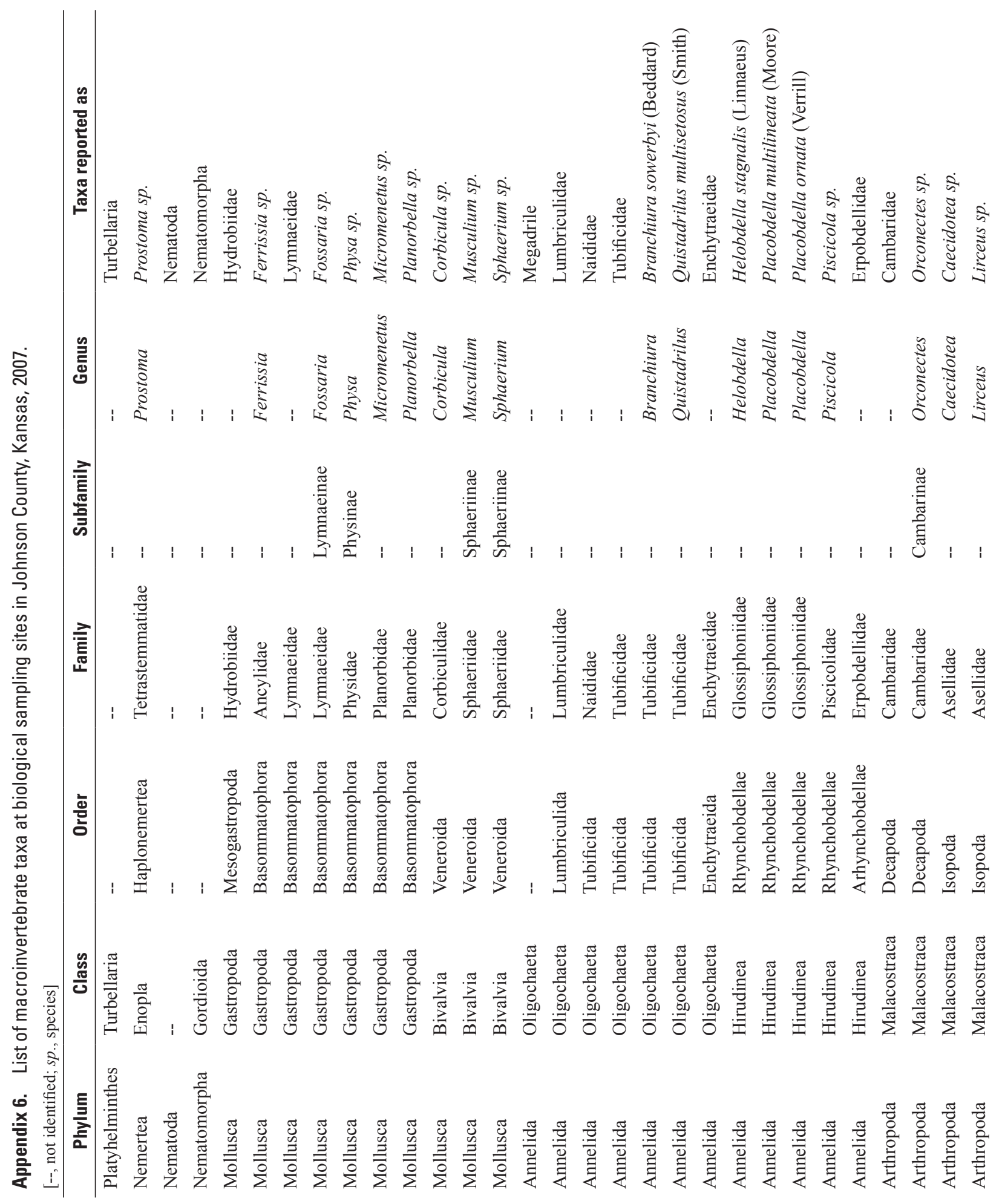




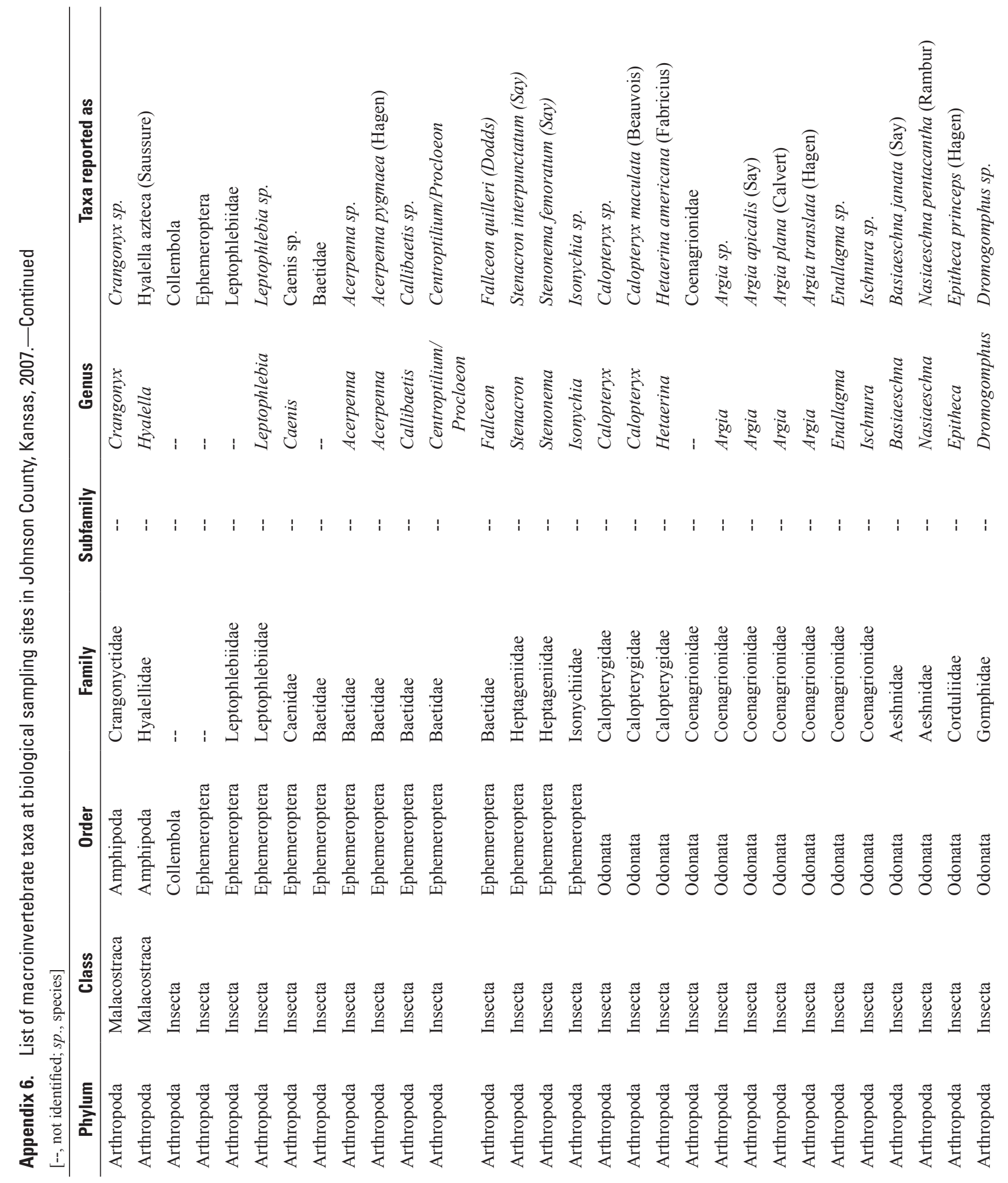




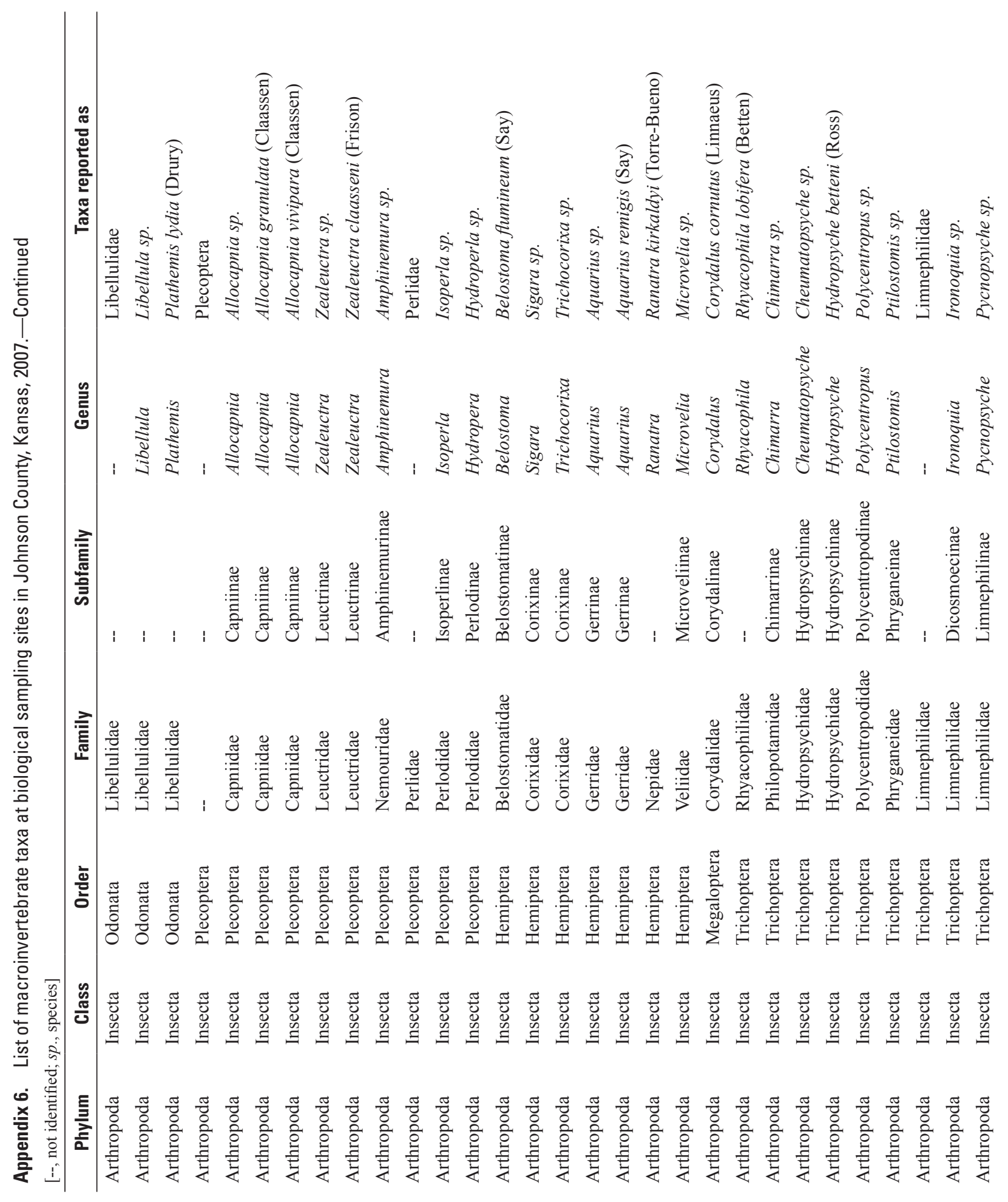




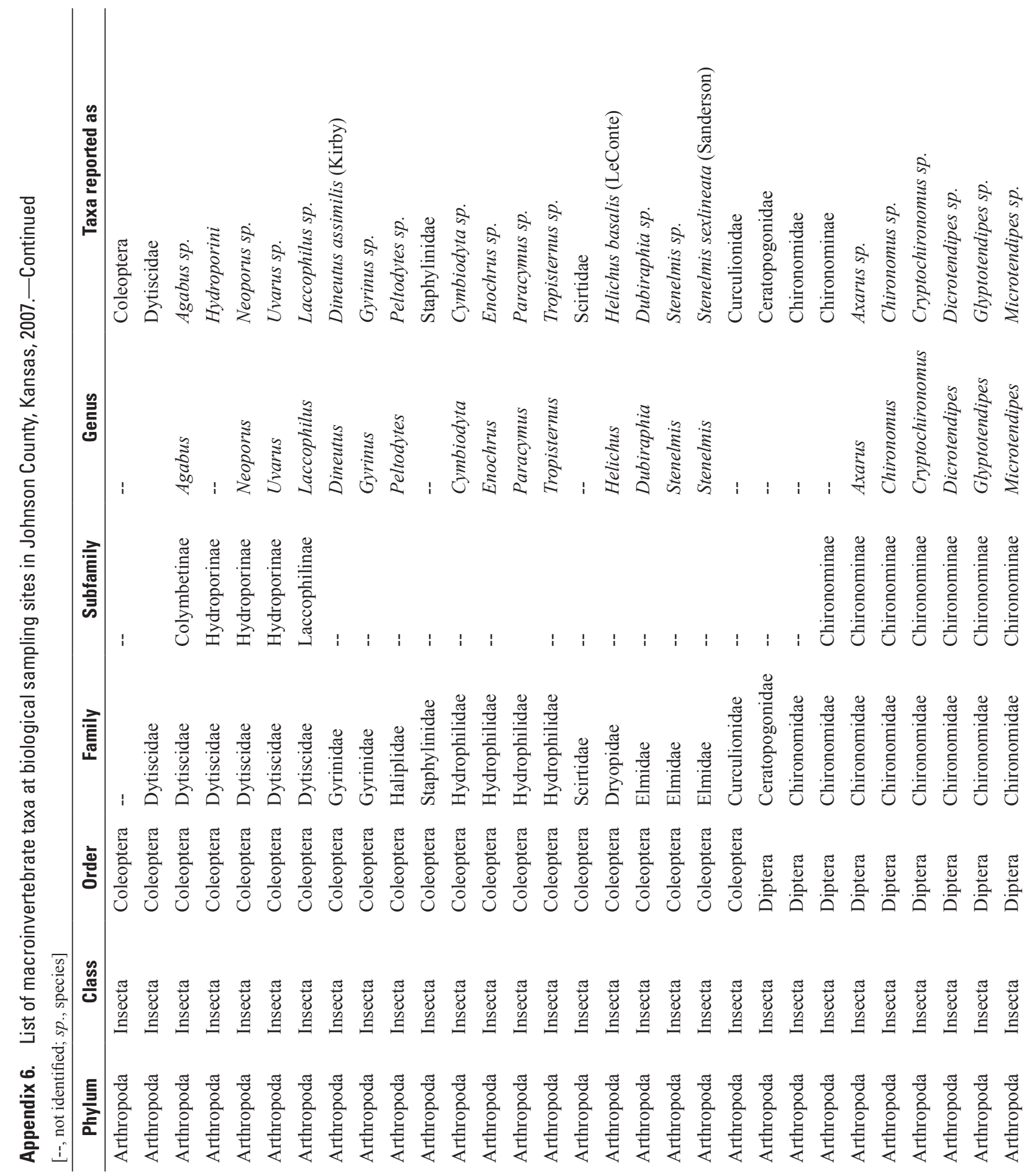




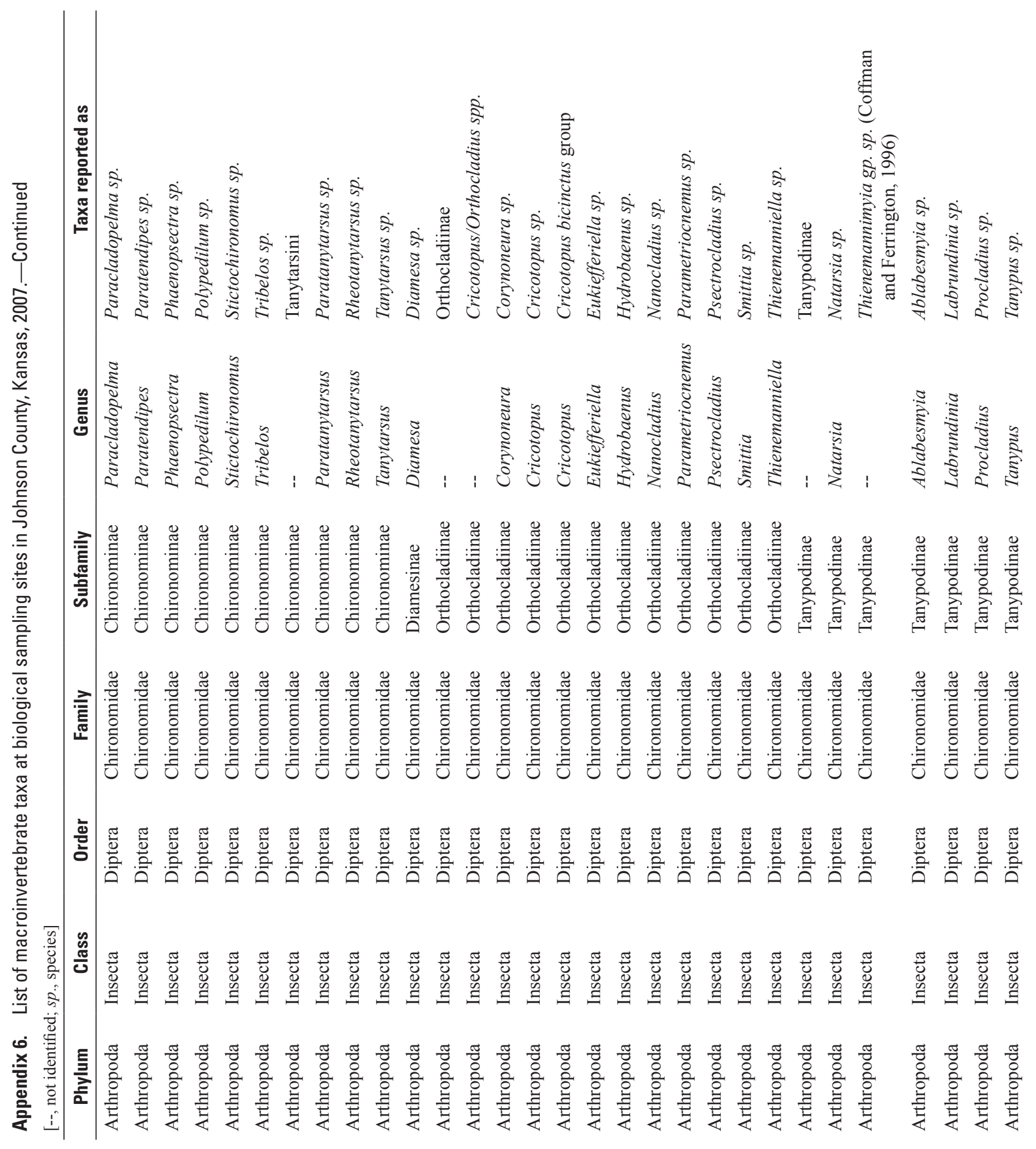


Appendices 1-7 83

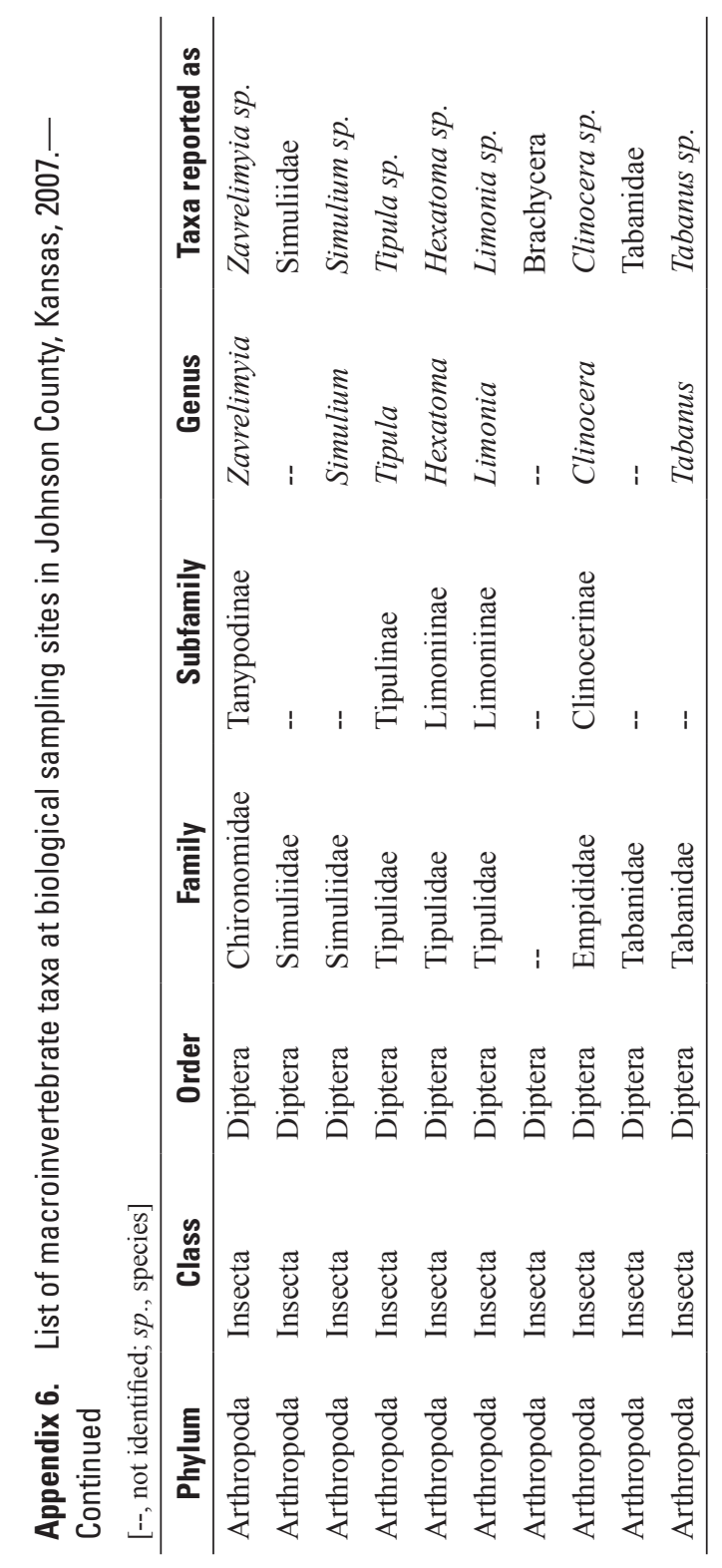




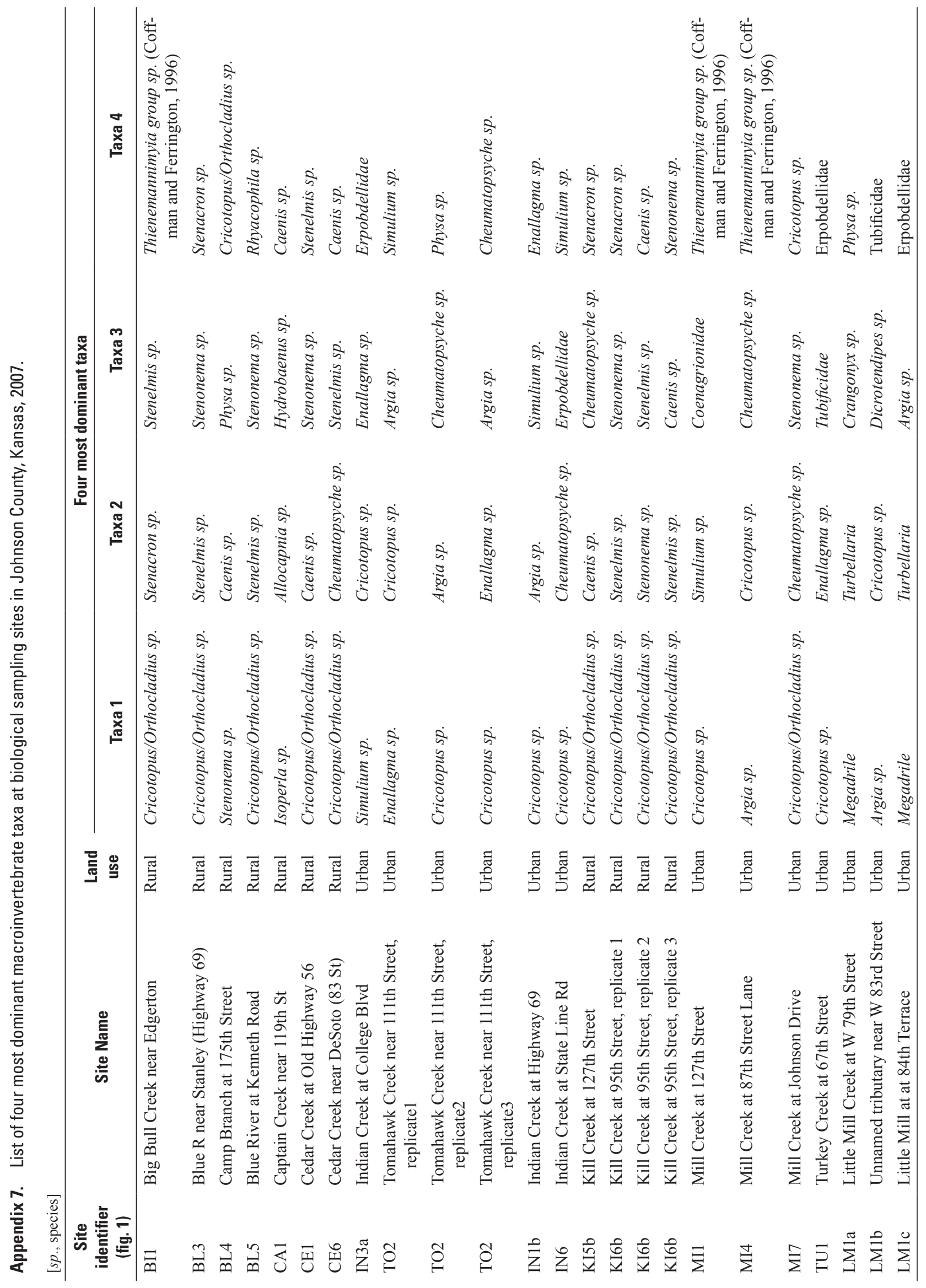


Publishing support provided by: Rolla Publishing Service Center

For additional information concerning this publication, contact: Director, USGS Kansas Water Science Center

4821 Quail Crest Place, Lawrence, KS (785) 842-9909

Or visit the Kansas Water Science Center Web Site at: http://ks.water.usgs.gov 

Back cover: Habitat assessment at Kill Creek at 127th Street, Johnson County, Kansas, September 2007, taken by Teresa Rasmussen, USGS, Lawrence, KS 

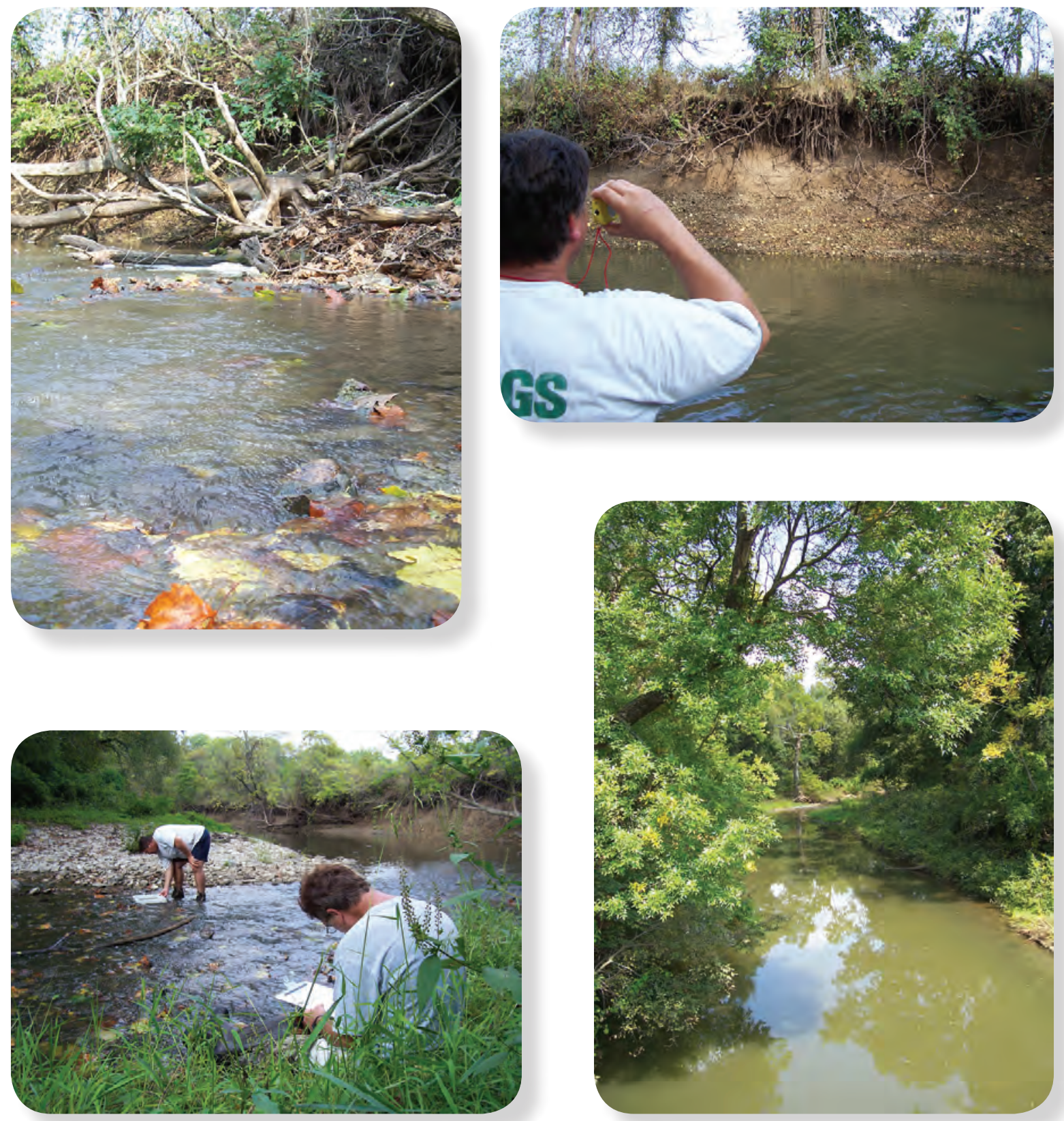

8 Printed on recycled paper

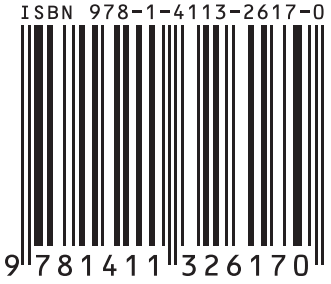

